\title{
'IN-TRANSITION'
}

\section{TOWARDS AN 'ETHOS OF SUSTENANCE' FOR OUR LADY SCHOOL}

\section{Melissa Nicole Stickl B.A.S.}

\author{
A THESIS SUBMITTED TO \\ THE FACUlTy OF GRADUATE STUdies \\ IN PARTIAL FULFILLMENT OF \\ THE REQUIREMENTS FOR THE DEGREE OF
}

\section{Master of Architecture}

CARLETON UNIVERSITY

OTTAWA, ONTARIO

2009 


\section{Abstract}

'In-Transition' Towards an 'Ethos of Sustenance' For Our Lady School illustrates a process to find value in the modest built heritage of Lowertown West Ottawa - 287 Cumberland Street - Our Lady School - currently in a threshold position between further decay and new life.

The site of Our Lady was first inhabited by the Grey Nuns of the Cross in the 1860s however the original stone structure was replaced by a two and a half storey brick and cast-iron school in 1904; the outer shell still remains today. From its inception to its closure in the early 1970s, in conjunction with St. Brigid's Roman Catholic Church, Our Lady was a cornerstone of activity and development, growth and sustenance for Lowertown West.

To garner prudence for the site, value is recognized in the particularity of the past, present and future through the historic and age-value of Lowertown West, use-value and potential re-use in interstitial arts and housing and the use of temporal collage as a process to cultivate an architectural interstice to rehabilitate the former school.

The result of this process reclaims an 'ethos of sustenance' Karsten Harries believes has been lost in building and dwelling. Here meaning, use and value is afforded to both the old and the new when placed in a dynamic dialogue to sustain and support cultural and social endeavors. 


\section{ACKNOWLEDGEMENTS}

To my thesis advisor Federica Goffi, thank you for helping me to stay focused on my goals. Your enthusiasm and eagerness to converse every Friday kept me inspired throughout the duration of this thesis.

To all my family and friends, thank you for your love and support and for listening to me when I needed to verbalize my thoughts. I have sincerely appreciated your patience. I will do my best to be systematic, methodical and progressive or, as Aristotle would say, theoretical, practical and productive.

To all those who have provided additional stories, support and guidance, especially the community of Lowertown West Ottawa, thank you for your kind help.

For all those who remain misrepresented and under appreciated, this thesis is for you.

Part of this thesis was presented at the 2009 Communication Graduate Caucus annual conference held by Carleton University in March. The theme for the Caucus this year was "World(s) In Transition: Perceptions and Interpretations."

Part of this thesis will be presented at the 2009 Heritage Canada Foundation annual conference in September. The theme for the conference this year is "The Heritage Imperative: Old Buildings in an Age of Environmental Crisis." 


\section{Contents}

LIST OF FIGURES V

List of Plates $\mathrm{x}$

Prologue 11

THE LOST ETHOS 11

The Present And the Allegory of Prudence 16

Sites 'In-Transition' 19

THE ROMAN PALIMPSEST 20

THE MARgINS OF BERLIN 26

'IN-TransITION' IN NORTH AMERICA 30

\section{LOCATING AN}

'Ethos Of Sustenance' 36 For OUR Lady School 38

I Collective Memory 40

AUTHOR-ITY

TO PRESERVE AND TO PROTECT

NEGATION AND RECONCILIATION

Cultural Sustenance:

IN MAIN STREETS

AND DOWNTOWNS

II Use-VAlue ANd Re-USE 65

EXHIBITED USE-VALUE

No USE-VALUE

Sustaining USE-VALUE IN RE-USE

SOCIAL SUSTENANCE:

THROUGH HOUSING

AND THE ARTS

III Temporal Collage 87

Collage as Design Process TEMPORAL USE

AND PHASED CONSTRUCTION

ArChiteCture as Process:

IN THE WORK OF MS \& R ARCHITECTS
I OF LOWERTOWN WEST 55

PEA SOUPS, JEWS AND DOGANS

ELISABETH BRUYERE AND

THE GREY NUNS OF THE CROSS

II In THE ARTS AND Housing 76

SAINT BRIGID AND SHEPHERDS

THE LOST AND THE Found

Musicians, PoEts, Photographers

III To Cultivate The Interstice 95

THE INTERSTICE

THE ARCHITECT

AND THE COMMUNITY

EPILOGUE 102

The Return of Prudence 102

THE FOUND ETHOS 104

BIBLIOGRAPHY 105

Plates 108

APPENDICES 124 


\section{LIST OF FIGURES}

(All IMAGES COPYRIGHT OF THE AUthor UNLESS OTHERWISE NOTED)

1. Waterford, Ontario, author's hometown c. 1900 from The Official Donnelly Home Page. June $2009<$ http://www.donnellys.com/Gallery.html> (June 2009). 8

2. Waterford, Ontario, author's hometown in 2009. 14

3. Suburban development near Markham, Ontario north of Toronto taken by Ian Duke in November of $2005 . \quad 14$

4. Allegory of Prudence, Titian, c. 1565-1570 from Erwin Panofsky, "Titian's Allegory of Prudence." In Meaning in the Visual Arts. (Chicago, IL: The University of Chicago Press, 1955), 146.16

5. Allegory of Music, Frontispiece of Franchinus Gaforius, Practica musice, Milan, 1496 from Erwin Panofsky, "Titian's Allegory of Prudence." In Meaning in the Visual Arts. (Chicago, IL: The University of Chicago Press, 1955), 158. 17

6. Threshold II, Jake Baddeley, 2004 from <http://www.jakebaddeley.com> (October 2008). 19

7. Janus Quadrifrons as in Rome Italy, Giovanni Battista Piranesi, mid-eighteenth century from Giovanni Battista Piranesi. Giovanni Battista Piranesi: the complete etchings. (San Francisco: Alan Wofsy, 1994), 114.19

8. The Archimedes Palimpsest, Parchment 64, $10^{\text {th }}$ century from Archimedes: The Palimpsest Project. $<$ http://www.archimedespalimpsest.org $>$ (May 2009). 20

9. The Church of San Clemente, ground plan of the ancient church and its smaller early Medieval successor. Pavement of the sixth century (after Guidobaldi), Rome, Italy from Hugo Brandenburg, Ancient Churches of Rome from the Fourth to the Seventh Century. Turnhout, (Belgium: Brepolis Publishers N.V., 2004), 295. 22

10. The site of the Church of San Clemente as built in layers beginning in the first century, Rome, Italy from Basilica San Clemente <http://www.basilicasanclemente.com> (May 2009). 22

11. The interior of the Church of San Clemente as it appears today in Rome, Italy from Hugo Brandenburg, Ancient Churches of Rome from the Fourth to the Seventh Century. Turnhout, (Belgium: Brepolis Publishers N.V., 2004), 144.22

12. Blurring in transitions in the tufa block at San Clemente, first century, Rome, Italy from Basilica San Clemente <http://www.basilicasanclemente.com> (May 2009). 23

13. View of the bridge from the Commune wall to the south, Carlo Scarpa, Museo di Castelvecchio, Verona, Italy from Richard Murphy, Carlo Scarpa and Castelvecchio. (Butterworth Architecture, 1990). 24

14. The Porta del Morbio during excavations, Museo di Castelvecchio, Verona, Italy from Richard Murphy, Carlo Scarpa and Castelvecchio. (Butterworth Architecture, 1990). 24

15. An early sketch of the Cangrande space at first-floor level, Carlo Scarpa, Museo di Castelvecchio, Verona, Italy from Richard Murphy, Carlo Scarpa and Castelvecchio. (Butterworth Architecture, 1990). 25

16. Axonometric of the Cangrande roof soffit from the southwest, Carlo Scarpa, Museo di Castelvecchio, Verona, Italy from Richard Murphy, Carlo Scarpa and Castelvecchio. (Butterworth Architecture, 1990). 25

17. Berlin, Germany from Spaces of Uncertainty. (Wuppertal: McColler und Busmann, 2002). 27

18. Berlin, Germany from Spaces of Uncertainty. (Wuppertal: McColler und Busmann, 2002). 27 
19. Cesare Cesariano's editon of Vitruvius' Ten Books on Architecture, 1521 from Vitruvius Pollio. De architectura. (Bronx: Blom, 1968-1521). 28

20. Aerial View showing the Halle, Glashaus, MS Hoppetosse and Swimming Barge with decks, Arena Berlin Treptow, Berlin, Germany from Urban Catalyst, "Patterns of the Unplanned." Loose Space: Possibility and Diversity in Urban Life. (Abingdon, Oxon,: Routledge, 2007), 276.29

21. Halle Exterior, Arena Berlin Treptow, Berlin, Germany from Arena Berlin. $<$ http://www.arena-berlin.de/> (May 2009). 30.

22. Arena Berlin Treptow Hall, Berlin, Germany from Arena Berlin. <http://www.arenaberlin.de/> (May 2009). 30

23. 1922 from Le Corbusier, The Radiant City. (New York, NY: The Orion Press, 1933), 202. 31

24. 1922 from Le Corbusier, The Radiant City. (New York, NY: The Orion Press, 1933), 203. 31

25. The Radiant City as proposed by Le Corbusier in 1933 from Le Corbusier, The Radiant City. (New York, NY: The Orion Press, 1933), 207. 31

26. The Radiant City in plan as proposed by Le Corbusier in 1933 from Le Corbusier, The Radiant City. (New York, NY: The Orion Press, 1933), 170. 32

27. Broadacre City as proposed by Frank Lloyd Wright in 1958 from Frank Lloyd Wright, The Living City. (New York, NY: Horizon Press, 1958), 66. 32

28. The North End, Boston, MA pre 1959 from William M. DeMarco. Ethics and Enclaves; Boston's Italian North End. (Ann Arbor, Michigan: U.M.I. Research P., 1981). 33

29. The North End, Boston, MA post 1959. 33

30. Villa Savoy before restoration, Poissy France, 1928-31 from David Leatherbarrow and Moshen Mostafavi, On Weathering. (Cambridge, MA: MIT Press, 1993), 7. 41

31. Villa Savoy after restoration, Poissy France, 1928-31 David Leatherbarrow and Moshen Mostafavi, On Weathering. (Cambridge, MA: MIT Press, 1993), 6. 41

32. Designating a Heritage Conservation District in the Province of Ontario from Heritage Conservation Districts: a guide to district designation under the Ontario Heritage Act. (Toronto, ON: Ministry of Culture, 2006), 17.45

33. Main Street Waterford, Ontario, author's hometown in 2009. 52

34. Perth, Ontario during Maplefest in April of 2002 from Heritage Canada Foundation, Main Street: Past and Present. March 2009. 53

35. Blairmore Main Street Alberta from Heritage Canada Foundation, Main Street: Past and Present. March 2009. 53

36. Plan of Bytown, 1842, Public Archives Canada from Michael McClelland, "Lowertown West Heritage Conservation District Study." May 1993, 37.55

37. Lowertown, View from the Parliament (NAC C25559), 1892 from Michael McClelland, "Lowertown West Heritage Conservation District Study." May 1993, 1. Refer to Plate 1 for larger image. 56

38. Lowertown West Urban Renewal Sketch for the corner of St. Patrick and Dalhousie Streets from Planning Branch, Department of Planning and Works, Urban Renewal: Ottawa, Canada. (Ottawa, Ontario: Corporation of the City of Ottawa, 1967), 125. 57

39. Lowertown West Urban Renewal Sketch for the corner of St. Patrick and Dalhousie Streets from Planning Branch, Department of Planning and Works, Urban Renewal: Ottawa, Canada. (Ottawa, Ontario: Corporation of the City of Ottawa, 1967), 125. 57

40. Boundary of the Byward Market Heritage Conservation District in 1990. (East/West Orientation), City of Ottawa By-Law. 58

41. Boundary of the Byward Market Heritage Conservation District in 1991. (East/ West Orientation), City of Ottawa By-Law. 58 
42. Boundary of the Lowertown West Heritage Conservation District in 1993. (North / South orientation), City of Ottawa By-Law. 59

43. Lowertown West, Public Archives Canada, 1843 from Michael McClelland, "Lowertown West Heritage Conservation District Study." May 1993, 38. 59

44. St. Bridget's School located at 233 Murray originally constructed in 1924 as the English speaking Catholic school for boys. Today, the school houses volunteer and support services for Shepherds of Good Hope. 60

45. Ecole Routhier located at 172 Guigues originally constructed in 1932. Today, the school operates as the Routhier Community Centre and is owned by the City of Ottawa. 60

46. Ecole Guigues located at 159 Murray was originally constructed in 1904. Today original architectural elements of the school have been restored and the building functions as a seniors residence. 61

47. Our Lady School, 287 Cumberland was originally constructed in 1904 as the English speaking Catholic school for girls. Today the school is abandoned and boarded. 61

48. Mere Élisabeth Bruyère c. 1850 from Michael Newton. Lower town Ottawa. Vol.1 (Ottawa, ON: National Capital Comission, 1979), 256. 62

49. Élisabeth Bruyère Hospital, 43 Bruyère Street, Lowertown West. 63

50. St. Brigid School, 200 Springfield Road in New Edinburgh. 63

51. The Cover of "From Abandonment to Affordable Housing," dated June 16, 2008, Abandonment Issues. 72

52. 52-54 Bolton St. resides within the Lowertown West HCD - its owner would like to have it demolished. 73

53. 78-80 Bolton St. resides within the Lowertown West HCD - its owner would like to have it demolished. 73

54. P.S.1 Institute of Contemporary Art, Long Island, NY from Kenneth Powell. Architecture Reborn: Converting Old Buildings For New Uses. (New York, NY: Calmann \& King Ltd., 1999), 101. 74

55. “Afterparty." by architecture firm MOS, 2009 Young Architects' Program Winning Entry, P.S.1 Institute of Contemporary Art, Long Island, NY from P.S.1 Contemporary Art Centre (MOMA). <http://ps1.org> (May 2009). 74

56. Former Wychwood Toronto Transit Corporation Repair Barns, an abandoned complex before being rehabilitated by Artscape, Toronto, ON from "Barns Photos." Artscape Wychwood Barns. <http://www.torontoartscape.on.ca/places-spaces/artscape-wychwoodbarns/barns-photos $>$ (May 2009). 75

57. Exterior Barn 2, Artscape Wychwood Barns, Toronto, ON from "Barns Photos." Artscape Wychwood Barns. <http://www.torontoartscape.on.ca/places-spaces/artscapewychwood-barns/barns-photos $>$ (May 2009). 75

58. Interior Barn, Artscape Wychwood Barns, Toronto, ON from "Barns Photos." Artscape Wychwood Barns. $<$ http://www.torontoartscape.on.ca/places-spaces/artscape-wychwoodbarns/barns-photos $>$ (May 2009). 75

59. Exterior Barn 2, Artscape Wychwood Barns, , Toronto, ON from "Barns Photos." Artscape Wychwood Barns. $<$ http://www.torontoartscape.on.ca/places-spaces/artscapewychwood-barns/barns-photos $>$ (May 2009). 75

60. Site Palimpsest: perceptions and use of the juncture between St. Patrick, Murray and Cumberland Streets today. 76

61. North façade, Saint Brigid's Centre for the Arts and Humanities, home of the National Irish Canadian Cultural Centre. 77

62. Interior facing south towards main alter, Saint Brigid's Centre for the Arts and Humanities, home of the National Irish Canadian Cultural Centre. 77

63. Concert Hall Plan, Saint Brigid's Centre for the Arts and Humanities, home of the National Irish Canadian Cultural Centre, Barry Padolsky Architects. 78 
64. Basement Plan, Saint Brigid's Centre for the Arts and Humanities, home of the National Irish Canadian Cultural Centre, Barry Padolsky Architects. 78

65. "An Irish Christmas" concert by Danu from Ireland as advertised in the Ottawa Citizen December 6, 2008. 79

66. 2008-2009 Concert by the University of Ottawa Orchestra, programme from April 3, 2009. 79

67. 2009 Writers Festival Programme; 2009 Writers Festival Programme featuring Michael Ignatieff April 24, 2009; Signature of Michael Ignatieff from book signing after presentation. 79

68. 2009 Writers Festival Programme; 2009 Writers Festival Programme featuring Michael Ignatieff April 24, 2009; Signature of Michael Ignatieff from book signing after presentation. 79

69. 2009 Writers Festival Programme; 2009 Writers Festival Programme featuring Michael Ignatieff April 24, 2009; Signature of Michael Ignatieff from book signing after presentation. 79

70. 233 Murray Street, former home of St. Bridget's School currently houses Volunteer and Support Services for Shepherds of Good Hope. 80

71. Soup Kitchen at 233 Murray Street serves nearly 400 meals per day. 80

72. The Emergency Shelter for Shepherds of Good Hope at 265 King Edward Avenue. 81

73. Emergency Shelter beds at 265 King Edward Avenue. 81

74. 287 Cumberland Street, proposed to be re-used as the Our Lady Community Art Centre. 81

75. 207-209 Murray Street, proposed to be re-used as the library and archive for the Our Lady Community Art Centre. 81

76. Site Collage with proposed uses for 287 Cumberland Street and 207-209 Murray Street, newspaper articles and headlines from the Ottawa Citizen 2009. 82

77. Operation Come Home Cactus Youth Centre located at 179 Murray Street. The home is the former church rectory for St. Brigid's Roman Catholic Church. 83

78. 281-83 Cumberland Street, proposed to be re-used as live/work spaces for OCH youth. 84

79. Site Collage with proposed uses for 281-83 Cumberland Street, newspaper articles and headlines from the Ottawa Citizen 2009. 84

80. 306 Cumberland, La Petite Mort Gallery taken by Tony Fouhse. 85

81. 306 Cumberland, La Petite Mort Gallery taken by Tony Fouhse. 85

82. 238 Dalhousie, Canteen. 85

83. 320 St. Patrick, proposed to be re-used as studio space for interstitial artists. 85

84. Site collage with proposed uses for 320 St. Patrick Street, newspaper articles and headlines from the Ottawa Citizen 2009. 86

85. 324 St. Patrick, proposed for future construction of a gallery to display the work of interstitial artists at 320 St. Patrick. 86

86. A tribute to Marilyn, Mimmo Rotella, c. 1960 from Brandon, Taylor, Urban Walls: a generation of collage in Europe \& America. (New York, NY: Hudson Hills Press, 2008). 87

87. Les dessous du quai de la Rapée, Jacques de la Villegle, 1962 from Brandon, Taylor, Urban Walls: a generation of collage in Europe \& America. (New York, NY: Hudson Hills Press, 2008). 88

88. Temporary, Mark Bradford, 2005. (Note: the original image has been rotated 90 degrees clockwise) A layered image of how Bradford sees the city of Los Angles from Carter E. Foster, Neither New Nor Correct: New Work by Mark Bradford. (New York, NY: Whitney Museum of American Art, 2007). 88 
89. Central Staircase, Open Book, Minneapolis, MN, MS\&R Architects from Minnesota Centre for Reading, Writing and Book Arts. <http://www.openbookmn.org> (July 2009). 94

90. Open Book, Minneapolis, MN, MS\&R Architects from Minnesota Centre for Reading, Writing and Book Arts. $<$ http://www.openbookmn.org $>$ (July 2009). 94

91. Open Book, Minneapolis, MN, MS\&R Architects from Minnesota Centre for Reading, Writing and Book Arts. <http://www.openbookmn.org> (July 2009). 94

92. West Elevation of Our Lady Community Art Centre, Live / Work Residence for OCH Youth and Artist Studios, originally drawn at 1:100 scale. Refer to Plate 4. 95

93. Basement Plan, originally drawn at 1:100 scale. Refer to Plate 5. 96

94. Ground Floor Plan, originally drawn at 1:100 scale. Refer to Plate 6. 96

95. Interstice Floor Plan emphasizing the imagery of the Saint Brigid Cross, originally drawn at $1: 100$ scale. Refer to Plate 7.96

96. Second Floor Plan, originally drawn at 1:100 scale. Refer to Plate 8.96

97. Detail of connection between existing cast-iron columns and new steel i-beams. 97

98. Detail of connection between existing masonry shell and new interior walls. 97

99. Detail of connection between new wood rafters and new wood trusses. 97

100. Cross of Saint Brigid. 98

101. Cross of Saint Brigid in Plan. 98

102. The Minehan House Foundations as re-purposed for a new gallery space. 98

103. North / South Section emphasizing the connection between the existing school building and the new interstitial space, originally drawn at 1:100 scale. Refer to Plate 9.99

104. Initial Site Plan Sketch, November 2008. 99

105. Invitation for the reception to follow the defense of this thesis on August 24, 2009 between 3:00 and 4:00 PM. Refer to Plate 16. 101

106. Thesis defense at Saint Brigid's, August 24, 2009. 101

107. Thesis defense at Saint Brigid's, August 24, 2009. (Professor Federica Goffi, Dr. Claudine Deom, Professor Sheryl Boyle, Dr. Stephen Fai) 101 


\section{List OF Plates}

(All IMAges Copyright of THE AUthor UnLESS OTHERWISE NOTED)

1. Lowertown, View from the Parliament (NAC C25559), 1892 from Michael McClelland, "Lowertown West Heritage Conservation District Study." May 1993, 1.

2. Site Palimpsest: perceptions and use of the juncture between St. Patrick, Murray and Cumberland Streets today.

3. Site Proposal Collage: potential use for the juncture between St. Patrick, Murray and Cumberland Streets.

4. West Elevation of Our Lady Community Art Centre, Live / Work Residence for OCH Youth and Artist Studios, originally drawn at 1:100 scale.

5. Basement Plan, originally drawn at 1:100 scale.

6. Ground Floor Plan, originally drawn at 1:100 scale.

7. Interstice Floor Plan emphasizing the imagery of the Saint Brigid Cross, originally drawn at 1:100 scale.

8. Second Floor Plan, originally drawn at 1:100 scale.

9. North / South Section emphasizing the connection between the existing school building and the new interstitial space, originally drawn at 1:100 scale.

10. South Elevation of Our Lady Community Art Centre, originally drawn at 1:100 scale.

11. Site Model from above, originally constructed at 1:100 scale.

12. Site Model from above, featuring the West Elevation, originally constructed at 1:100 scale.

13. Site Model main entrance on West Elevation, originally constructed at 1:100 scale.

14. Site Model from above, featuring the North Elevation, originally constructed at 1:100 scale.

15. Site Model base, Ottawa Citizen newspaper articles and weathered plywood door from a tobacco stick kiln in Southwestern Ontario.

16. Invitation for the reception to follow the defense of this thesis on August 24, 2009 between 3:00 and 4:00 PM. 


\section{Prologue}

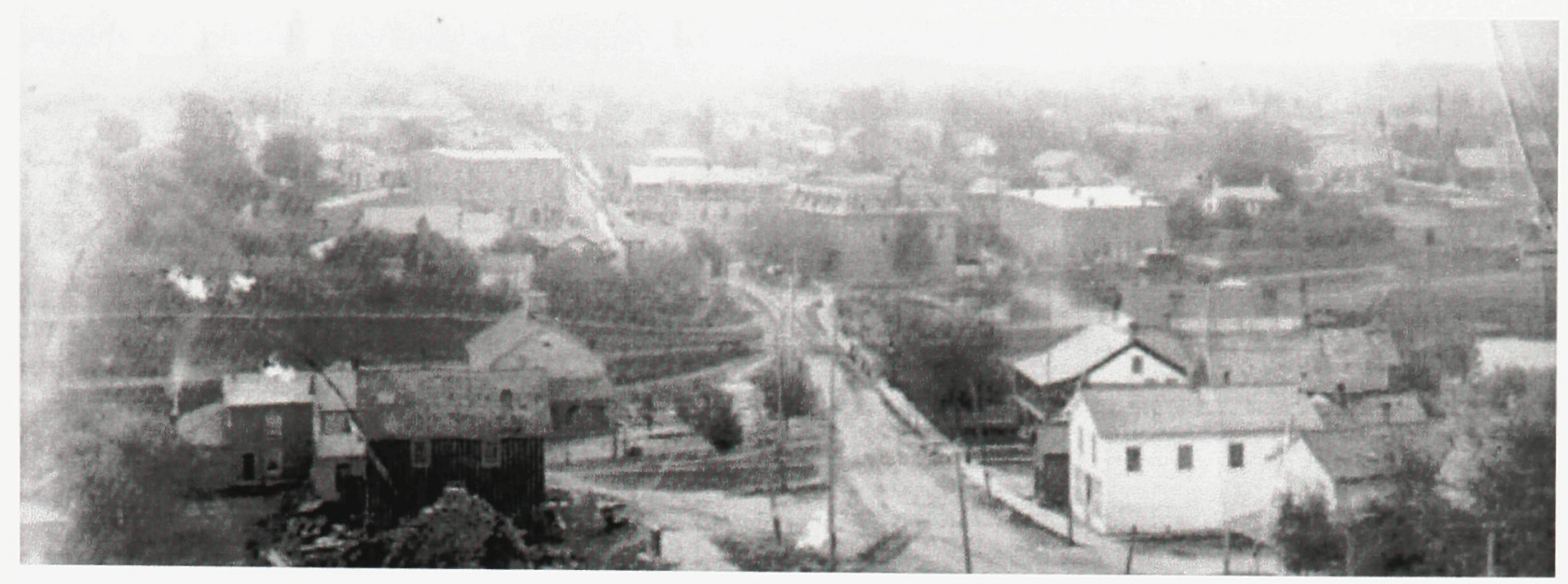

FIGURE 1: Waterford, Ontario, author's hometown c. 1900.

\section{THE LOST ETHOS}

When all places count the same we cannot place ourselves and become displaced persons. The ease with which we relocate ourselves and replace our buildings is witness to this displacement. - Karsten Harries

In The Ethical Function of Architecture, Karsten Harries claims "from the very beginning[,] architecture has had an ethical function, helping to articulate and even to establish man's ethos" but that an ethos that makes a "genuine dwelling" possible has generally been lost in the practice of architecture since as far back as the Enlightenment. ${ }^{1}$

The Greek term ethos refers to "the characteristic spirit or attitudes of a community, people or system, or of a literary work." While this translation reflects contemporary use of

\footnotetext{
${ }^{1}$ Harries originally made this claim during the oil crisis of the late 1970 s - a time of considerable change and questioning, and not only within the field of architecture. Harries has continued to re-propose his theory ever since. One can still reapply his sentiments now, over thirty years later. In 1997 Karsten Harries published a book with the same title as his essay of 1975: The Ethical Function of Architecture. Karsten Harries, "The Ethical Function of Architecture." Journal of Architectural Education. Vol. 29. No. 1. Humanist Issues in Architecture. 1975, 14.
}

${ }^{2}$ The Concise Oxford Dictionary. $9^{\text {th }}$ ed., 1995. "ethos." 
the term as zeitgeist, for Aristotle, ethos was associated with an ethical function. For Aristotle, ethos was one of the three strands of pisteis [methods of persuasion], intertwined with logos and pathos. ${ }^{3}$ Whereas logos and pathos referenced the logical and emotional appeals of a discussion, ethos stood for moral character which was "neither singular nor innate; ... a combination of practical wisdom, virtue, and good will and ... reflected in deliberate choices of actions and developed into a habit of mind." ${ }^{4}$ Even today, a writer will use the ethical function of their ethos as a literary device to convince readers of validity in arguments and to claim authorship over a body of work. ${ }^{5}$

The "lost ethos" Harries references in his writing is what it means to dwell, as described by Martin Heidegger in Building Dwelling Thinking. Here Heidegger explains that dwelling not only references a presence on the earth but also the manner in which this presencing ought to take place.

The way in which you are and I am, the manner in which we humans are on the earth, is Buan, dwelling. To be a human being means to be on the earth as a mortal. It means to dwell. The old word bauen, which says that man is insofar as he dwells, this word bauen however also means at the same time to cherish and protect, to preserve and care for, specifically to till the soil, to cultivate the vine. ${ }^{6}$

Heidegger's reference to the old word bauen emphasizes the nature of dwelling genuinely, necessarily supported by the presencing mentioned above. Where the old word bauen

\footnotetext{
${ }^{3}$ Nedra Reynolds, "Ethos as Location: New Sites for Understanding Discursive Authority." Rhetoric Review, Vol. 11. No. 2 Spring, 1993, 327. - Aristotle, On Rhetoric, 21.

${ }^{4}$ Ibid.

${ }^{5}$ In "Ethos as Location: New Sites for Understanding Discursive Authority," Nedra Reynolds proposes the feminist literary discourse of authors such as bell hooks is authoritative based on how ethos is attributed to a particular location.

${ }^{6}$ Martin Heidegger, "Building Dwelling Thinking" In Poetry, Language, Thought. (New York, NY: Harper \& Row, Publishers, 1971), 147.
} 
means "to cherish and protect, to preserve and care for, specifically to till the soil, to cultivate the vine," to dwell genuinely then is the means of providing sustenance for the mind and body through the physical realm of architecture. From Heidegger's explanation of bauen, one can deduce that genuine dwelling is only possible through an 'ethos of sustenance. $^{7}$

Harries believes this ethos has been lost in the practice of architecture since as far back as the Enlightenment, and refers often to Heidegger's description of the Black Forest farmhouse - a time and place removed from modern technology where "the self-sufficiency of the power to let earth and heaven, divinities and mortals enter in simple oneness into things ordered the house." ${ }^{8}$ While it is realized what it means to dwell has been challenged since the development of modern technology, this thesis gives emphasis to the separation between building and thinking in North America since the postwar period. ${ }^{9}$

Efforts to provide equal and adequate living and working opportunities and conditions for all North Americans, since the second world war, have largely resulted in an objective approach to design and construction which has allowed and encouraged standardization through national housing programs, building codes, urban and rural planning policies, heritage guidelines, even new sustainability rating systems

\footnotetext{
${ }^{7}$ Sustenance is defined as the act of sustaining and the supporting of life and of health. Henceforth, to sustain is to "give strength to; encourage, support, give nourishment." The Concise Oxford Dictionary. $9^{\text {th }}$ ed., 1995. "sustenance."

${ }^{8}$ Martin Heidegger, 160.

${ }^{9}$ It was during this period that Martin Heidegger first delivered his lecture "Building Dwelling Thinking" to an audience of architects. In the wake of World War II, Germany was suffering from a severe housing shortage and Heidegger was questioning what it means to dwell as opposed to what it means to have shelter. Karsten Harries, The Ethical Function of Architecture. 162.
} 
such as LEED (Leadership in Energy and Environmental Design as implemented by the Canadian Green Building Council). Although this standardization justly enforces quality controls of a quantifiable manner, it also encourages an architecture of homogeneity that disregards the particularity of place. Harries insists this "high degree of inter-changeability and uniformity is part of our technological culture, which insists not so much on dwellings as on machines for working and living." 10 There is no question standardization promotes concern for measurable economic and energy performance of buildings; however, less concern is cultivated for the prolonged and sustaining value of architecture as cultural artefact, embedded with both quantitative and qualitative knowledge.

Today, this standardization allows new urban infill, the suburban dwelling (shelter) and the big box store to act as objects in urban and rural landscapes with little reference to the previous and current conditions, and future potential of a particular place. (FIgure 2 \& 3) According to Kevin Lynch, "our new suburbs and new towns ... seem all begun yesterday and completely finished then. There is no crevice through which one can venture back or forward." 11 The homogeneity of the new North American town and suburb disregards the particularity of place to such a degree that Karsten Harries insists individuals become displaced, lacking connection to any specific physical place. As a result, relocation and replacement come with ease. Harries admits "the reward of this displacement is a new freedom, [but] its price [is] a new homelessness"- a new placelessness "render[ing] man's place arbitrary.",12

\footnotetext{
${ }^{10}$ Karsten Harries, "The Ethical Function of Architecture.” 14.

${ }^{11}$ Kevin Lynch, What Time is This Place? (Cambridge, MA: MIT Press, 1972), 61.

${ }^{12}$ Karsten Harries, "The Ethical Function of Architecture." 14
}

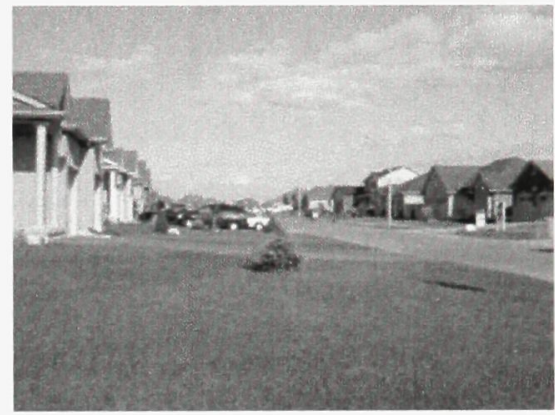

FIGURE 2: Waterford, Ontario, author's hometown in 2009 .

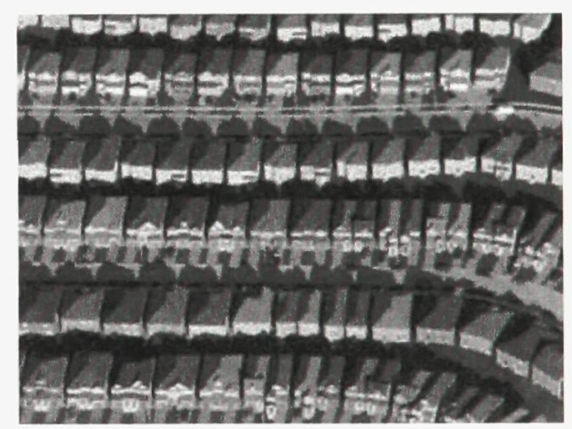

FIGURE 3: Suburban development near Markham, Ontario north of Toronto in 2005 
Site, client, program and production process are rarely the subject of investigation or radical transformation says Mary McLeod, ${ }^{13}$ yet they are necessary considerations to render the lost ethos found. Harries argues

only when we cease to consider the physical environment as material to be manipulated and controlled, but open ourselves to [a] natural language of place and time will we receive hints which may lead to a re-establishment of the lost ethos, of environments which will make a genuine dwelling possible. ${ }^{14}$

It is thus the responsibility of the architect to rediscover this "natural language" Harries further identifies as the essence of neighbourhoods and of regions. ${ }^{15}$ Through the storia composed by the architect, in a direct dynamic dialogue with a community, the genuine dwelling is not only found, it is sustained. $^{16}$ In this way, an 'ethos of sustenance' gives meaning to the past and potential for the future through particular values in the present as provided by their place.

\footnotetext{
${ }^{13}$ Mary McLeod, "Architecture and Politics in the Reagan Era: From Postmodernism to Deconstructivism." Assemblage. No. 8. Feb. 1989, 45.

${ }^{14}$ Karsten Harries, "The Ethical Function of Architecture." 14.

${ }^{15}$ Ibid

${ }^{16}$ Storia is used in reference to "Architecture as Embodied Knowledge" by Alberto Perez-Gomez. Perez-Gomez insists, the modern emphasis on shelter over dwelling has clouded the real issues. In order to posit a symbolic order, the architect needs to have his or her own storia, the history-theory which is not a method but rather a new mythos, an understanding of the meaning of the architect's actions "here and now" in relation to the totality of culture. Alberto Perez-Gomez, "Architecture as Embodied Knowledge." Journal of Architectural Education. Vol. 40. No. 2. Jubilee Issue, 1987, 57.
} 


\section{The Present and The Allegory of Prudence}

From the past the man of the present acts prudently so as not to imperil the future. - Titian

In the Renaissance, the present was visually represented in art as a time of prudence (defined today as "the quality or act of being prudent; caution with regard to practical matters; discretion; provident care in the management of resources; economy; frugality)." ${ }^{\prime 17}$ In each representation of prudence as a virtue (Allegory of Prudence), the present invisible third face of Janus was intimately connected to its past and future faces to create a tricephalous image. ${ }^{18}$ (FIGURE 4) First seen as the companion of Serapis in Hellenistic Alexandria, one of the best known representations of prudence is Titian's allegory in Venice, which displays an anthropomorphic triad in relation to a zoomorphic one. In his analysis of Titian's painting, Erwin Panofsky suggests one is to connect these three faces with

the three psychological faculties in the combined exercise of which this virtue consists: memory, which remembers, and learns from, the past; intelligence, which judges of, and acts in, the present; and foresight, which anticipates, and provides for or against, the future. ${ }^{19}$

In relation to the zoomorphic triad provided by Titian,

Panofsky further explains

the lion's head thus denotes the present, the condition of which between the past and the future, is strong and fervent by virtue of present action; the past is designated by the wolf's head because the memory of things that belong to the past is devoured and carried away; and the image of the dog trying to please, signifies the outcome of the future, of which hope, though uncertain, always gives us a pleasing picture. ${ }^{20}$

\footnotetext{
${ }^{17}$ The Concise Oxford Dictionary. $9^{\text {th }}$ ed., 1995. "prudence."

${ }^{18}$ Janus is the Roman god of doors and gateways most commonly depicted with two faces, one looking to the past and one looking to the future. The third face of Janus is invisible as the present is virtually impossible to capture.

${ }^{19}$ Erwin Panofsky, "Titian's Allegory of Prudence." In Meaning in the Visual Arts. (Chicago, IL: The University of Chicago Press, 1955), 149

${ }^{20}$ Ibid, 153.
}

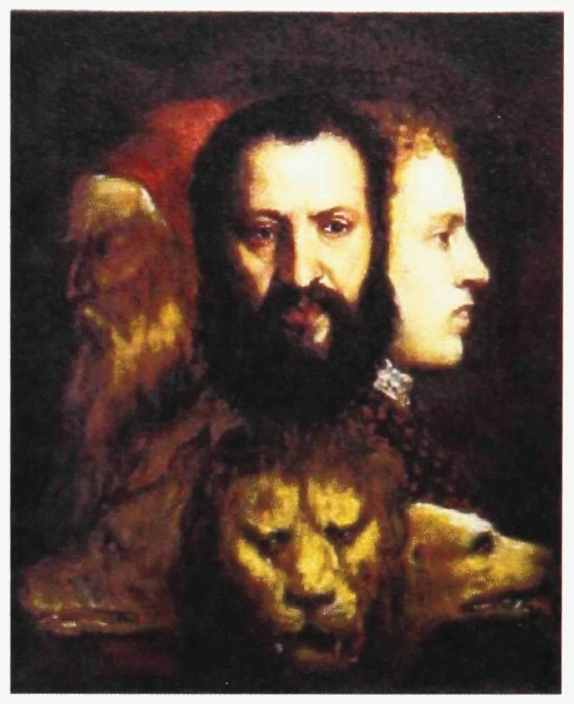

FIGURE 4: Allegory of Prudence, Titian, c. 1565-1570. 
Although one may disagree with the specific zoomorphic imagery Titian provides and thus the explanation Panofsky gives, one cannot deny the underlying metaphor offered by the allegory; the three tenses of past, present and future are intimately connected and need to be simultaneously acknowledged to garner prudence and integrity. In fact, in Medieval representations of prudence, dated prior to Titian's allegory, the wolf, lion and dog were intimately connected by a serpent or snake. This is noted in the text of Petrarch from 1338, where the image of Serapis is replaced by that of Apollo, who is accompanied by

a horrifying monster the body of which was like that of a serpent (corpus serpentinum); and it had three heads, to wit, that of a dog, a wolf and a lion, which though separated from each other, converged in one single body having only one snake tail. ${ }^{21}$ (FIGURE 5)

In this image, the "time serpent" takes on the persona of genius loci, the spirit of place, where loci refers to the Greek locus meaning place or location. The genius loci thus binds together the past, the present and the future to provide prudence at a particular place.

The myth of the tricephalous bound helps to identify and to articulate an 'ethos of sustenance.' By considering all three faces, change can occur while respecting the present value of the site and its image. It is thus the connection between each face, tense, that allows the genius loci to be seen as more than a fixed image of the site. ${ }^{22}$ The present is always changing and in a state of flux as it draws upon what has come before and what has yet to come.

\footnotetext{
${ }^{21}$ Ibid, 157

${ }^{22}$ The writings of Christian Norberg-Schultz suggest the genius loci of a site is an eternal image. By affirming that what not even time can cancel is the genius loci, I want to underscore that every place possesses its own peculiar identity and that is the proper task of man to comprehend that identity and take care of it, through a process that evidently will never come to an end. Christian Norberg-Schultz, Architecture: Presence, Language, Place. (Milano, Italy: Skira, 2000) , 55.
}

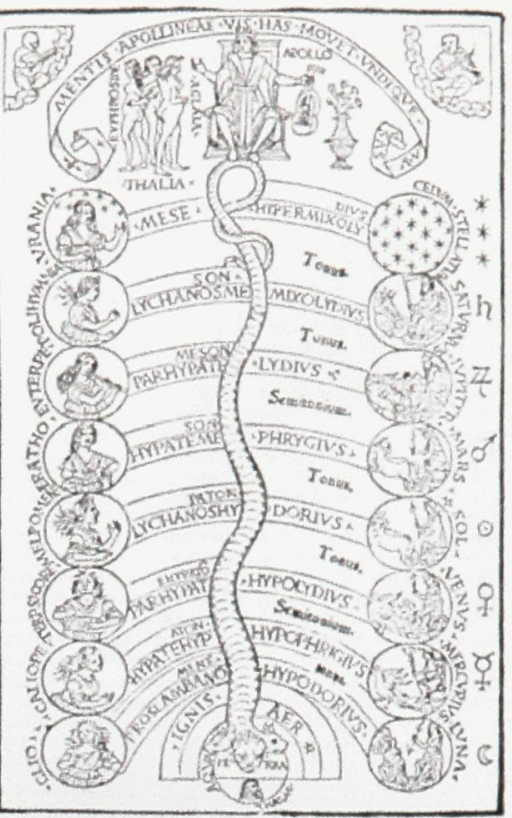

FIGURE 5: Allegory of Music. Frontispiece of Franchinus Gaforius, Practica musice, Milan, 1496. Here the corpus serpentinum extends, throughout the eight celestial spheres, from the feet of Apollo down to silent earth. 
Conscious in the present, it is this moment of transition that links the past and future together to sustain an 'ethos of sustenance.' 'In-transition,' this moment of present consciousness challenges modes of representation and interpretation and supports meaning and value in memory, intelligence and foresight. 


\section{Sites 'IN-Transition'}

There is a special poignancy in the moment of transition, which has its analogue in the pleasure of lingering in a doorway, the transition between spaces. The coming of the Midwestern spring, the setting of the sun, the turning of the leaves in New England, the arrival of the first heavy snow, all heighten the sense of the passage of time. - Kevin Lynch

What does it mean to be 'in-transition?' If one is in a space or a place or a specific time, one acknowledges inclusion among specific elements; and if one is 'in-transition' / intransit / in-movement / in-change, one is within the boundaries of a specific event between spaces, places and times. (FIGURE 6)

Sites 'in-transition' are thresholds acting as hinge points between architectural elements, spaces and realms and absorb the tension that exists between them. As specific points of transition between elements, commonly in opposition, thresholds denote a change in condition from that previously perceived. At the scale of the architectural project, a door connects an exterior and an interior space; a gate extends from a public street to a private courtyard; a cornerstone joins adjacent walls within a structure; a keystone bridges two halves of an arch over an entrance and a lintel denotes the presence of a gateway and carries the load over an opening. (FIGURE 7) At the scale of the city, rural agricultural land is developed due to population growth; rural and urban areas are redesigned and reconstructed in the aftermath of a war or a natural disaster and existing buildings rural and urban, with historical, architectural and use value are threatened with demolition due to specific socio-political conditions.

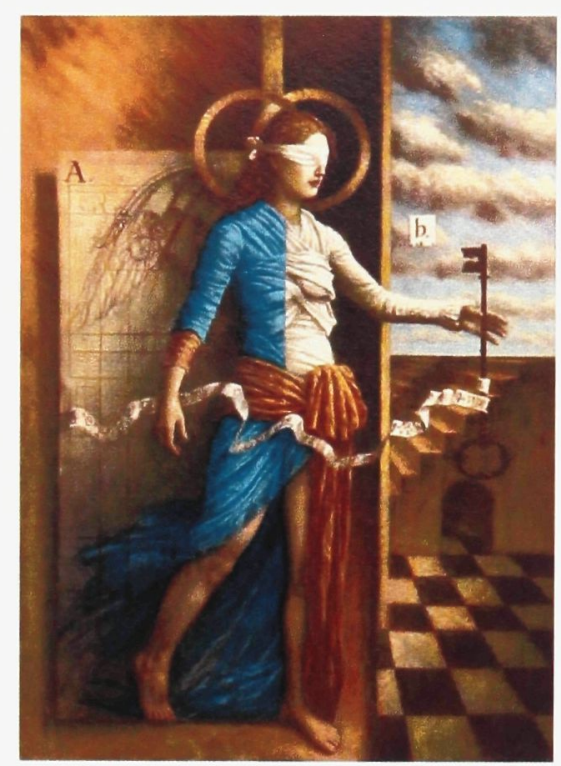

FIGURE 6: Threshold III, Jake Baddeley, 2004.

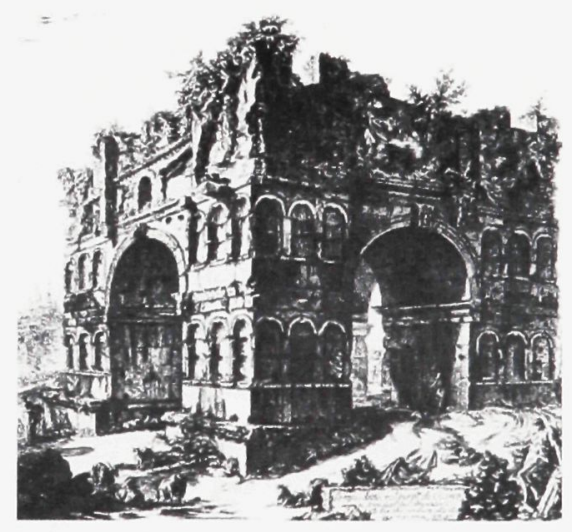

FIGURE 7: Janus Quadrifrons as in Rome Italy, Giovanni Battista Piranesi, mideighteenth century. 
For this thesis, attention is given to those existing buildings currently at the threshold between death and new life. 'Intransition' / in-transit / in-movement / in-change: these sites require adaptation to remain viable in the present.

Efforts to reuse and to adapt existing buildings when an original function has been abandoned for cultural, environmental, social, economic, political reasoning have been made since the inception of architecture. Yet it is the ethos and commitment of a community to its existing building stock that determines if and how sites 'in-transition' could again hold an ethical function. The following sections illustrate how existing buildings have been reused and adapted in form and meaning specific to their sites (places and times).

\section{The Roman Palimpsest}

From what vantage point can one operate a deconstruction of the past - a past solidified into an architectural or an urbanistic configuration, a past which becomes visible only when top layers are erased? - Keala Jane Jewell

In literature, palimpsests are recognized as "pieces of writing material or manuscripts on which later writings have written over the effaced original writings."1 During the Renaissance, the Romans wrote on vellum and parchment that could be erased and reused, presumably due to shortages in writing materials, however the original intention and execution of the palimpsest remains a point of debate between scholars. ${ }^{2}$ Probably the best known representation of the palimpsest is The Archimedes Palimpsest as layered in the twelfth century with the mathematical treatises of Archimedes, on an erased

\footnotetext{
${ }^{1}$ The Concise Oxford Dictionary. $9^{\text {th }}$ ed., 1995, "palimpsest."

${ }^{2}$ Sarah Dillon, The Palimpsest: Literature, Criticism, Theory. (London, UK:

Continuum Literary Studies, 2007), 15.
}

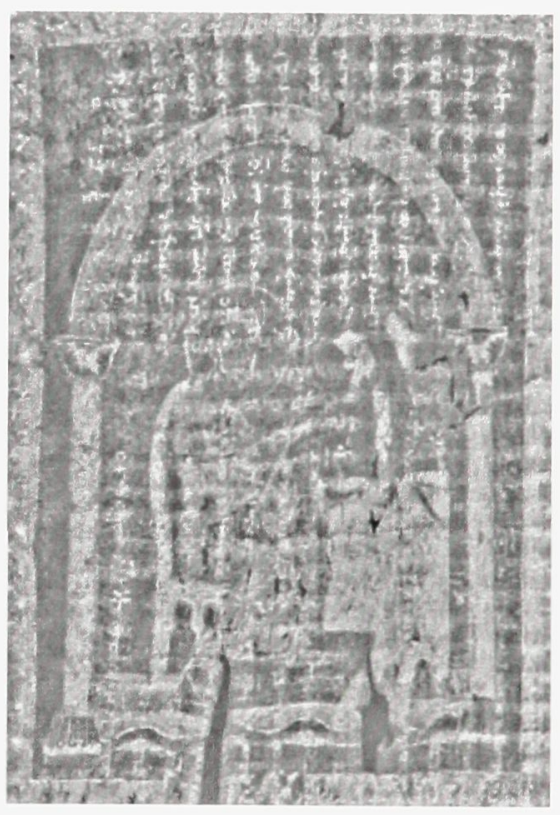

Figure 8: The Archimedes Palimpsest, Parchment 64, $12^{\text {th }}$ century. (The Archimedes Palimpsest is a medieval parchment manuscript, now consisting of 174 parchment folios.) 
text from the tenth century originally transcribed with text from one thousand years previous. (FIGURE 8)

As in the case of Archimedes' treatises, erased texts were referred to as underwriting or scriptio inferior while new texts were deemed to be superior. At this time concern existed for previous texts only with respect to their visibility after the process of erasure. Time however has proven the process of palimpsesting actually allowed the original layers of texts to be preserved in dialogue with their new counterparts. The erasure of original texts was often imperfect and the iron in the remaining ink oxidized and reappeared on the face of the palimpsest. ${ }^{3}$

Although new texts were not seen to be direct commentaries of / on the existing, these texts were still presumably written and read with respect to their scriptio inferior, especially after reappearing on the face of the palimpsest. Today references to the palimpsest have evolved to describe something of multiple layers or aspects existing beneath or beyond a surface or perception. ${ }^{4}$

Andreas Huyssen suggests it is the trope of the palimpsest and the "conviction that literary techniques of reading historically, intertextually, constructively, and deconstructively" have that one can begin to perceive "urban spaces as lived spaces that shape collective imaginaries" through their configurations and their unfolding in time. ${ }^{5}$ Architectural palimpsests are therefore buildings of multilayered stories, embedded with language and meaning.

\footnotetext{
${ }^{3}$ Sarah Dillon, 12 .

${ }^{4}$ Ibid.

${ }^{5}$ Andreas Huyssen, Present Pasts: Urban Palimpsests and the Politics of Memory (Stanford, CA: Stanford University Press, 2003), 7.
} 
Similar to the literary palimpsest, some layers are repressed while others are enhanced.

Rome has often been referred to as an architectural palimpsest. Building conversions in the ancient city allowed urban spaces to remain lived spaces as new layers of language and meaning were added to an existing history or character. ${ }^{6}$ Buildings were reused according to functional and economic value in their existing materials and construction as well as their cultural value as artefacts of collective memory.

The site of the Church of San Clemente in Rome, first graced with the house of St. Clement, the successor of St. Peter as the Bishop of Rome, during the Flavian period (second half of the first century,) shows how layers of language and meaning were added in the form of coverings over subsequent periods of time. ${ }^{7}$ (FIGURE $9 \& 10$ ) In the third century, a Mithraic temple was added to the existing courtyard. In the fourth century the existing foundations were built over with a hall and the walls of the hall were reused for the construction of a paleo-Christian church from 384 to 399 . It is speculated extensive renovations and restorations took place in the sixth century to consolidate elements within the church. At this time, the right aisle of the church was connected to a number of rooms to the north including a Baptistery. Finally, after a fire in 1084, the church was rebuilt in the twelfth century using the walls and supports of the ancient church as foundations; this would be the last layer added to the site. Since this time, the church has

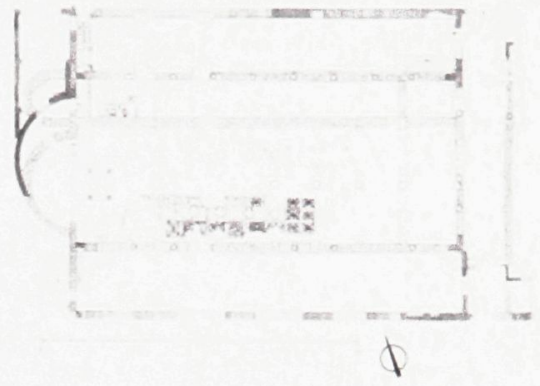

FIGURE 9: The Church of San Clemente, ground plan of the ancient church and its smaller early Medieval successor. Pavement of the sixth century (after Guidobaldi), Rome, Italy.

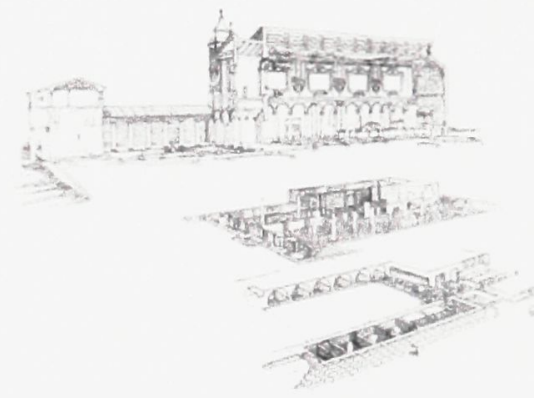

FIGURE 10: The site of the Church of San Clemente as built in layers beginning in the first century, Rome, Italy.

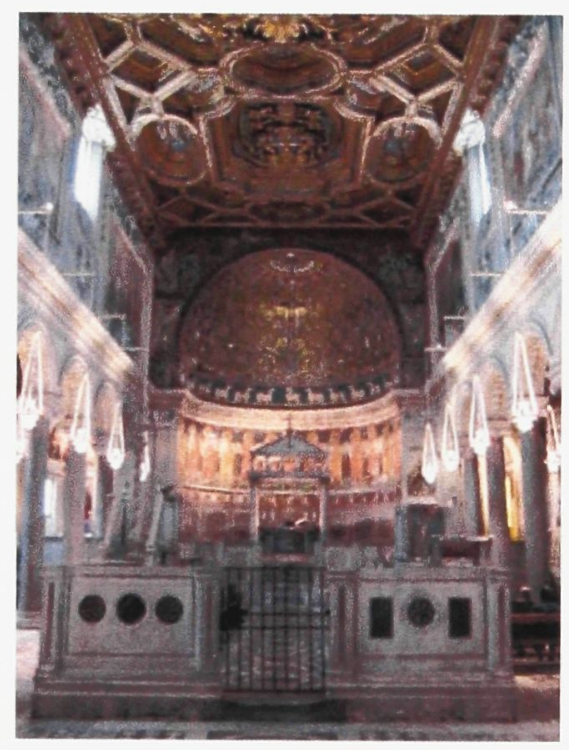

FIGURE 11: The interior of the Church of San Clemente as it appears today in Rome, Italy.

\footnotetext{
${ }^{6}$ Kenneth Powell, Architecture Reborn: Converting Old Buildings For New Uses. (New York, NY: Calmann \& King Ltd., 1999) , 9

${ }^{7}$ Hugo Brandenburg, Ancient Churches of Rome from the Fourth to the Seventh Century. Turnhout, (Belgium: Brepolis Publishers N.V., 2004), 142 - 152
} 
undergone several restorations and excavations during the nineteenth and twentieth centuries to uncover its layers of history - language and meaning. The church continues to weather and wear over time yet its use remains relatively consistent with that of the twelfth century and thus no longer warrants the addition of any new layers. (FIGURE 11)

Whereas the Romans once added layers to their existing buildings according to changing cultures and values with each subsequent period of time (ie. Ancient, Medieval, Renaissance and Baroque, Neoclassicism and Facism) this is no longer the case. Today the Roman palimpsest is largely being carefully preserved and excavated.

For those sites where a present form and function are no longer appropriate, the process of addition and subtraction is necessary to remain viable in the present as a living body. These palimpsests would necessarily continue to allow new texts to co-exist with old ones through the process of writing and erasure. In this way, the city operates as an entity of continual reuse and regeneration according to the needs of the city and the sustaining value the existing built forms of society hold.

Although new layers of language and meaning are continually added to the face of the palimpsest, often a sense of continuity results as opposed to a juxtaposition. In the palimpsest, thresholds between architectural elements, spaces and realms can become blurred and hard to define. Emphasis is placed on an overall aesthetic without acknowledging specific details and moments within the architectural project. (FIgURE 12) In Old Buildings as Palimpsest, conservation architect Rodolfo Machado professes he is weary of "the juxtaposition of different formal vocabularies in a remodelled

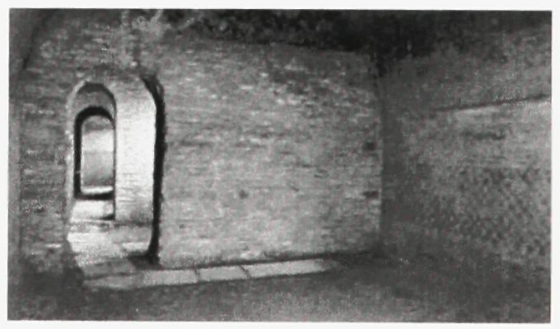

FIGURE 12: Blurring of transitions in the tufa block of San Clemente, first century, Rome, Italy. 
building [which] produces a natural "estrangement" that can enormously facilitate the criticism, the exposure, of architectural languages as cultural conventions." 8 However, Machado believes "this coexistence of vocabularies provides very rich grounds for the design of complex buildings that allow a multiplicity of levels of reading"9 and can highlight specific moments and details within the architectural project.

The building conversions and adaptations of Carlo Scarpa, in Italy from the mid twentieth century, begin to show how layers of the palimpsest can be placed in a dynamic dialogue. The Museo di Castelvecchio in Verona, Italy as renovated and reinstalled by Scarpa from 1958 to 1973, narrates the history of the site and continues to interact with the ethos of the present day. ${ }^{10}$ In this way, Scarpa's insertions provide new language to read and meaning to contemplate while grounded at the site of the original text. New text is applied at the connection points between spaces and realms as both commentary and conversation.

A look at how Scarpa intervenes at the Cangrande Space - a space of transitions and meeting points on the eastern side of the Commune wall in the sixth bay of the Napoleonic barracks of the Museo - reveals this dialogue. (FIGURE 13)

As an archaeologist would approach the site, Scarpa first carefully examines the existing layers to clarify the contents of each and to identify points of transition, adaptation and change. At this point, Scarpa decides which layers need to be

\footnotetext{
${ }^{8}$ Rodolfo Machado, "Old Buildings as Palimpsest." Progressive Architecture. Nov. 1976.

${ }^{9}$ Ibid.

${ }^{10}$ Carlo Scarpa renovated and re-installed the Museo di Castelvecchio first from 1958 to 1964 and subsequently from 1967 to 1973.
}

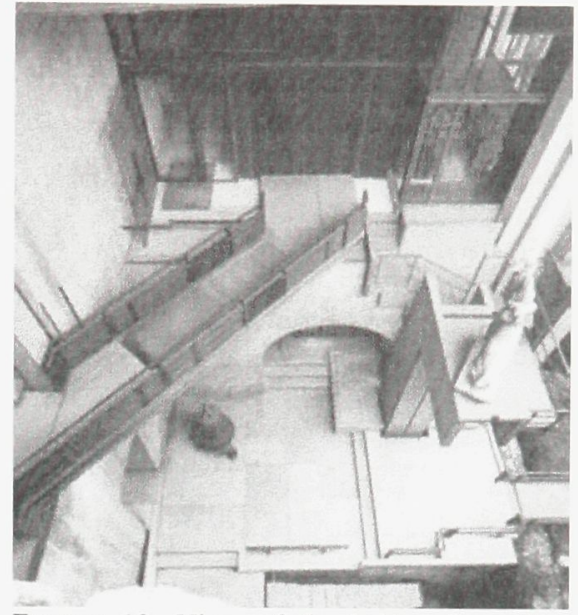

FIGURE 13: View of the bridge from the Commune wall to the south, Carlo Scarpa, Museo di Castelvecchio, Verona, Italy.

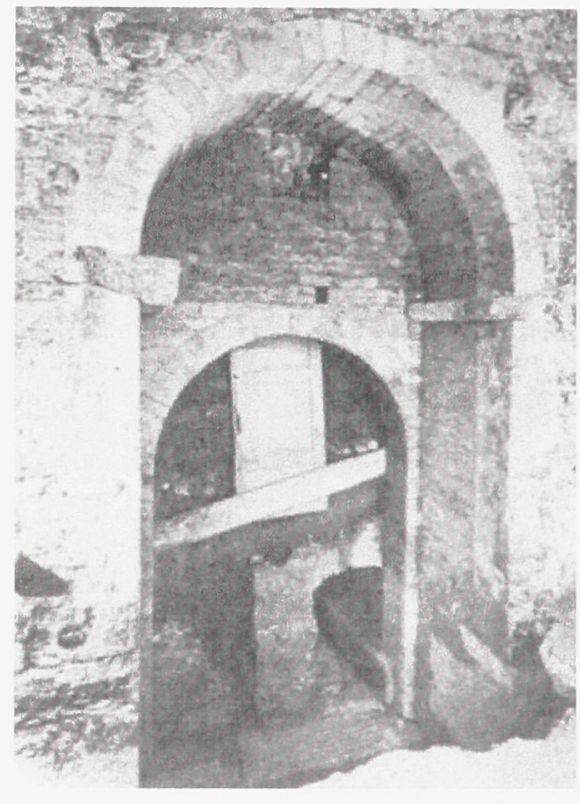

Figure 14: The Porta del Morbio during excavations, Museo di Castelvecchio, Verona, Italy 
kept and which layers can be demolished to "disentangle one epoch's construction from another so that the building itself becomes a giant exhibit revealing its growth and change in nature." 11 (FIGURE 14)

After this process of erasure, Scarpa begins to propose a series of additions to enhance the experience of the space for new users. For Scarpa, the addition of the first floor staircases, the bridge connecting the Commune wall to the galleries, the Cangrande statue pedestal and viewing platform, and the new roof structure are not "details but fundamentals, the essence of the built form and the thread that connect us to the past."12 (FIGURE 15)

While looking up to glance at the Cangrande statue, visitors note the addition of a new roof to protect the statue from wind and rain in response to the demolition of the sixth bay gallery. The roof is composed of two giant ridge beams from the former juncture as well as steel I beams, trussed rafters and copper plates. ${ }^{13}$ The steel I beams and trusses take the load of the roof and act as mediators between the Roman tile roof of the Napoleonic barracks, the eastern side of the Commune wall and the Torre del Mastio. By angling the I beam across the space, Scarpa deliberately defines a dominant geometry to acknowledge the inequalities in the severing of the two walls and to recognize the roof as a later addition to the space. The beam also supports the expression of actively being pushed back from the wall which is also

\footnotetext{
${ }^{11}$ Richard Murphy, Carlo Scarpa and Castelvecchio. (London, England: Butterworth Architecture, 1990), 4 .

${ }^{12}$ Jean-Francois Bedard, Mildred Friedman, Alba Di Lieto, Nicholas Olsberg, Sergio Polano, and George Ranalli. Carlo Scarpa Architect: Intervening with History. (Canadian Centre for Architecture and The Monacelli Press, 1999), 70.

${ }^{13}$ Richard Murphy, 94.
}

FIGURE 15: An early sketch of the Cangrande space at first-floor level, Carlo Scarpa, Museo di Castelvecchio, Verona, Italy.

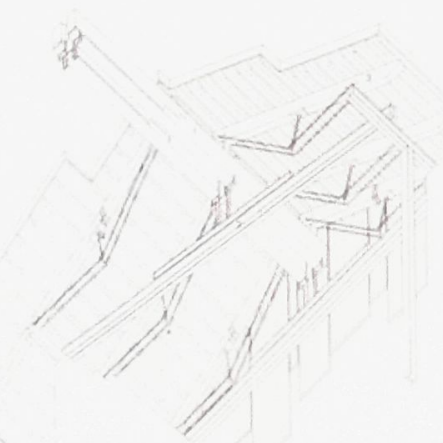

FIGURE 16: Axonometric of the Cangrande roof soffit from the southwest, Carlo Scarpa, Museo di Castelvecchio, Verona, Italy.

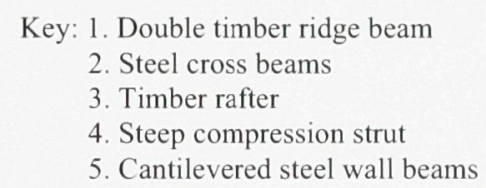


emphasized in the bunching of the trussed rafters. ${ }^{14}$ Finally, the face of the roof is made of horizontally aligned copper plates to contrast the vertically aligned Roman tiles of the barracks. $^{15}$ (FIGURE 16)

With every "detail," Scarpa takes the initiative to sensitively position the past and present in dialogue with each other to reveal the particularity of a place through a new use. Here the palimpsest provides both continuity and juxtaposition in the way of its spaces, tectonics and materials and reveals the joint as the moment of consciousness and of inspiration.

\section{The Margins of Berlin}

... there is latent strength in the margins. The first strength is that it is only from the margins that one can clearly view the center, and thus unravel all its closures, corruptions, and limits. - Jeremy Till and Sarah Wigglesworth

Within the confines of the printed page, margins are typically perceived to be blank and empty spaces, buffer zones between the central text and the page edge. Similarly, side margins are often referenced as gutters, deflecting text away from the bound edges of books. Spatially, margins are sites for outsiders and extras that either do not fit in with or have been displaced from a center. Kenny Cupers and Markus Miessen would go as far as to suggest these extra, leftover spaces often "constitute a marginal position, the ultimately transitory attitude that connotes powerlessness, or a refusal to intervene in the world." 16

\footnotetext{
${ }^{14}$ Ibid.

${ }^{15}$ Ibid.

${ }^{16}$ Kenny Cupers and Markus Miessen, Spaces of Uncertainty. (Wuppertal McColler und Busmann, 2002), 60 .
} 
By analogy, architecture of the margins can be described as buildings and programs on the extremities of a city or town. Using a delineation which is not only spatial but social, architecture of the margins can reference spatially centered buildings, in downtowns and urban centers, socially outside of a common, controlled, accepted center. ${ }^{17}$ In Spaces of Uncertainty, Cupers and Miessen explain how

visual research on cities [such as Berlin, Brussels and London] shows that the urban margin does not only exist in its very physical urban condition, in spaces outside the traditional understanding of public space, but in a number of phenomena that emerge in the actual social fabric of our everyday environment, outside the hierarchical organisation ... ${ }^{18}$

Buildings that have been abandoned or left to temporary uses remain within the margins of city life as sites 'in-transition.'

As a result of the second world war and the Reunification of Germany in 1990, marginal sites commonly exist throughout Berlin. After living and working in the city for an extended period of time, Cupers and Miessen become acquainted with these sites, noting perceptions and experiences. Their writing emphasizes how the traumatic effects of economic and social change have left buildings and people dislocated and disconnected, especially in the former East Germany. (FIGURE 17 \& 18) Without a central market / meeting place, Berlin is a hard city within which to navigate and to find ones way. Cupers and Miessen insist the city of "Berlin is clumsily unfinished. Its appearances do not reveal its different meanings."19

\footnotetext{
17 Jeremy Till and Sarah Wigglesworth, "Strong Margins." Architectural Regionalism: Collected Writings on Place, Identity, Modernity, and Tradition. (New York, NY: Princeton Architectural Press, 2007), 430.

${ }^{18}$ Kenny Cupers and Markus Miessen, 60

${ }^{19}$ Ibid, 58
}

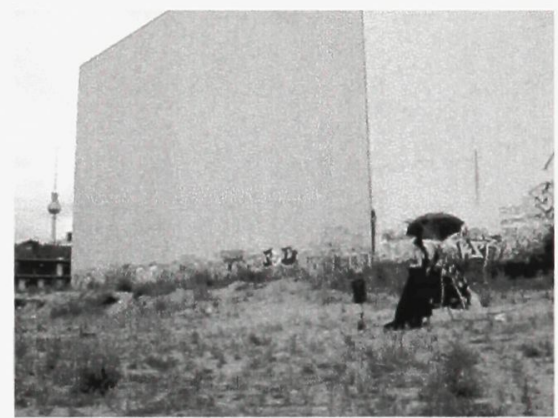

FIGURE 17: Berlin, Germany from Spaces of Uncertainty.

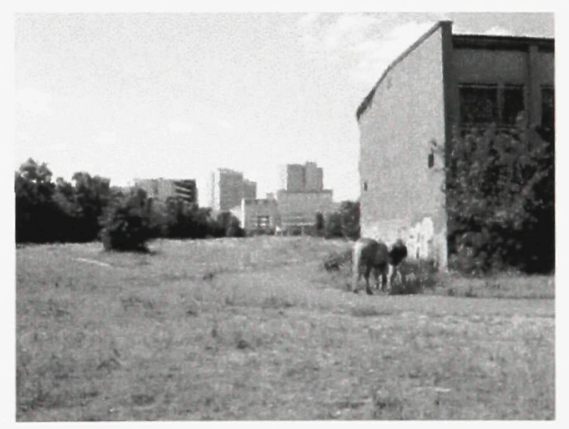

FIGURE 18: Berlin, Germany from Spaces of Uncertainty. 
Initially evoking profound reactions, at the inception of being placed in the margins, if not remedied properly these sites 'intransition' slowly pull away from any attachment to their history and former use. Effectively here, the present ethos is on trial and being tested. Sites wait for change, for reuse, for rehabilitation with no perceived currently viable attributes.

Yet, without the margins, how is the center to be defined? For the printed page, typographic gutters direct text away from the edge and, as margins, define the layout of the text. While architecture of the margins is perceived to be as empty as those typographic gutters and is often "pushed off into a corner, treated with disdain, or patronized with interest, „20 these sites also provide opportunities for real growth and creativity by first delineating and then commenting on the center, "as catalysts of experimentation." 21

In literature, marginalia describes the application of notes and editorial comments in the margins of books. While marginalia have been written over the years to conserve and to reuse materials, most often these notes additionally attempt to connect theories and facts between the writer and the reader through time and space. As the earliest known form of marginalia, the scholia of classical manuscripts were notes that introduced "information from outside the work that some scholar ... judged relevant to it - a grammatical or textual point, an elucidation, a new illustration, a historical reference, a contradicting authority." ${ }^{22}$ Scholia were printed in the margins and often completely surrounded the central text. An exemplary form of marginalia is found in the 1521 Latin

\footnotetext{
${ }^{20}$ Jeremy Till and Sarah Wigglesworth, 430.

${ }^{21}$ Kenny Cupers and Markus Miessen, 58.

${ }^{22}$ Scholia refers to a comment or lecture in Greek. H.J. Jackson, Marginalia: Readers Writing in Books. (New Haven, CT: Yale University Press, 2001), 45
}

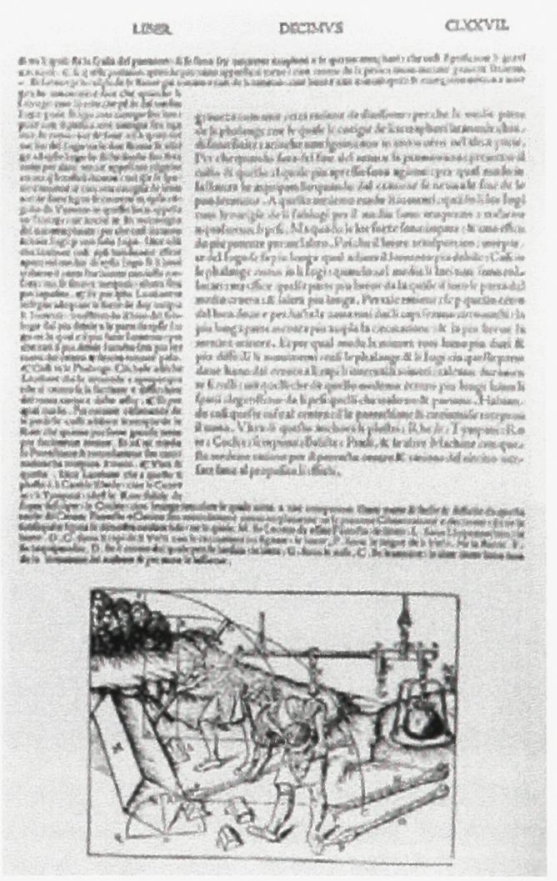

Figure 19: Cesare Cesariano's edition of Vitruvius' Ten Books on Architecture, 1521 
translation of Vitruvius' De Architectura by Cesare Cesariano. (Figure 19) A pupil of Bramante, Cesariano provided his own commentaries and illustrations based on his own observations and experiences working for and with Bramante, in context with the text of Vitruvius.

The content of marginalia is largely based on the ethos of the reader applying notes and used to comment on as well as clarify the value of the existing text to the new writer. Marginalia thus give meaning and potentially power to margins - sites of possibility and experimentation.

The use of marginalia in architecture helps to reconnect marginal sites to the center insofar as to provide linkages between places, spaces and times. It is not suggested here that the "margins should move inwards to be accommodated by the center (because that leads to a homogenizing suppression), but rather that the center disperse to accept the multiple values and diverse cultures, that the margins address." 23 In this way, the center realizes the profound relationship it has with its bound edge and appreciates it for the immense value and opportunities it provides.

Today, the work of architects in the city of Berlin has reclaimed the abandoned and marginal in a way that respects the temporal qualities of the margins. Buildings are reused by challenging their former functionality; "functions become activities, practices and opportunities." ${ }^{24}$ An exemplary project of the margins since the Reunification of Germany, the site of Arena Berlin Treptow boasts the reuse of a Berlin Transport Authority bus station and garage, originally

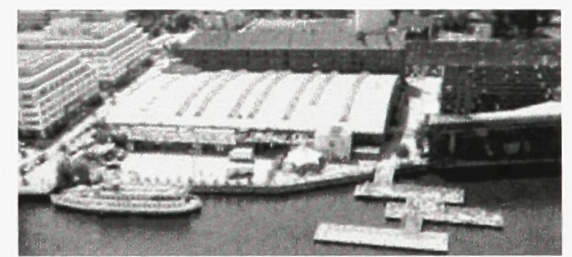

FIGURE 20: Aerial View showing the Halle, Glashaus, MS Hoppetosse and Swimming Barge with decks, Arena Berlin Treptow, Berlin, Germany.

\footnotetext{
${ }^{23}$ Jeremy Till and Sarah Wigglesworth, 430.

${ }^{24}$ Kenny Cupers and Markus Miessen, 122.
} 
constructed in 1927, as a concert and event hall; the reuse of the MS Hoppetosse, Anhalt service station and Freishwimmer Free Float boat rental and repair workshop, all originally constructed in the early twentieth century, as restaurants and bars; the reuse of the Glashaus event hall from the early twentieth century as a theatre and club; and the reuse of a barge as a swimming pool in the river Spree is connected to the site through the construction of decks. (Figure 20, $21 \& 22$ ) This site, once abandoned, is now home to a variety of programs and activities which challenge society to question the norm and open up to new opportunities and possibilities.

Based in Berlin, the architecture firm Urban Catalyst believes it is this reclamation that helps to "promote[] the return of financially weaker sections of society to a more active role within processes of urban change, which would lead to the inclusion of a more varied spectrum of interests, individuals, and spaces." 25 In this way, sites and spaces are constantly reused and re-imagined to remain viable as well as to push spatial and social boundaries.

\section{'In-Transition' In NORTH AMERICA}

Dull, inert cities, it is true, do contain the seeds of their own destruction and little else. But lively, diverse, intense cities contain the seeds of their own regeneration, with energy enough to carry over for problems and needs outside themselves. - Jane Jacobs

The cities of Rome and Berlin have been highlighted for their exemplary reuse of buildings in the form of palimpsests and marginalia. North American cities and towns however remain in a transition phase where the conversion of buildings, especially those of modest historical and

\footnotetext{
${ }^{25}$ Urban Catalyst, "Patterns of the Unplanned." Loose Space: Possibility and Diversity in Urban Life. (Abingdon, Oxon,: Routledge, 2007), 287.
}

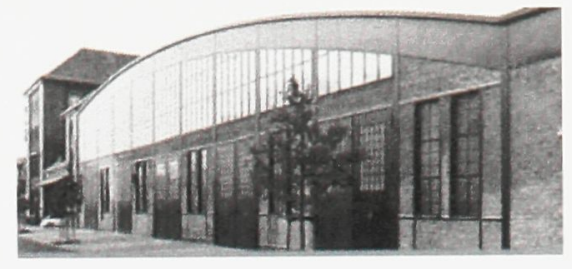

FIGURE 21: Halle Exterior, Arena Berlin Treptow, Berlin, Germany.

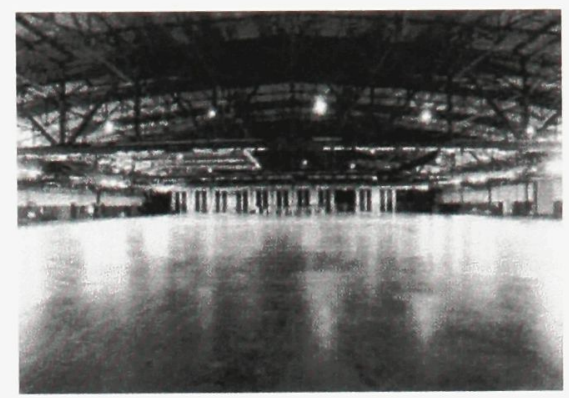

Figure 22: Arena Berlin Treptow Hall, Berlin, Germany. 
architectural value, is only now becoming more acceptable and commonplace as it was before the first world war. Until the beginning of the twentieth century, the functional and economic aspects of building reuse were its prime motivators in North America. At this time, new construction was perceived to cost more time, materials and funds than the reuse and adaptation of any existing structure. ${ }^{26}$

After the first world war however, architects began to imagine what the utopian city of tomorrow could and should be in order to counter the perceived ills of existing downtowns and urban centers in Europe as well as North America. (FIgURE 23 \& 24) In 1923, Le Corbusier presented his architectural treatise, Towards a New Architecture, as a reaction to the present form of society he suggested was becoming demoralized through the faults of existing buildings. Claiming "we are to be pitied for living in unworthy houses, since they ruin our health and our morale," Le Corbusier would sooner abandon the past for the immense potentiality of the next new generation and its machines. ${ }^{27}$ Similarly, Le Corbusier's Radiant City proposal, made an effort to forget the past and move forward to an architecture representative of this new modern age. As described in 1933, the Radiant City would be "the city of light that will dispel the miasmas of anxiety now darkening our lives, that will succeed the twilight of despair we live in at present, ...,28

Although one can appreciate the concerns Le Corbusier had for the existing cities of Europe, as well as his ambitions to

\footnotetext{
${ }^{26}$ Kenneth Powell, 9.

${ }^{27}$ Le Corbusier, Towards a New Architecture. (London, England: The Architectural Press, 1923), 18.

${ }^{28}$ Le Corbusier, The Radiant City. (New York, NY: The Orion Press, 1933), 94.
}

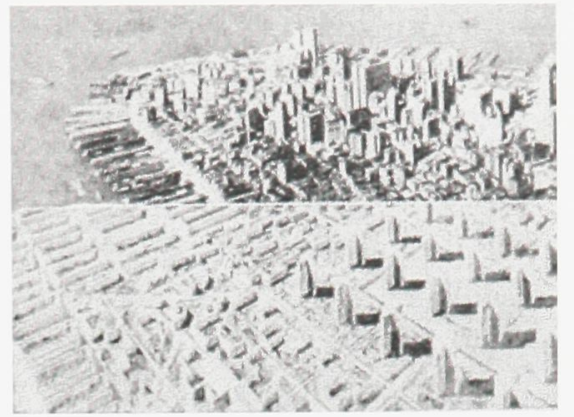

FIGURE 23: 1922: The two theses face to face: New York is not a city of the machineage civilization. New York is countered by the Cartesian city, harmonious and lyrical.

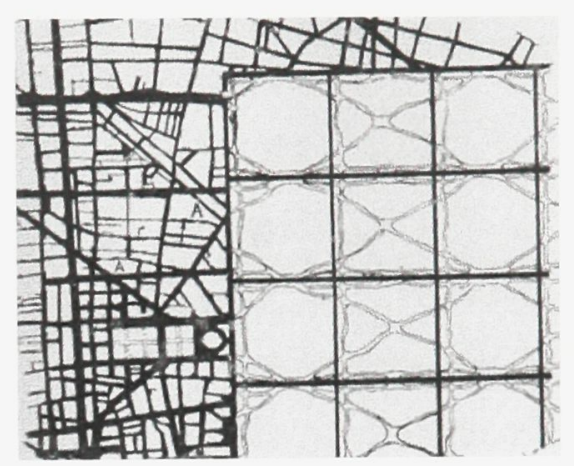

FIGURE 24: 1922: Here the two networks appear: In the era of the horse. In the era of the automobile.

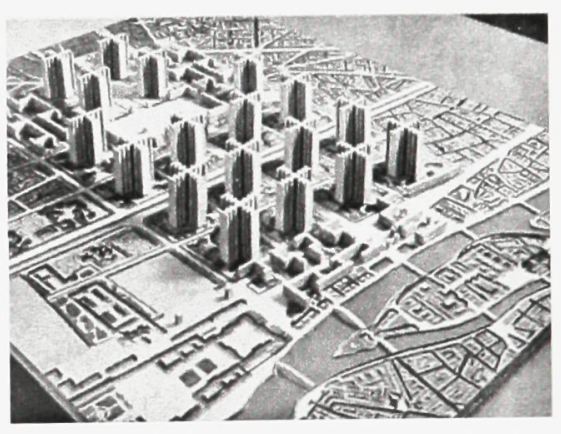

FIGURE 25: The Radiant City as proposed by Le Corbusier in 1933. 
"liberate the individual," 29 one must question the homogenizing form and activity of this new city through its definitive plan and standardization. (FIGURE 25) Le Corbusier claimed "all city neighbourhoods or cities ought to be organisms, ${ }^{, 30}$ yet in his plan there was no freedom to adapt and to grow against the controls of the new city. Freedom of expression would be lost along with any existing or present ethos. (FIGURE 26)

This redevelopment schema was further explored in North America through proposals such as Broadacre City in the 1958 publication of The Living City by Frank Lloyd Wright. (FIGURE 27) Wright believed the city of the nineteenth century had become a "fibrous tumor" no longer able to cultivate “organic" growth, only disease. ${ }^{31}$ Hence, Broadacre City proposed a decentralized plan which Wright explained would "spread wide, grow strong, the citizen free."32 Although Wright's ambitions were sincere, and focused on the individual as well as the collective community, this schema only proposed an alternative to the existing city. Wright claimed "organic architecture cultivates "the space within" as a reality instead of the roof and walls: it is building from inside out, instead of from outside in," 33 yet his proposal did not attempt to work within the confines of the existing city, to improve its growth and future development.

Although never fully realized, the proposals of Le Corbusier and Wright encouraged a period of urban renewal in North America during the immediate postwar period of the $1950 \mathrm{~s}$

\footnotetext{
${ }^{29}$ Ibid.

${ }^{30}$ Ibid, 147

${ }^{31}$ Frank Lloyd Wright, The Living City. (New York, NY: Horizon Press, 1958), 31.

${ }^{32}$ Ibid, 87.

${ }^{33}$ Ibid, 91 .
}

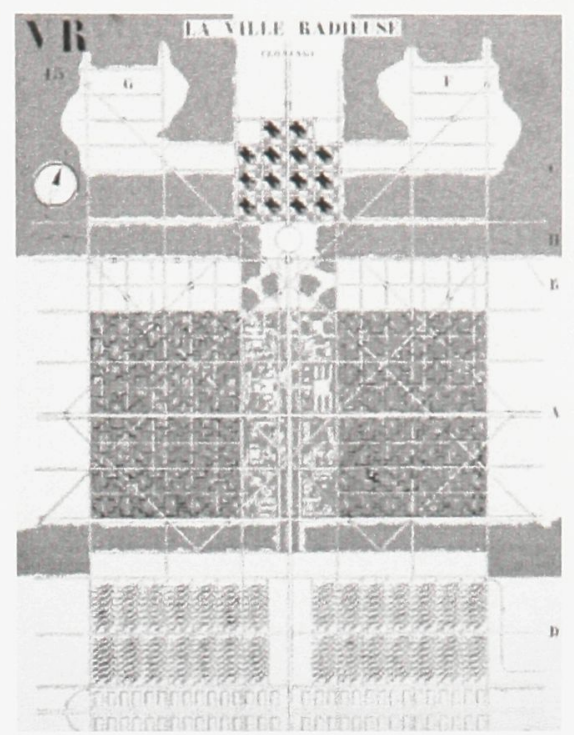

FIGURE 26: The Radiant City in plan as proposed by Le Corbusier in 1933.

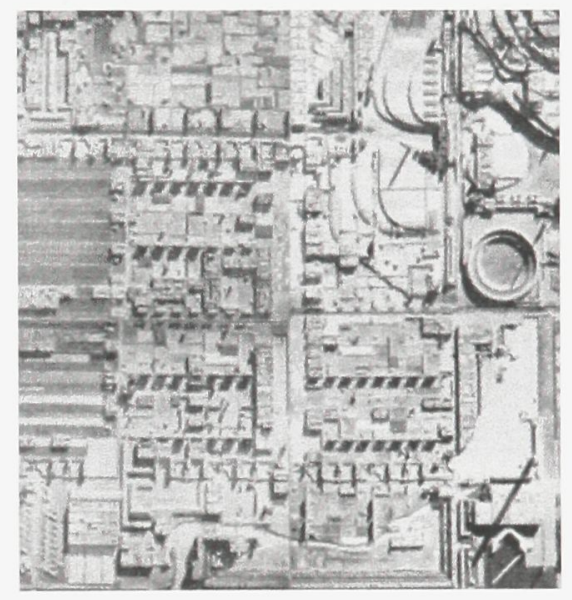

FIGURE 27: Broadacre City as proposed by Frank Lloyd Wright in 1958 . 
and 60s. During this time, cities were developed and redeveloped, often disregarding their existing scriptio inferior. Consequently, a mid $20^{\text {th }}$ Century North American mindset was generated, deeming the old and existing to be valueless, regardless of any embedded language and meaning be it through history, techne or functionality. Only the new was seen to be full of potential.

In some ways, this mantra became an undisputed truth. Jane Jacobs, in the introduction to The Death and Life of Great North American Cities, makes this discovery after walking the streets of the North End in Boston, Massachusetts. (FIgurE 28) Once considered to be physically deteriorating, badly overcrowded and inhabited by the desperately poor, Jacobs is amazed by the changes she sees in a 1959 visit. (FIGURE 29)

Dozens and dozens of buildings had been rehabilitated. Instead of mattresses against the windows there were Venetian blinds and glimpses of fresh paint. Many of the small, converted houses now had only one or two families in the tenements (as I learned later, visiting inside) had uncrowded themselves by throwing two older apartments together, and had equipped these with bathrooms, new kitchens and the like. I looked down a narrow alley, thinking to find at least here the old, squalid North End, but no: more neatly repointed brickwork, new blinds, and a burst of music as a door opened. Indeed this was the only city district I had ever seen - or have seen to this day - in which the sides of buildings around parking lots had not been left raw and amputated but repaired and painted as neatly as if they were intended to be seen. Mingled all among the buildings for living were an incredible number of splendid food stores, as well as such enterprises as upholstery making, metal working, carpentry, food processing. The streets were alive with children playing, people shopping, people strolling, people talking. Had it not been a cold January day, there would surely have been people sitting. ${ }^{34}$

Here Jacobs describes the ethos of the North End as energetic and full of diversity. Jacobs wonders how this district was

\footnotetext{
${ }^{34}$ Jane Jacobs, The Death and Life of Great American Cities. (New York, NY: Random House Inc., 1961), 9.
}

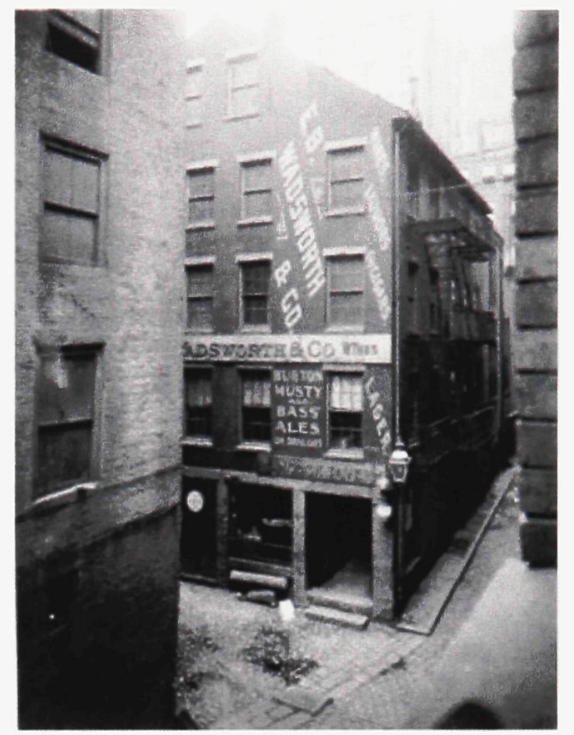

FIGURE 28: The North End, Boston, MA pre 1959

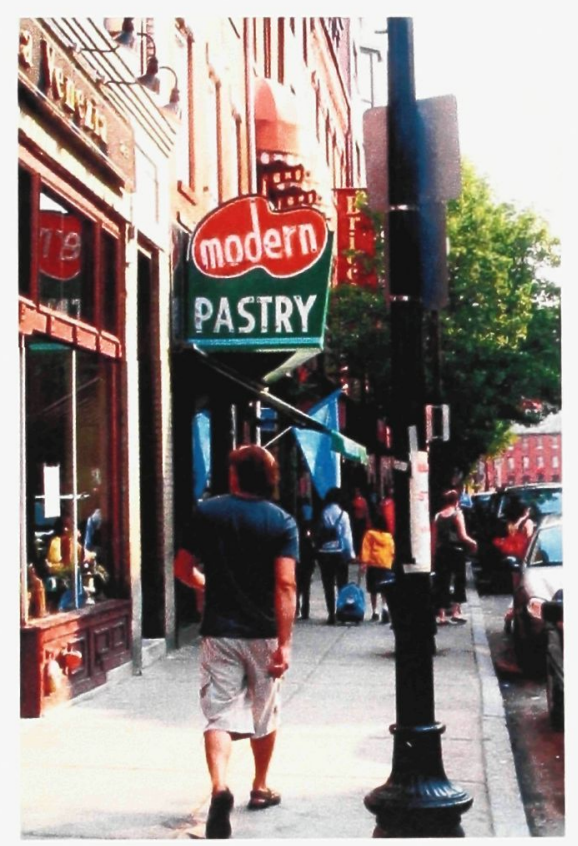

Figure 29: The North End, Boston, MA post 1959 
able to reinvent itself through its existing resources and calls a Boston urban planner she knows to find out the specific details. Although the urban planner is aware of the changes the area has ensued and enjoys "walk[ing] around the streets and feel[ing] that wonderful, cheerful street life," he is convinced the area needs to be rebuilt, no questions asked. ${ }^{35}$

Although effort has been made to conserve existing resources by select individuals, this is still not a common ethos for most. The mentality of the Boston urban planner still exists, as a large percentage of North Americans now live and work in cities more similar to those once proposed by Le Corbusier and Wright. Today, the automobile has removed residents from the cores of cities and displaced them to suburbia. As a result, the inner cores of existing cities and towns across Canada and the United States have become marginalized, underused and abandoned over time. Feeble attempts have been made to maintain buildings of architectural and historical value while more modest built heritage has been left to its own devices. It has not been realized that an 'ethos of sustenance' - an ethos that makes a genuine dwelling possible - relies on the past as well as the future.

Instead of running away from the leftovers of a previous time, it is possible to reuse more modest sites to cultivate a sense of both continuity and juxtaposition, constancy and change $e^{36}$

\footnotetext{
${ }^{35}$ Ibid, 10.

${ }^{36}$ Constancy and Change is the title of the publication from the inaugural CASA (Center for the Advancement of Studies in Architecture) symposium in 1991. In the words of the editors Malcolm Quantrill and Bruce Webb, to focus on constancy and change, it is necessary for us to understand our own dwelling in a particular time and place, and also to make connections with other times and places, yesterday and tomorrow. This involves traveling, in the mind, between our world and those other worlds. It also involves a sense of being in those other times and places, of developing an idea of what dwelling then and there was like, or will be. To do this we must make constructs; we have to reconstruct within ourselves those other frameworks of experience. Constancy and Change in Architecture. (College Station: Texas A\&M University Press, 1991).
} 
through architectural interventions specific to a place and time(s). 


\section{LOCATING AN \\ 'ETHOS OF SUSTENANCE'}

Ethos, we might say, appears in that socially created space, in the 'between,' the point of intersection between speaker or writer and listener or reader. - Karen Burke LeFevre

In Ethos as Location, Nedra Reynolds is convinced ethos is based on location, as it references the particularity of space, place and time. Within her writing, Reynolds proposes the feminist literary discourse of authors such as bell hooks, is authoritative based on how ethos is attributed to a particular location. For Reynolds "ethos is not something "embodied" by the classical orator with his audience, nor is it crafted in solitude by the modernist artist in his garret. Ethos ... shifts and changes over time, across texts, and around competing spaces." When writers reflect upon their ethos, effectively the source for their very being, they produce a language of their very own which is deeply embedded with meaning.

To locate ethos in literature, Reynolds claims, "requires attention to the mediation or negotiation that goes on in the spaces between writers and their locations." ${ }^{2}$ Ethos, thus, occupies the intersections between spaces, places and times and relies on specific connections which lend to its identification.

As writers change location, their ethos experiences a time of transitioning where the particularity of the new bears influence on the existing. In this way, the existing ethos is challenged, challenged to remain unchanged and challenged to change according to new surroundings. The degree to

\footnotetext{
1 Nedra Reynolds, "Ethos as Location: New Sites for Understanding Discursive Authority." Rhetoric Review, Vol. 11. No. 2 Spring, 1993, 326.

${ }^{2}$ Ibid, 333
} 
which this change ensues is ultimately dependent upon the grounds of the existing ethos.

The same can be said for sites 'in-transition,' where a catalyst of change challenges the current ethos of a locale. In building conversions, architectural interventions offer continuity and juxtaposition as palimpsests and marginalia and challenge an existing ethos through the new language and meaning they offer. Each intervention hence affords uniqueness in form, aesthetics and function, responding to the particularity of the existing building and surroundings. Whether or not any existing ethos is lost through a new intervention is based on how that character is interpreted and valued. One could argue however that any existing ethos is valuable, at least to know, as its identification helps to clarify and define the essence of a community, of an individual. This urge to know and understand the particularity of place locates an 'ethos of sustenance' which helps to cultivate the mind as well as the body through dwelling. 


\section{FOR OUR LADY SCHOOL}

The following text narrates my search for the lost ethos in Canada - Ontario - Lowertown West - 287 Cumberland Street - Our Lady School. A site 'in-transition,' the ethos of Lowertown West, surrounding Our Lady remains in a challenged, some would say, compromised position.

Cities and their sites are places for people. Their stories give life to the city. Through their voices we can learn more about Lowertown West and further question the current state of an area seemingly destined to lose part of its history and with it the value, meaning and language that once gave it a strong voice.

In the storia presented here, names of characters have been edited to conceal identities, however the facts and opinions presented to their reference remain true testaments of their ethos. The storia is read as a web of theories, facts and interpretations that expose the essence of a place yesterday, today and tomorrow. Yesterday is referenced as per the available documentation of history, whereas today and tomorrow are based on my own interpretations from personal conversations and connections with the Lowertown West community.

I of course bring my own knowledge and background to the project and am influenced by what I believe to be right and true based on my own experience. It is understood that my approach to this project is unique based on the fact that it is done by me and is conducted through my ethos. I bring with 
me my past, my present, my expectant future - all which form the basis that leads me to learn more about this site. Knowing me is to know the reasoning for my approach and the outcome that results.

As an outsider to Lowertown West, I am challenged to understand existing connections within the layers of history that have been written and to suggest new layers that might be added to reveal an 'ethos of sustenance.' To this effect, the theoretical text acts as a base for the narrative of the site that brings life and meaning to the body. The narrative is a sequence of events described through my experience with the site. It is not a simple chronology but a web of theories, facts and moments that I have discovered and experienced over the past year. From my research, I have come to understand the value, meaning and relevance of intangible collective memories, tangible structures and material use, present and potential use by artists and residents and the process by which architectural interventions will help to cultivate the site of Our Lady School and its surroundings.

The storia that follows, hence, is like no other. Although it can be linked to other sites 'in-transition,' it has its very own unique voice, dependant on its particular history and future. 


\section{COllective Memory}

The present contains nothing more than the past, and what is found in the effect was already in the cause. - Henri Bergson

For Henri Bergson, memory is formed at "the point of contact between consciousness and matter;" awake in the present, facts and thoughts are documented with reference to the corporeality of the senses. ${ }^{1}$ Memory is collective when it is formed by a group of individuals or is held in the minds of a collection of people. Collective memories not only recognize those shared experiences of a nation, state, city, community or group but act as the collection of temporal (time) reflections of - connections to - a physical and metaphysical past. $^{2}$

Collective memories reveal the origins and cultures of a specific place and people, and can expose embodied meaning, and often latent value within the built environment. The history of a site can be uncovered through careful examination of its physical artefacts, the architecture of the site, which can recall stories from times past. Site stories can be revealed through spaces, tectonics and weathering which unveil the temporality of architecture and the processes of change it is continually exposed to. Over time, the spaces of a building may be altered as its uses change; the tectonics of a new addition or renovation may vary from those of the original construction to address a specific time in history; the weathering of a building, exterior and interior, may display

\footnotetext{
${ }^{1}$ Suzanne Guerlac, Thinking in Time: An Introduction to Henri Bergson (Ithaca, NY: Cornell University Press, 2006), 5.

${ }^{2}$ Maurice Halbwachs would suggest collective memories are essentially social and are recalled by referencing specific places, times and ideas within patterns of thought that can be linked to specific social groups. He says, our memories remain collective, however, and are recalled to us through others even though only we were participants in the events or saw the things concerned. In reality, we are never alone. Other men need not be physically present, since we always carry with us and in us a number of distinct persons. The Collective Memory. 23.
} 
the marks of time and allude to the constant processes of evolution and change the site is part of.

For Adolf Loos, site stories, represent the age-value of architecture which regards aging as an "enhancement" and the idea that the various surface markings act as physical recordings of the history of a building and the human life associated with it. $^{3}$ Today however, weathering is largely perceived as a subtractive process that removes integrity and value from materials and objects. While architecture necessarily requires surface care according to its material use, this general up-keep often removes all signs of aging. In this way, architecture is distanced from its context (the particularity of its place) and acknowledged instead as an object in a landscape.

In On Weathering, David Leatherbarrow illustrates how the white walls of Le Corbusier, specifically at Villa Savoy, epitomize this mindset; "the white surface was thought to be the basis of objectivity" and of "truth;" the "eye of truth." As one would expect, the white walls of the Villa stain and wear over time yet are perfectly preserved shortly thereafter. (FIGURE 30 \& 31)

While the white walls of Villa Savoy may be "the eye of truth," according to specific design principles Le Corbusier notes, the walls outwardly deny any potential existing truth in relationship to a place and time. In this image, is it not possible to embrace change and the aging associated with it in light of specific design criteria?

\footnotetext{
${ }^{3}$ This understanding of age-value is shared by Alois Riegl in The Modern Cult of Monuments from 1903. Here Riegl suggests "age value refers to changes caused by weathering and use over time, including the patina of age, the lack of integrity, and the tendency to dissolve form and colour." Jukka Jokilehto. A History of Architectural Conservation. Woburn, MA: Butterworth-Heinemann: 1999, 216.

${ }^{4}$ David Leatherbarrow and Moshen Mostafavi, On Weathering. (Cambridge, MA: MIT Press, 1993), 84.
}

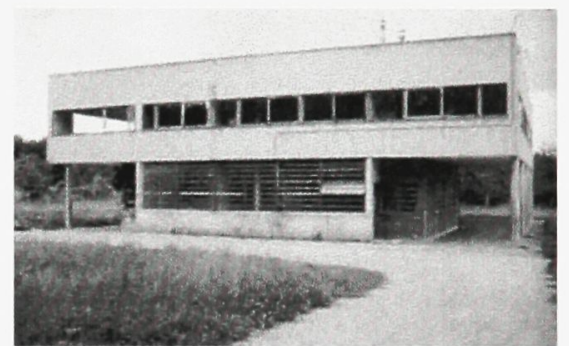

FIGURE 30: Villa Savoy before preservation, Poissy France, 1928-31.

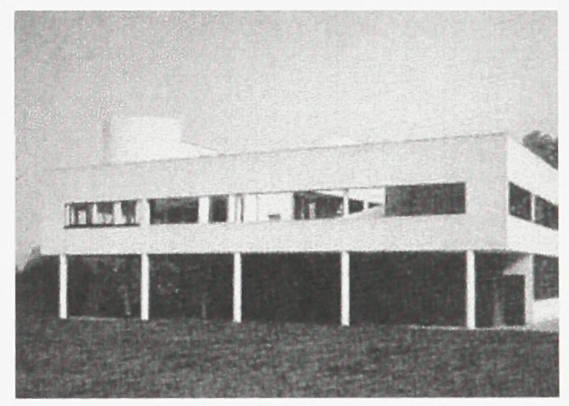

FIGURE 31: Villa Savoy after preservation, Poissy France, 1928-31. 
For Alois Riegl, historical value is apparent in the episteme, knowledge, of techne, the making and doing of architecture, once based on its context. ${ }^{5}$ Over time however, this regional distinctiveness has generally been lost as the existing built environment is often not valued for the episteme of techne it offers and new projects tend to bare a new global aesthetic. An international palette of materials was first made possible in the early twentieth century as the result of industrial and technological advancements including the ability to produce building materials en masse.

When the same materials and methods of construction are being used internationally, one must wonder if the particularity of a place is considered at all. Leatherbarrow insists,

architecture made up of a "kit of parts" changed the relationship between a building and its potential site, allowing assembly and construction to take place on any site, to a great degree independent of its local environment and climatic conditions - which paradoxically makes it siteless. ${ }^{6}$

If the historical and age value of sites were no longer present, sites could no longer be read as stories from the first conception of architecture to the present and the physical manifestations of a culture's built heritage would be lost. Few opportunities would exist to recall facts, events and impressions of the past through architecture. Without collective memories as stimulated by the built environment, says Andreas Huyssen, society suffers from cultural

\footnotetext{
${ }^{5}$ Alois Riegl recognizes that it is only around the beginning of the twentieth century have we come to recognize the necessary consequences of the theory of historical evolution, which declares that all artifacts of the past are irrecoverable and therefore in no way canonically binding. Alois Riegl, "The Modern Cult of Monuments: Its Character and Its Origin." In Oppositions Reader. (New York, NY: Princeton Architectural Press, 1998), 622.

${ }^{6}$ David Leatherbarrow and Moshen Mostafavi, 29.
} 
amnesia. $^{7}$ Here the physical link to interrelated memories among people, places and events is lost. Huyssen suggests it is the commodification and marketing of memory that has made society numb to the richness of history and thus causes disregard for a culture's built heritage. ${ }^{8}$

Too many Canadian cities, towns and communities sadly suffer from cultural amnesia. These cities, towns and communities have developed at their peripheries without attempting to reuse the existing building stock in downtowns and on main streets. As a result, over time many existing buildings have become underused and abandoned. According to the Heritage Canada Foundation, Canada has lost more than twenty percent of its pre-1920 heritage buildings to demolition over the past thirty years. ${ }^{9}$ As the number of buildings lost in recent history is distressing, the Foundation now places emphasis on the urgent action required to restore and reuse heritage buildings for their "value as a reminder of our origins and cultures." 10

The Washington Charter for the Conservation of Historic Towns and Urban Areas from 1987, created by ICOMOS (the International Council on Monuments and Sites) acknowledges the value of built heritage and encourages efforts to maintain it.

\footnotetext{
${ }^{7}$ Andreas Huyssen, Present Pasts: Urban Palimpsests and the Politics of Memory (Stanford: Stanford University Press, 2003), 21.

${ }^{8}$ Andreas Huyssen is currently the Villard Professor of German and Comparative Literature at Columbia University. Huyssen specifically analyses cultural amnesia in Berlin, Germany where nearly eighty percent of the city was lost during the second world war. In Present Pasts: Urban Palimpsest and the Politics of Memory, Huyssen explains the effects of this loss on the people of Berlin through both memory and forgetting.

${ }^{9}$ Heritage Canada Foundation, Federal Financial Tax Incentives for Heritage Places (SOC08.3.07) February 122008

$<$ http://www.heritagecanada.org/eng/services/advocacy.html> November 2008.

${ }^{10}$ Ibid.
} 
All urban communities, whether they have developed gradually over time or have been created deliberately, are an expression of the diversity of societies throughout history.

Beyond their role as historical documents, these areas embody the values of traditional urban cultures. Today many such areas are being threatened, physically degraded, damaged or even destroyed, by the impact of the urban development that follows industrialization in societies everywhere.

Faced with this dramatic situation, which often leads to irreversible cultural, social and even economic losses, [the charter] ... seeks to promote the harmony of both private and community life in these areas and to encourage the preservation of those cultural properties, however modest in scale, that constitute the memory of mankind. ${ }^{I I}$

Although the Washington Charter would have one believe concern extends for built heritage "however modest in scale," size and value, reality reveals a myopic focus which addresses only an elite portion of the existing building stock, that is (in Canada) designated properties deemed to be historically and / or architecturally significant by federal, provincial and municipal governing bodies. ${ }^{12}$ The Ontario Heritage Act, first enacted on March 15, 1975, designates individual buildings and Heritage Conservation Districts according to Part IV and Part V of the Act respectively. And where buildings are recognized and designated, effort is made in the way of preserving and protecting these sites.

\section{AUTHOR-ITY}

To award heritage conservation designation to a specific district of a municipality in the province of Ontario, a request must first be submitted to City Council to determine the boundary of the area to be studied in consultation with the Municipal Heritage Committee.

\footnotetext{
${ }^{11}$ ICOMOS. The Washington Charter. 1987

$<$ http://www.international.icomos.org/charters/towns_e.htm> November 2008.

$12.5 \%$ of the existing building stock in Canada is recognized and designated as having historic and / or architectural value.
} 
When the study area has been determined, a study team, comprised of heritage and restoration consultants, architects, architectural historians and archaeologists, is formulated to research the chosen area and provide recommendations for designation and future growth. If recommendation is given to proceed with the designation of the district, a Heritage Conservation District Plan is created with guidelines presented to City Council. City Council then creates a by-law to enforce Part $\mathrm{V}$ of the Ontario Heritage Act for that district and notifies the district property owners, Ontario Heritage Trust and public of the designation. (FIGURE 32)

While it is encouraging to note the involvement of communities in the designation of Heritage Conservation Districts within the province of Ontario, the process to designate a district is lengthy and often not appropriate for many sites. Hence, if only a select number of sites are in fact designated and recognized, how can further concern be cultivated for buildings of modest heritage value to encourage their reuse in the face of threatening abandonment - redevelopment?

It seems this remains a challenging task, especially when heritage review boards such as the Federal Heritage Building Review Office (FHBRO) seemingly commodifiy built heritage by classifying federally owned properties according to specific evaluation criteria. This criteria includes the history of the site (thematic, person / event, local development), the quality of architecture (aesthetic design, functional design, craftsmanship and materials, designer), and the environment where the building is sited (site, setting, landmark). FHBRO does not accord the same value to all evaluation criteria and thus within the three criteria also

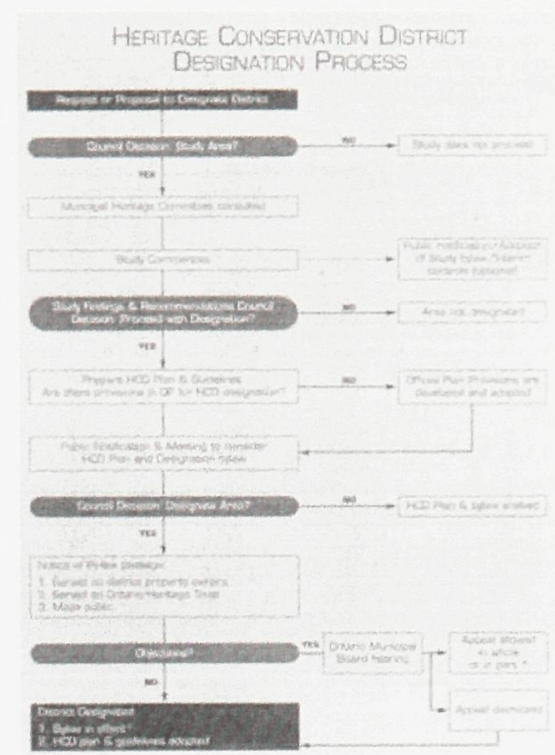

FIGURE 32: Designating a Heritage Conservation District in the Province of Ontario. 
accords constituent sub-criteria different values. Aesthetic design for example is worth more than functionality, craftsmanship and the repute of the architect. No separate or additional consideration is given to those buildings which could be classified if assumed weightings for each evaluation criteria were different. The number of classified buildings in Canada would significantly increase if allowances were made to uncover the actual source of value for each site in question. ${ }^{13}$ Instead, FHBRO imposes the same set of evaluation criteria and values on every building and holds authority over the physical manifestations of collective memory, with regards to federally owned property within Canada.

Instead of offering all emphasis, effort and subsequent funds to an elite portion of the existing building stock, a more proportionate distribution of attention could be realized and instituted. Although it may be appropriate to acknowledge variation in the historic and architectural value of built heritage, it is not appropriate to use such evaluation to exclude the overwhelming majority of existing buildings within Canada from being considered part of that heritage. Although modest in scale and perceived value, these sites remain significant to the heritage (inheritance and subsequent growth) of a city, town or community.

Values-based conservation decision-making systems can further be implemented and encouraged even where sites are not designated properties. Otherwise, the true heterogeneity of the existing building stock is not recognized and modest heritage is devalued and misunderstood. Underappreciated, underused and abandoned, modest heritage particular to its

\footnotetext{
${ }^{13}$ The objective of this thesis is not to propose every site be designated. Instead values-based approaches can be used to allow appropriate responses for each site being evaluated.
} 
place is often gradually replaced by buildings of homogeneous value. This replacement is often warranted by property owners for economic and newness value yet disregards historical, age and potential use value.

In the redevelopment and urban renewal schemes that ensue, developers and architects, author-itarians themselves, offer little regard for the present modest heritage of communities as a basis for investing in future possibilities and potentialities. In so doing, Christine Boyer believes "we have lost a moral public sphere in this sea of plural voices; [and that] the better argument wields no collective weight, actually enabling the public sphere to be dominated by private voices selling fictional styles of life and imaginary behaviours." 14 Present communities, which can hardly be pluralized (identified as one), are given a small voice in the design of an architectural intervention, if any voice at all, and only after the first iteration of a redevelopment scheme has ensued. At this point, the community has already become an outsider, holding little influence on those with legislative or financial power. The ethos of the site is hidden and eventually lost during the planning and design process.

Denis Hollier suggests there are benefits in searching for deeper meaning and value in objects [and architecture], rooted in history, instead of accepting their worth at face value.

\footnotetext{
${ }^{14}$ Christine Boyer is currently a Professor of Urbanism at Princeton University School of Architecture. Christine M. Boyer, The City of Collective Memory. (Cambridge, MA: The MIT Press, 1994), 4.
} 
Just as the psychoanalyst must give everything equal attention, just as the surrealist, in automatic writing, must let everything come through, so must the anthropological collector keep everything. He must never privilege an object because it is beautiful never exclude another because it seems insignificant, or repugnant, or formless. ${ }^{15}$

The cultural anthropologist considers how, why and where the physical manifestations of human nature have been conceived, have been used, have been modified, and have been discarded. Architecture can be viewed in a similar light by acknowledging how and why architectural spaces and tectonics are created, when and where they are in order to uncover their embodied meaning and often latent value. To this effect, benefits will be gained by consulting present and potential future communities prior to commencement of the design process for any renovation, rehabilitation or new construction. By addressing and consulting the community and those with vested interests in the site prior to and beyond the duration of design, deeper meaning will be brought to the forefront where the character of the site can be better recognized, maintained and enhanced.

\section{To Preserve and To Protect}

After sites have been designated by authorities, there is a tendency in many circumstances to negate age-value in favour of other values including intentional and historic (unintentional) value, as Alois Riegl suggests in The Modern Cult of Monuments: Its Character and Its Origin. Rooted in nineteenth century Romantic and Historicist theories first iterated by European nations, such commemorative value is sought through preservation efforts which were translated to

\footnotetext{
15 Denis Hollier is currently the Academic Director of the French Department in the Faculty of Arts and Science at New York University. With reference to architecture, Hollier has studied the writings of George Bataille who claimed "architecture is the expression of every society's very being." Denis Hollier and Liesl Ollman, "The Use-Value of the Impossible.” October. Vol. 60. Spring 1992, 15.
} 
North American initiatives well into the twentieth century. Through organizations such as APT (the Association of Preservation Technology), the historic preservation movement remains strong to this day within the United States as does the conservation movement within Canada.

Accordingly, restoration attempts to maintain the historical integrity of an architectural style or period and in so doing evokes a sense of permanence while preservation attempts to slow down aging processes to protect sites in their found state. By awarding, potentially superficial, permanence to sites, the temporality of architecture is negated along with its collective ethos of the past, present and future. ${ }^{16}$ While it is understandably necessary to protect select sites for educational purposes, restoration often commodifies the past by removing present and future context. This musealization, as Hollier would define it, has no bearing on the ethical function of architecture which necessitates present and future use in its temporality. ${ }^{17}$

For most built heritage it is appropriate to acknowledge the embodied traces of history that have been acquired over time, in the form of spaces, tectonics and weathering. In this way, sites are treated as palimpsests of continual change and adaptation according to use, reuse and new use. How multiple layers of physical and metaphysical substance can be added without blurring or severely altering stories, however, requires further explanation.

\footnotetext{
16 The term 'potentially superficial' as used to reference the permanence of architecture recognizes the impossibility to completely remove architecture from processes of change. It is only through continual maintenance of the physical object that preservation can be permanent.

${ }^{17}$ Denis Hollier and Liesl Ollman, "The Use-Value of the Impossible." 9.
} 


\section{NEGATION AND RECONCILIATION}

Although one may desire a perfect memory, one understands the impossibility of acquiring it. Without hyperthymesia, the mental capacity of the human brain does not allow every detail of every experience to be remembered. ${ }^{18}$ The beauty of memory lies in the fact that it is imperfect and fleeting and requires the careful documentation of people, places and events in order to be recalled. When Hollier describes the work of the cultural anthropologist he suggests, "everything must be said, yes, but on the condition that not everything can be said."19 In order to give meaning and significance to particular spaces, places and times, some memories must be emphasized while others are suppressed. Memory is thus selective and "indissolubly linked" to forgetting as Huyssen suggests

the act of remembering is always in and of the present, while its referent is of the past and thus absent. Inevitable, every act of memory carries with it a dimension of betrayal, forgetting, and absence. ${ }^{20}$

When built heritage is restored and preserved, ties to the present and future are largely negated to place all perceived value in the past.

When built heritage is underused, abandoned and demolished, it is often forgotten and all memories once recalled through points of contact with this matter are also lost.

\footnotetext{
18 Hyperthymesia or hyperthymestic syndrome is a condition where the affected individual has a superior autobiographical memory. The two defining characteristics of hyperthymesia are 1) the person spends an abnormally large amount of time thinking about his or her personal past, and 2) the person has an extraordinary capacity to recall specific events from their personal past.

${ }^{19}$ Denis Hollier and Liesl Ollman, "The Use-Value of the Impossible." 9.

${ }^{20}$ Andreas Huyssen, 3-4, 17.
} 
When new architecture rises on a razed site, all references to and groundings in history are negated with no source of reconciliation. A utopian vision for tomorrow supposedly takes the place of a subservient past, providing no acknowledgement of a prior existence. The result is a lack of cultural sustenance and gradual loss of collective memory.

Sensitive negation and reconciliation ties the past to the present and the present to the future. According to Raimund Abraham, "the process of design is only a secondary and subsequent act, whose purpose is to reconcile and harmonize the consequences of the initial intervention, collision, and negation." 21 It is this sensitive negation and reconciliation, within the scope of the architectural intervention, that allows the historical and /or architectural integrity of an existing structure to be maintained while implementing contemporary utility. By consulting all stakeholders of an architectural intervention whether renovation, rehabilitation, new construction, the architect, as the primary author-ity, is effectively responsible for framing and constructing an implied deeper meaning through use of both memory and forgetting.

Even with sites of tragic stories where forgetting presupposes remembrance, it is pertinent to reveal the integrity of the site; "one must expose the taboo and, in exposing it, expose oneself., 22 Naivety may be bliss but it is bliss achieved at a cost. Huyssen believes

\footnotetext{
${ }^{21}$ Raimund Abraham, "Negation and Reconciliation." Perspecta, 1982, 7.

${ }^{22}$ Denis Hollier and Liesl Ollman, "The Use-Value of the Impossible." 18.
} 
we need both past and future to articulate our political, social, and cultural dissatisfactions with the present state of the world. And while the hypertrophy of memory can lead to self-indulgence, melancholy fixations, and a problematic privileging of the traumatic dimension of life with no exit in sight, memory discourses are absolutely essential to imagine the future and to regain a strong temporal and spatial grounding of life.$^{23}$

Through a deeper understanding of the present in relationship with the past, a stable, coherent, sustaining foundation can be cast for subsequent generations. Prudence in architecture henceforth lies in an understanding of the physical manifestations of history albeit whether they are historically and /or architecturally significant. If the future is built on anything but the integrity of its past and present where will its footings lie and how will it be grounded?

\section{Cultural Sustenance: In MaIn Streets and Downtowns}

Main Street is the glory of Canada. If a community has no heart, it has no soul; and its heart should beat faster at the core. For here is the glory of the past, the symbol of stability, the structures that our fathers and their fathers erected, the visual reminder of another time that gives every small town a sense of continuity. - Pierre Berton

Main streets and downtowns hold the collective memory of cities, towns and communities yet are being threatened by the prospect of new development at their peripheries throughout North America. (FIgURE 33) Often these streets and downtowns have acted as the central meeting places for numerous groups of people over time. Why should these areas not continue to function in the present and continue to provide cultural sustenance that gives value, meaning and identity to the built environment? An 'ethos of sustenance' has been lost where

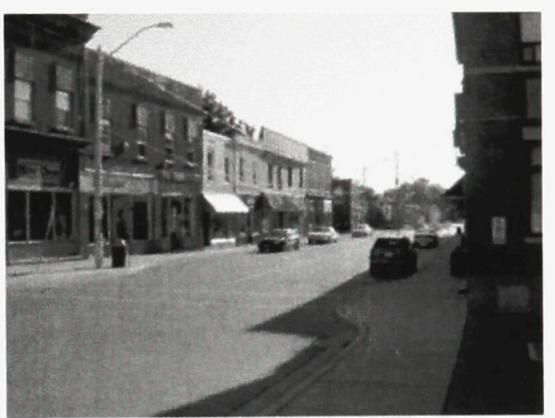

FIGURE 33: Main Street Waterford, Ontario, author's hometown in 2009.

\footnotetext{
${ }^{23}$ Andreas Huyssen, 6.
} 
culture, embodied in the built environment, is no longer seen as a valuable resource to sustain.

After the regional mall and suburban development encouraged the displacement of Canadian communities from their main streets and downtowns in the 1960s, the Heritage Canada Foundation fought to sustain this built heritage. In 1979, the Main Street Canada Program was established to shift focus back to downtowns recognizing their historical roles, value and potential future use. In this way, some of the country's more modest heritage was used as a tool for economic development. First initiated in Perth, Ontario, the Main Street Canada program extended its efforts to seventy communities during the ten years it existed extensively within Canada. (Figure 34 \& 35) Store front main street offices were established to create a presence within towns and communities, as the program sought input from all potential stakeholders. Although the program had immense positive impact on the conservation of physical and metaphysical attributes defining the original and evolving character of these cities and towns, financial support eventually shifted to other initiatives.

Nearly twenty years have passed since funding was largely halted for the Main Street Canada Program. In this time, many cities and towns aided by the program continue to prosper while others have once again declined, succumbing to changing socio-economic forces.

In March of 2009, the Heritage Canada Foundation prepared Main Street: Past and Present for Saskatchewan Tourism, Parks, Culture and Sport to aid in "options development for a Main Street-type approach to suit Saskatchewan's geography, population density, circumstances and goals, responding to

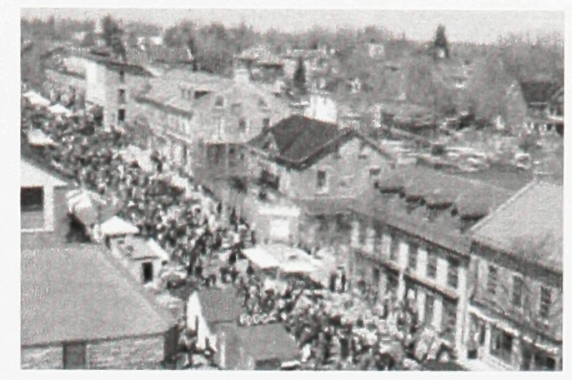

FIGURE 34: Perth, Ontario during Maplefest in April of 2002.

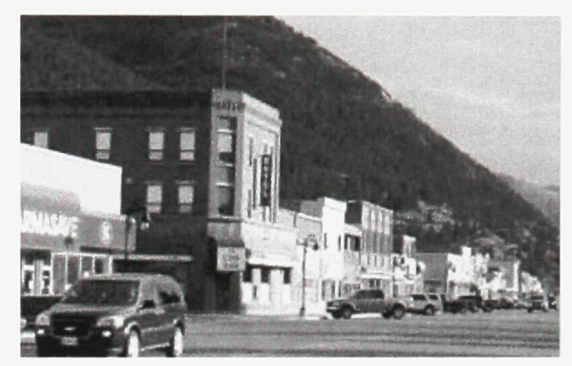

FIGURE 35: Blairmore Main Street Alberta. 
the economic climate and the arts/cultural/heritage milieu., ${ }^{24}$ Such initiatives will help to relocate and cultivate an 'ethos of sustenance' needed for further appreciation of the past through re-use in the present.

\footnotetext{
${ }^{24}$ Heritage Canada Foundation, Main Street: Past and Present. March 2009, 4.
} 


\section{Collective Memory}

\section{OF LOWERTOWN WEST}

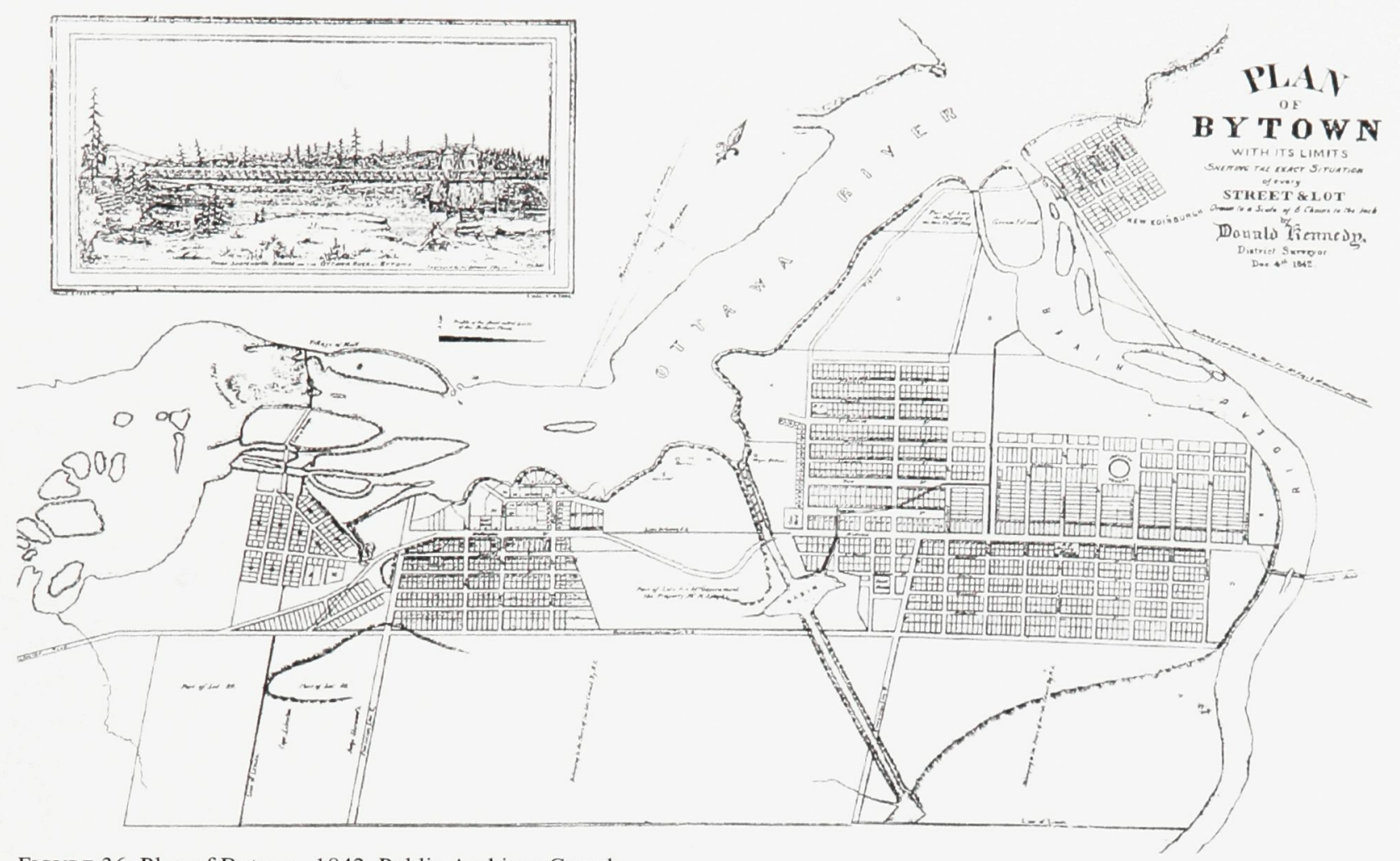

Figure 36: Plan of Bytown, 1842, Public Archives Canada.

A walk along Wellington Street past Parliament Hill and the Chateau Laurier, the red brick commercial buildings of Rideau Street, the limestone institutional buildings of Sussex Drive and finally the shops and stalls of the Byward Market, evidence of a previous time exists and is consistent with its present. However, the remainder of Lowertown, immediately north and east of one of Ottawa's busiest districts, referred to now as Lowertown East and West as divided by King Edward Avenue and bounded by the Rideau River, Canal and Street, is not as straightforward to read and to comprehend. Here one must actively investigate the history of Lowertown in order to understand how the area has changed and evolved over time. 
Lowertown East and West have not developed and prospered alongside the Byward Market district. Instead, it seems as if the area has been caught in a point of transition. While many would like to hold firm to the built heritage of Lowertown, to some respect it is this heritage that is helping to defer any further future progress. It is a situation that remains hard to mediate unless site stories are uncovered and conscious effort is made to awaken to the area through its existing buildings as well as its residents.

Lowertown was first placed in this transitory position immediately following the second world war. The 1950s and 1960s were seen as a period of "urban renewal" in the capital; it was a time to shed the past and welcome the future which promised to be brighter and better than ever. One of the most influential urban plans developed during this period was that of Jacques Greber in 1950 - a proposed official plan for the development of a National Capital Region. The Greber plan, modeled after those prepared and implemented in Europe, proposed new parkways, roads and bridges along with the upheaval of dozens of city blocks and the systematic demolition of hundreds of homes. Lowertown itself however was not immediately affected by Greber's proposed redevelopment.

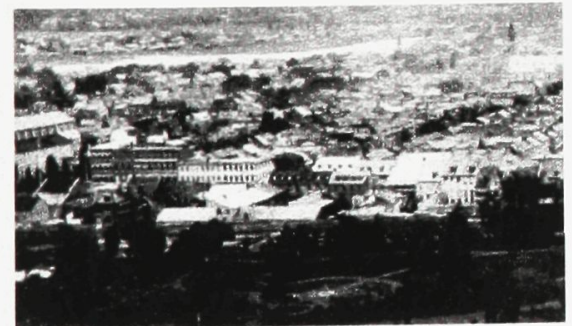

FIGURE 37: Lowertown, View from the Parliament (NAC C25559), 1892. Refer to Plate 1 for larger image.
In as early as 1954, the Housing Standards Board, began the demolition of nearly three hundred outbuildings and 'living units,' mostly in Lowertown East. (fIgure 37) While many of these homes were deemed to be in very poor condition, the total replacement of the area and displacement of the community seems quite extreme.

Lowertown West was not immediately affected by plans for urban renewal yet it was definitely pegged as an area for 


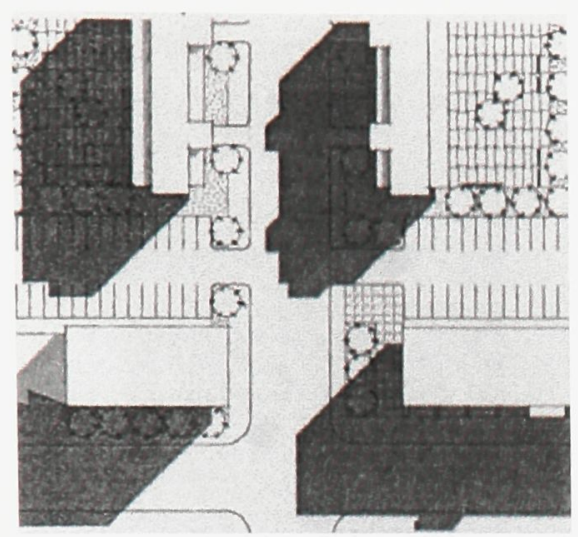

FIGURE 38: Lowertown West Urban Renewal Sketch for the corner of St. Patrick and Dalhousie Streets.

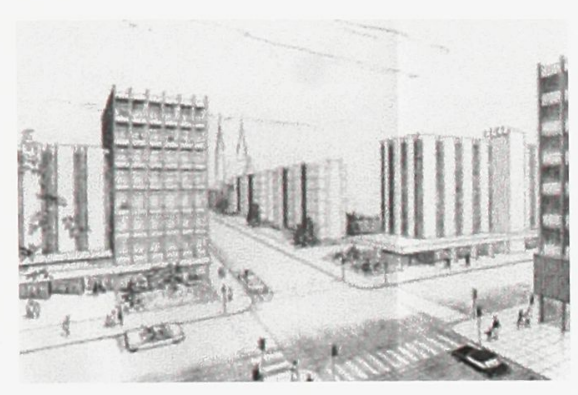

FIGURE 39: Lowertown West Urban Renewal Sketch for the corner of St. Patrick and Dalhousie Streets. gradual redevelopment and replacement. In 1967 the Department of Planning and Works published an Urban Renewal Study recommending Lowertown West remain primarily a residential community while increasing the density of development within the area. In addition, the study recommended provision be made for adequate public open space and that the reduction of unnecessary and undesirable through traffic also be considered. (FIGURE 38 \& 39) Although the study proposed to significantly alter the face of Lowertown West, it recognized the area to be one of the oldest in the city where "many manifestations of its history are still evident." Thus, the study recommended conservation be considered alongside the face of renewal; "wherever possible, worthwhile buildings of historic significance should be preserved and included in renewal schemes."2

The Lowertown West community largely opposed all renewal plans threatening to demolish their homes and businesses for proposed new development. As noted in the Lowertown West Heritage Conservation District Study, it was this resistance to top-down method[s] of 'blight removal' and the threat to established social communities [that] provoked years of protest that stalled the project [in 1968] and led to the creation of a mayor's committee on heritage. Its role was to recommend principles and measures for protection and restoration of the city's heritage. ${ }^{3}$

After spending four months drafting their initial report for then Mayor of Ottawa Pierre Benoit, the committee on heritage reacquainted themselves with an ethos of cultural and social sustainability that had been lost during the

\footnotetext{
${ }^{1}$ Planning Branch, Department of Planning and Works, Urban Renewal: Ottawa, Canada. (Ottawa, Ontario: Corporation of the City of Ottawa, 1967), 123.

${ }^{2}$ Ibid

${ }^{3}$ Michael McClelland, "Lowertown West Heritage Conservation District Study." May 1993, 32.
} 


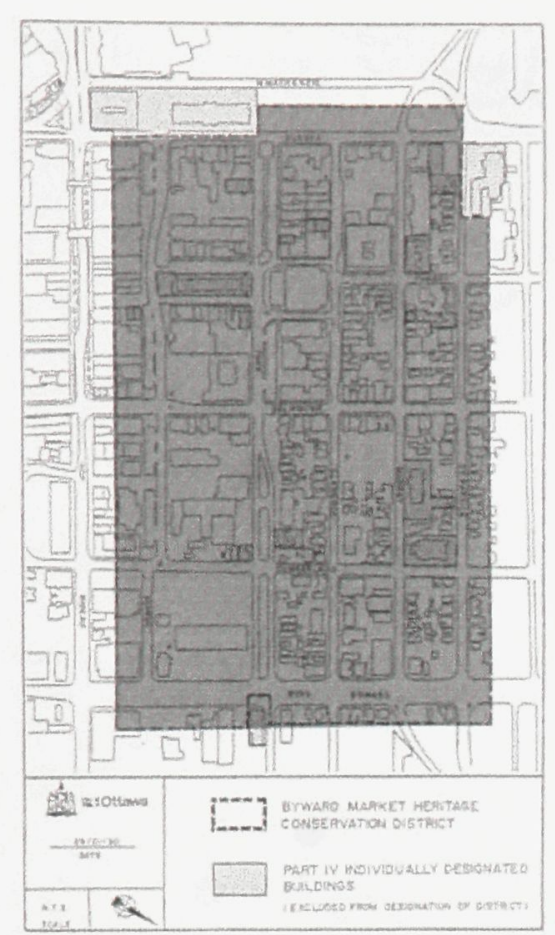

FIGURE 40: Boundary of the Byward Market Heritage Conservation District in 1990. (East / West Orientation)

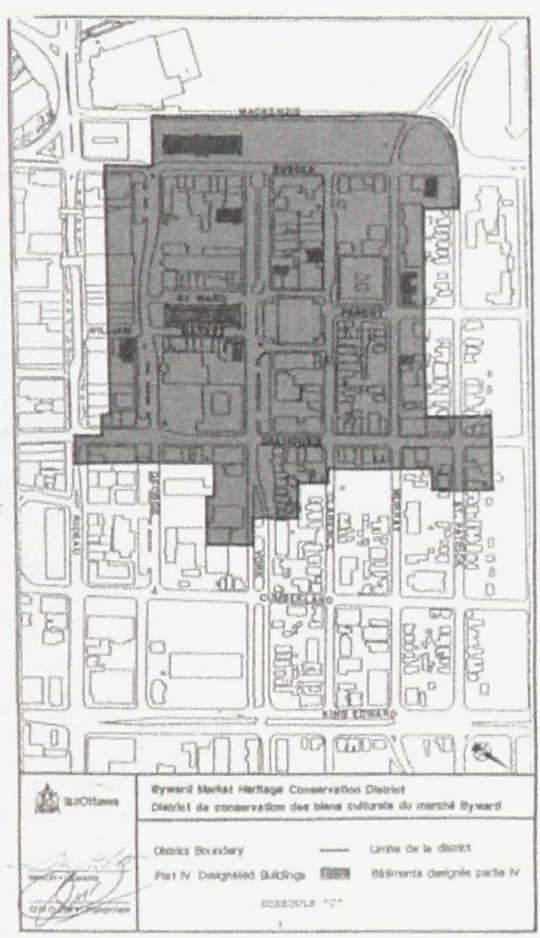

FIGURE 41: Boundary of the Byward Market Heritage Conservation District in 1991. (East / West Orientation) previous period of urban renewal. Here the committee sought to better understand how to acknowledge the value of the existing buildings within the city of Ottawa. The first page of the report reads,

the committee does not propose an objective, mathematical scheme for rating the value to the community of heritage buildings. Ultimately, decisions of preservation and development must depend on human evaluation in the circumstances of the time. Such decisions, while finally subjective, can still be better made if they take into consideration factors overlooked in the past. Indeed, a consideration of these factors might well lead to the kind of civic decision-making which has been lacking in the past. ${ }^{4}$

Specific considerations were made towards the end of the report for Lowertown West, recommending and encouraging development in the form of shops, boutiques, workshops, artists' quarters and restaurants while discouraging unnecessary demolition; "the city should use every moral force within its power to prevent irreparable loss on the eve of area development."

In the years that followed, consultative heritage studies continued and heritage planning policies were established and implemented, including the heritage designation of specific properties and districts under Part IV and Part V of the Ontario Heritage Act.

In 1990, the Byward Market Heritage Conservation District (HCD) was studied and designated. While the area of Lowertown West was initially within the proposed designation, this boundary was quickly retracted, considered to have "small pockets of heritage zoning" yet still generally

\footnotetext{
${ }^{4}$ City of Ottawa, Our Heritage: Report of the Mayor's Committee on the Heritage. November 1972,1 .

${ }^{5}$ Ibid, 39.
} 


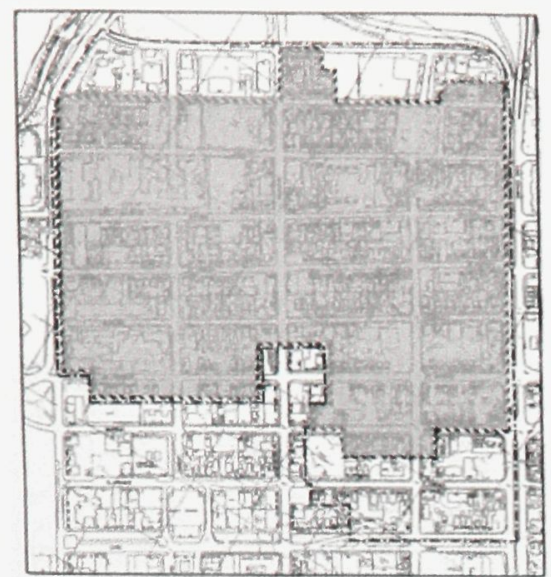

FIGURE 42: Boundary of the Lowertown West Heritage Conservation District in 1993. (North / South orientation)

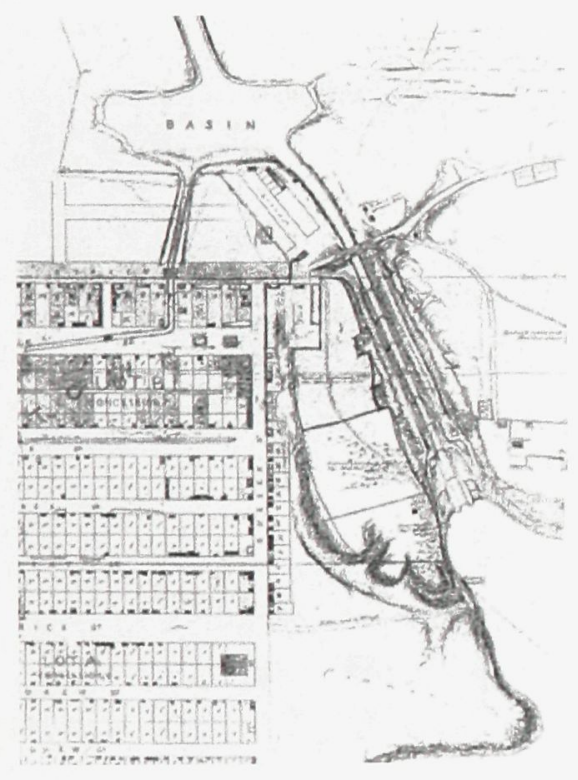

FIGURE 43: Lowertown West, Public Archives Canada, 1843. viewed by the City as "an area suitable for gradual clearance and new medium-rise development." (FIGURE 40 \& 41) In response to this omission, which in hindsight seems to be an appropriate move, the Lowertown West HCD was studied and further designated as early as $1993 .^{7}$ (FIGURE 42)

Although effort has been made since to conserve the built heritage of Lowertown West, residents continue to move out of the area and pedestrian traffic is extremely limited as through traffic along the wide one way streets of St. Patrick and Murray have taken over. In addition, buildings of modest historical and architectural value are becoming underused and abandoned over time as property owners and city officials cannot agree on how conservation and development can begin to work together in this area of the city.

I believe it is necessary to rediscover an 'ethos of sustenance,' for Lowertown West, to get past some of the standards, regulations and designations to remember why all this talk about heritage is so important to us in the first place.

As a first step, let us listen to the stories of Lowertown West together to discover pieces of its past, and present that I believe have laid the groundwork for a future of potential and of promise. Since its inception as a residential settlement from the British Survey of the town site in 1826-32, Lowertown West has catered to the romantic, the tragic, the heroic; the characters of these stories bring life to Lowertown. (FIGURE 43)

\footnotetext{
${ }^{6}$ Michael McClelland, 32

${ }^{7}$ The character of the Lowertown West HCD is inconsistent with that of the Byward Market and thus needs to be considered separately in order to garner appropriate conservation approaches for the area.
} 


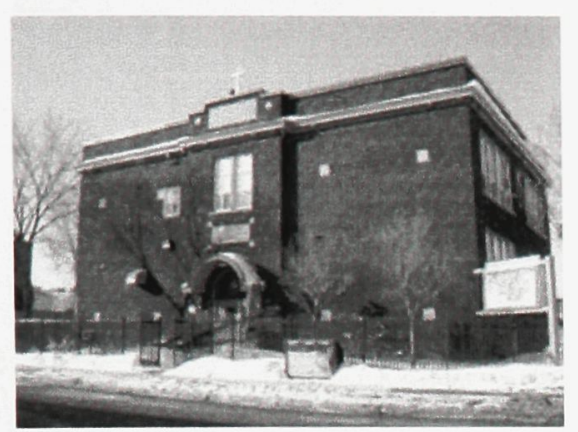

FIGURE 44: St. Bridget's School located at 233 Murray was originally constructed in 1924 as the English speaking Catholic school for boys. Today, the school houses volunteer and support services for Shepherds of Good Hope.

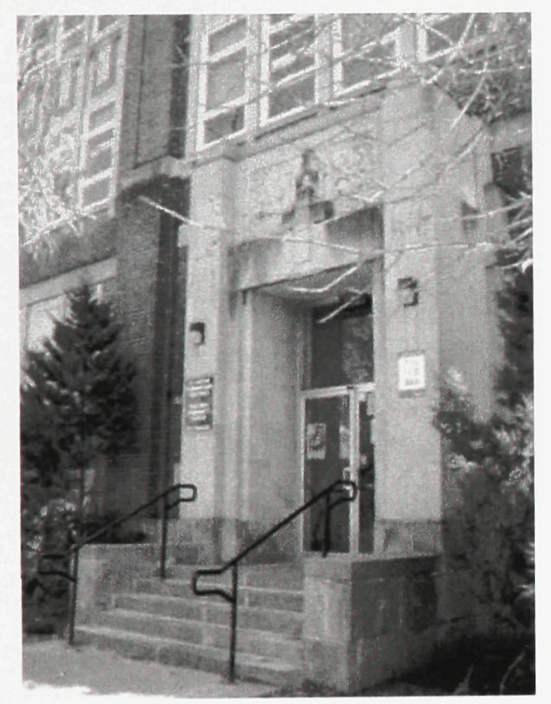

FIGURE 45: École Routhier located at 172 Guigues was originally constructed in 1932 . Today, the school operates as the Routhier Community Centre and is owned by the City of Ottawa.
Walking the streets, actively looking for and listening to these stories, I have come to realize the historic and architectural value of the area lies in the fact it was, and remains, the site of an interstice, an intersection of cultures and of communities. Since the inception of the Byward Market in the 1830s and the building of the Rideau Canal, Lowertown West has been a central settlement area and meeting place within the city of Ottawa. Yet all of these intersections have not been met without conflict. During these early years, Lowertown West was the home to the transient population of Ottawa, "riven with racial and religious rivalries that divided Irish Protestants from Catholics, and French from English, [who] kept up rowdy and lawless behaviour that fuelled Bytown's rough frontier reputation."

\section{Pea Soups, Jews and Dogans}

There are three schools on Angel Square. On one side is The School of Brother Brebeuf where all the French Canadians go. But nobody calls them French Canadians. Everybody calls them Pea Soups. On the second side of Angel Square is York Street School where Sammy and I go. Most of the people who go to York Street School are Jewish. I'm not. I'm not anything. But nobody calls them Jewish. Everybody calls them Jews. On the third side of the square is St.Brigit's School of the Bleeding Thorn where all the Irish Catholics go. But nobody calls them that. Everybody calls them Dogans. So four times a day most of the Pea Soups, Jews and Dogans try to cross Angel Square to get home or go to school. Young Tommy ... aka The Shadow

Although narrated in a fictitious and a presumably over exaggerated way, Angel Square, a children's novel by Ottawa elementary school teacher Brian Doyle, brings to light the

\footnotetext{
${ }^{8}$ Michael McClelland, 10.
} 


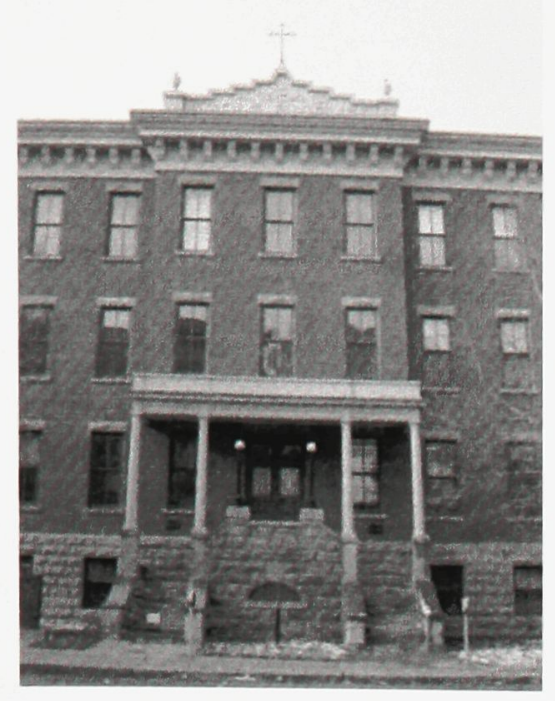

FIGURE 46: École Guigues located at 159 Murray was originally constructed in 1904. Today original architectural elements of the school have been restored and the building functions as a seniors residence.

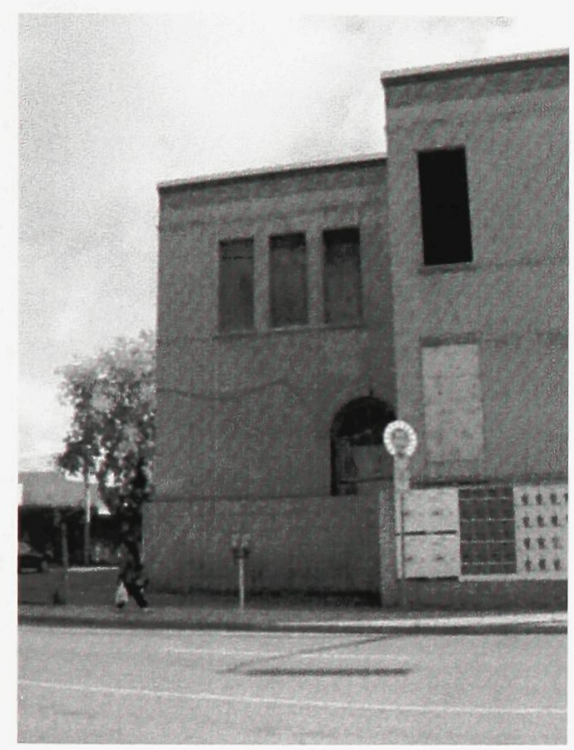

FIGURE 47: Our Lady School, 287 Cumberland was originally constructed in 1904 as the English speaking Catholic school for girls. Today the school is abandoned and boarded. often confrontational relationships of the Pea Soups, Jews and Dogans in Lowertown West through the eyes of young Tommy.

From the story, we gather each group had their own school, presumably their own church and other institutional and commercial buildings associated with their own cultures and beliefs.

Today, walking along the streets east of Dalhousie, we can begin to see further evidence of these cultures and communities in the remaining institutional buildings from the early twentieth century. Within the four blocks bounded by Guigues Street to the north, Murray Street to the south, King Edward Avenue to the east and Dalhousie Street to the west, four school buildings begin to bring life to young Tommy's story. (FIgure 44-47) We see École Routhier at 172 Guigues and École Guigues at 159 Murray where the Pea Soups would have attended. Similarly, we see St. Bridget's School at 233 Murray and Our Lady School at 287 Cumberland where the Dogans would have attended. Today all four schools have ceased to function as such. All of the schools have been reused for other purposes with the exception of Our Lady which remains in a transitory state.

Engaging with the physical remains of Our Lady School, we can still imagine how the young Dogans of Lowertown West might have lined up at the side door of the north façade after recess or the bustling activity that would have surrounded the building at the beginning and end of each school day. Yet, if the school is left in its current transitory state, any remaining connection to these stories and images will slowly fade and become confined to city archives where they do not actively help to sustain memories of the school. As stated in the 
Lowertown West HCD Study, schools are buildings of immense meaning and significance regardless of their historical and architectural value,

as buildings and institutions, schools provide continuity in a community. Patterns of movement and behaviour are associated with schools, and their place in daily life, that extend out into the streetlife of the district. They generate activities and collective memories that vitalize a residential area. The importance of these schools, irrespective of their historical significance, is their enhancement of community meaning and convenience. ${ }^{9}$

\section{ÉLISABETH BRUYÈRE AND The Grey Nuns of The Cross}

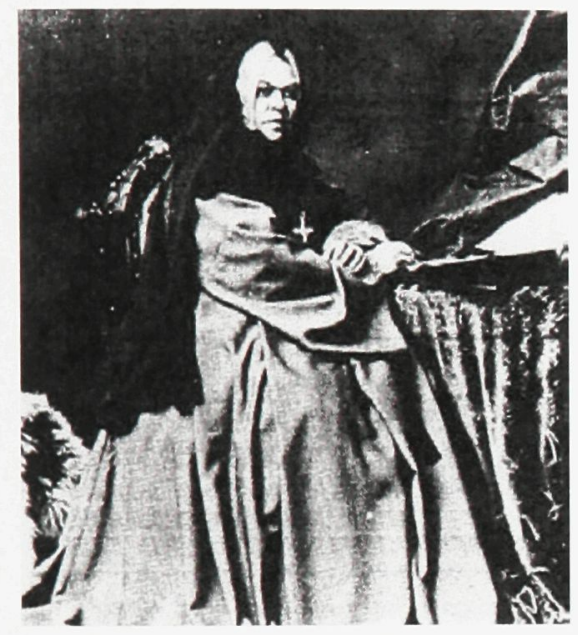

FIGURE 48: Mere Élisabeth Bruyère c. 1850

To some extent, it was these rather dynamic relationships between the Pea Soups, Jews and Dogans that triggered the Catholic church to become more involved in the affairs of Lowertown. This involvement was made in a dignified and respectful manner without imposing a system of beliefs on those in transitory positions.

Élisabeth Bruyère, born in 1818, was sent by the Ursuline Nuns from Montreal, with three of her sisters in February of 1845, to bring care and order to Lowertown. (FIGURE 48) Upon their arrival in Ottawa, the sisters established the Soeurs Grises de la Croi (Grey Nuns of the Cross) and wasted no time in pursuing their initial programme which included instituting a Catholic school for instruction in two languages, founding a Catholic hospital for health care without regard to age, sex, language, or religion and fulfilling any necessary charitable works that presented themselves. ${ }^{10}$

\footnotetext{
${ }^{9}$ Ibid, 21.

${ }^{10}$ Ibid, 18.
} 


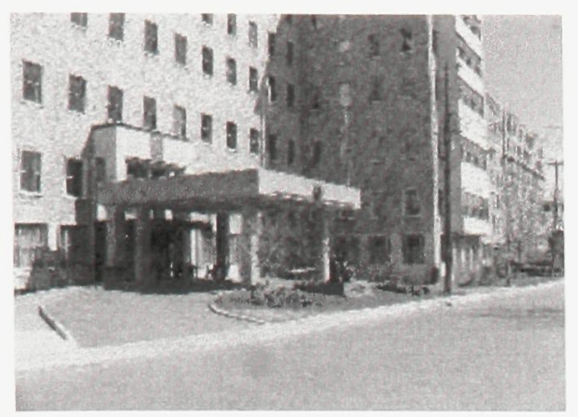

FIGURE 49: Élisabeth Bruyère Hospital, 43 Bruyère Street, Lowertown West.

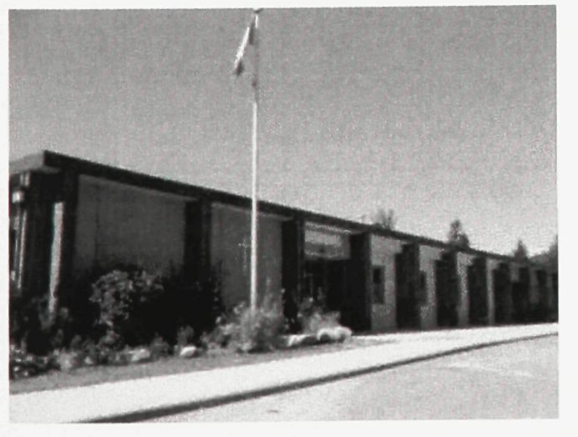

FIGURE 50: St. Brigid School located at 200 Springfield in New Edinburgh.
In the following thirty years, Bruyère established numerous charitable and educational works throughout Lowertown and "continually inspired her colleagues and associates with her zeal, her ardent faith, compassion, and enterprising energy." Although Bruyère passed peacefully in 1876, the work she started was furthered by her fellow nuns who continued to offer themselves as health care providers and teachers in the hospitals and schools of Lowertown. (FIGURE 49)

In 1860, Sister Rosalie Demers opened a two and a half storey school named Notre-Dame at 287 Cumberland to teach primary aged Lowertown girls how to read and how to write. In 1882 the French Canadian girls attending the school were transferred to École Guigues on Murray Street and in 1889 the school was renamed Our Lady School to reflect its English speaking pupils. At the turn of the twentieth century, the original stone school was replaced by the current two storey cast iron and masonry structure housing three classrooms per floor and twenty-five girls per room.

In 1964 the trustees of the Ottawa Catholic District School Board bought the two storey duplex at 324 St. Patrick, originally built in the late 1880 s, to enlarge the small school yard by demolishing the home in 1966. However, in 1971, Principal Sister Eleanor Hennessey and her 150 pupils moved to 200 Springfield, now called St. Brigid's School, where the students of Lowertown attend to this day. (Figure 50) Our Lady School was closed due to its still too small schoolyard, inefficient heating system and poor sound control. For the following decade, the school was sold numerous times until the present owner acquired the building in May of 1981. Since 1984, Our Lady School has been abandoned and boarded at the intersection of Murray and Cumberland Streets

\footnotetext{
${ }^{11}$ Ibid.
} 
Although the Grey Nuns of the Cross no longer inhabit Our Lady School at 287 Cumberland, their efforts can still be seen in Lowertown West and have more presence in the area than one might initially realize. 


\section{USE-VALUe AND RE-USE}

Use-value implies only this: that the thing takes place on the spot, and only there. - Denis Hollier

In the opening pages of Capital, Karl Marx identifies the substance and magnitude (quality and quantity) of value in the use of a commodity - "an object outside of us, a thing that by its properties satisfies human wants of some sort or another." From these pages, Denis Hollier believes usevalue for Marx "always refers in the final analysis to the needs and organs of a living body" and that the "use-value of the thing is therefore inseparable from its material support. It has no autonomous, independent existence. But it is at the same time a property of the thing that is only realized in the consumption, that is, the destruction, of the thing..."2

In The Use-Value of the Impossible Hollier exchanges commodities for architecture, to suggest the use-value of architecture according to Marx would rely on whether, and to what extent one is able to physically engage with it through specific functions. Thus if architecture is altered through restoration to represent a specific time period or architectural style, Marx would suggest its use-value is "exchanged" and "exhibited." Yet, if architecture ceases to serve a functional purpose, and no longer invites users to interact with it, Marx would claim its use-value, once present, is now lost.

Although one can appreciate the explanation Marx provides for the use-value of commodities, for architecture this approach still seems to be a quantifiable one. Whereas Marx would have one believe "the utility of a thing makes of

${ }^{1}$ Capital was originally published in 1867. Karl Marx, Capital: A Critique of Political Economy. (New York, NY: Random House Inc., 1906), 41.

${ }^{2}$ Denis Hollier and Liesl Ollman, "The Use-Value of the Impossible." October. Vol. 60. Spring 1992, 8-9. 
this thing a use-value," ${ }^{, 3}$ Hollier insists use-value, especially with regard to architecture, is about more than usefulness.

Relying on the writing of Walter Benjamin on the "authentic work of art," Hollier suggests architecture has use-value not only through its usefulness to a living body but also through its particularity.

The particular according to Hollier, references the "inexchangeable heterogeneity of a real, to an irreducible kernel of resistance to any kind of transposition, of substitution, a real which does not yield to a metaphor."4 The particular in architecture therefore refers to a specific space, place and time, ritual according to Walter Benjamin and is valued as an "authentic work of art." As the art-of-building, architecture of the particular is unique in its matter and material, as well as its memory and history; "it is not detachable from its context [and] can only be consumed on the spot." It is when this uniqueness is ignored, as in the case of Marx, that Karsten Harries believes an interpretation of reality has been made where "objective reason" becomes the "measure of what is real." What is "real" in this sense, is an augmented uni-focal existence where value through heterogeneity is largely ignored to support specific political, economic, social, environmental or cultural conditions.

For the following sections titled Exhibited Use-Value and No Use-Value, use-value as attributed to Marx is explained

\footnotetext{
${ }^{3}$ Karl Marx, 42 .

${ }^{4}$ Denis Hollier and Liesl Ollman, "The Use-Value of the Impossible." 11.

${ }^{5}$ Walter Benjamin, "The Work of Art in the Age of Mechanical Reproduction," Illuminations, trans. Harry Zohn (New York: Schocken, 1978), 223-224.

${ }^{6}$ Denis Hollier and Liesl Ollman, "The Use-Value of the Impossible." 8-9.

${ }^{7}$ Karsten Harries. "Space, Place, and Ethos: Reflection on the Ethical Function of Architecture." Artibus et Historiae. Vol. 5. No. 9, 1984, 165.
} 
further to demonstrate the existence of this approach today. Effort is then made to suggest a new way of functioning that gives priority to the sustaining value of the particular in architecture which affords it diversity.

\section{EXHIBITED USE-VALUE}

The museology of objects and of architecture removes them from their original context and negates part of their original use and meaning. Through primarily restoration practices, objects and architecture no longer serve the purpose for which they were originally formed and are made to acknowledge with the eyes, not with the hands. In the museum, the use-value of objects and architecture is exchanged for use-value that is only exhibited. Any sense of interaction between the user and the "thing" is repressed and exchanged for the program of the museum.

As noted previously by Marx, use-value is evaluated on the basis that it serves the needs of a living body. In the museum however, the needs of a living body are secondary to the objects being exhibited. Hollier suggests

taking the use-value of the exhibited objects (their function instead of their mere form) into account should lead to the introduction of the body into the space of the museum (opening the space of the museum to the world of the body and its needs). The central concept of this museology is that of bodily techniques. ${ }^{8}$

If objects are to be preserved for the historical episteme knowledge - they offer, one could encourage the interaction between the "thing" and the user in order to acknowledge not only aesthetic physicality but also sustaining value in functionality. Similarly, architecture representative of a specific time period or architectural style could engage users instead of solely exhibiting a former use and aesthetic by repressing the secondary present. In this way, it is more

\footnotetext{
${ }^{8}$ Denis Hollier and Liesl Ollman, "The Use-Value of the Impossible." 9.
} 
meaningful and efficient to learn from the past by actively engaging with it.

Although it is understood select properties need to be carefully administered for the historical episteme they offer, most can necessarily continue to be used according to the needs of the present community to which they belong. Kevin Lynch believes,

restoration is unjust unless present residents can choose to remain in the renewed structures. If they do, renewal is a different affair since existing residents see different values and a different history in the old houses. Frequently, it was their ancestors who actually built the fine houses, and in more recent years the history of the place has surely been their own. ${ }^{9}$

Through Lynch, one understands it is the sense of being in the present that is, in fact, what is worth sustaining. In this way, historical episteme is not only seen but experienced. Users touch, feel and use objects and architecture of a previous time and style and, in so doing, place the past, present and future in a dynamic dialogue.

\section{No USE-VALUE}

With reference to Marx, Hollier suggests "use-value cannot outlast use [and thus] vanishes at the moment it is realized." 10 Without a functional purpose and thus the presence of a living body, Marx would suggest architecture becomes a form, an object in the landscape. This form / object, now abandoned, no longer holds an ethical function. Marx would say the abandoned has potential use-value but at present has no use-value.

According to this objective definition, if architecture ceases to have a function, and thus an ethical function, it is no longer

\footnotetext{
${ }^{9}$ Kevin Lynch, What Time is This Place? (Cambridge, MA: MIT Press, 1972), 42.

${ }^{10}$ Denis Hollier and Liesl Ollman, "The Use-Value of the Impossible." 8.
} 
useful. And if this architecture is considered useless, why should it not be discarded?

Although these sites 'in-transition' are often perceived to have less quantifiable use-value, it is not appropriate to suggest they presently have no use-value. Even though the abandoned no longer assumes daily functions by engaging users, the abandoned does bear relevance in the particularity of its matter and its memory. Yet it is only through the realization of new use that the abandoned can again become relevant in function. In most cases use-value does exist in the potentiality of re-use by present and future communities.

\section{Sustaining USE-VALUe IN RE-USE}

In The Death and Life of Great American Cities, Jane Jacobs insists on the sustaining nature of the existing: "old ideas can sometimes use new buildings [but] new ideas must use old buildings."11 Jacobs believes the re-use of the old and abandoned makes diversity possible within a district which is ultimately needed for the area to thrive and to sustain itself. Jacobs explains how use-value is cyclical in nature as each generation appropriates new uses for existing objects and architecture.

Time makes the high building costs of one generation the bargains of a following generation. Time pays off original capital costs, and this depreciation can be reflected in the yields required from a building. Time makes certain structures obsolete for some enterprises, and they become available to others. Time can make the space efficiencies of one generation the space luxuries of another generation. One century's building commonplace is another century's useful aberration. ${ }^{12}$

\footnotetext{
"Jane Jacobs, The Death and Life of Great American Cities. (New York, NY: Random House Inc., 1961), 188.

${ }^{12}$ Ibid, 189-190.
} 
Within her writing, Jacobs explains quite explicitly how a city needs primary mixed uses, small blocks, aged buildings and concentration in order to have the diversity necessary to provide social sustenance for cities and an ethos of the same. This quest for social sustenance however does not seem to resonate with the present definition of sustainability that favours performance-based approaches driven by quantitative objectives. Although these initiatives are most certainly part of an 'ethos of sustenance,' they do not singularly define it. Mark Kessler believes the present definition "reveals the antiquated, convoluted and limiting nature of present criteria and standards." 13 Kessler insists the city is a "man-made version of a natural resource" with "a common heritage that includes features unique to its culture and history." 14 Here Kessler begins to use quantifiable language to explain qualitative value.

Kevin Lynch similarly recognizes the usefulness of diversity within the built environment in providing sustenance for cities, towns and communities:

The best environment for human growth is one in which there are both new stimuli and familiar reassurances, the chance to explore and the ability to return. In a mobile age young people, at least, must learn the skills of adaptation: how to acquire new information, how to relate to strangers, how to make choices. But they must have a home and a center somewhere, a secure base from which they can open out. ${ }^{15}$

Ironically, the secure base, Lynch describes is often found in the most vulnerable architecture. Here the old and the abandoned become footholds for potential re-use and have

\footnotetext{
${ }^{13}$ Mark Kessler. "Sowing Seeds of Diversity: The Influence of Sustainability on Adaptive Reuse.” Washington D.C.: ACSA Press, 2009, 514.

${ }^{14}$ Ibid, 512. Throughout his paper, Mark Kessler, an architecture professor from the University of California, relies on the industrial and garage structures built in San Francisco in the 1910s and 1920s as an example of a common building type that is both threatened and easily adaptable for new uses.

${ }^{15}$ Kevin Lynch, 204.
} 
the ability to provide sustenance through age and use grounded at a particular location.

In order for an 'ethos of sustenance' to become more apparent through values-based approaches as well as performance-based initiatives, it is necessary for architects to advocate on behalf of the city. This is not to say the architect should attempt to possess ultimate control over a rehabilitation project by implementing his / her own ideas without consulting communities and those with vested interests in the site. In this way the architect may think he / she is serving the best interests of his / her client but if this work is conceived in contrast to what is needed and possible, conflict will ensue. Instead, as the mediator and leading professional, it is suggested the architect be prepared to consult the surrounding community to determine how to best provide for current and potential future needs. Accordingly, it is through this consultation that any new use and thus, reuse is realized. For when existing buildings are given new private and public functions, in consultation with current and potential users, they become engaging sites where users are encouraged to interact with each other. Each site in its own right thus has the potential to be heterologous to the events of the particular.

\section{Social Sustenance: THROUGH Housing}

By acknowledging the specific needs of a living body, one can suggest new uses for the old and the abandoned. Today within North American cities and towns, buildings are abandoned with no supposed usefulness while thousands of individuals and families find themselves on waiting lists for 
affordable housing. ${ }^{16}$ Is it not possible to use this abandoned building stock to rehabilitate those communities and individuals in desperate need of shelter and services and, in so doing, acquire new value through a new use? Already in the 1960s when Jacobs is writing, she acknowledges the potential of using old buildings for "many varieties of middling-, low- and no-yield diversity." 17 By providing shelter and services, effectively support and sustenance, for the destitute and vulnerable in society, life is brought back to these structures. Here, support takes the form of respect for those individuals and buildings at the threshold between further decay and new life.

In October of 2007, activists within the City of Toronto proposed the city enforce a "Use It or Lose It" bylaw that would make it easier for the city to expropriate abandoned buildings to be converted into affordable housing. The bylaw suggested property owners either use their sites responsibly or lose their privileges to own private property. ${ }^{18}$ Within the city and inner suburbs, activists mapped nearly thirty abandoned buildings that could be used for affordable housing. In June of 2008, Abandonment Issues, a Toronto based coalition of housing activists, issued a report suggesting a potential policy framework for the new bylaw. (FIGURE 51) To this day, the bylaw is still being reviewed by the City of Toronto.

In other parts of Canada "Use It or Lose It" bylaws have already been implemented. The City of Winnipeg adopted a

\footnotetext{
${ }^{16}$ In the city of Ottawa alone, there is backlog of more than 9,500 applications for affordable housing, including requests from large families with children.

${ }^{17}$ Jane Jacobs, 199

18 CBC News. Turn Abandoned Buildings into Affordable Housing: Activists October 29, 2007.
}

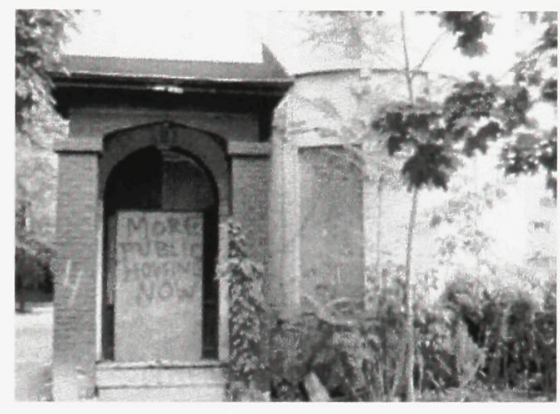

FIGURE 51: The Cover of "From Abandonment to Affordable Housing," dated June 16, 2008, Abandonment Issues. 
comprehensive "Vacant and Derelict Buildings" bylaw in 2004, while the City Council of Victoria began to consider a draft bylaw of the same nature in late 2007.

While the City of Ottawa cannot boast the use or consideration of such a bylaw, the city is currently reviewing a "Demolition By Neglect" bylaw that would effectively force owners of heritage properties (individually designated or within heritage conservation districts) to maintain their buildings or have the municipal government intervene to complete any necessary work. (FIgURE 52 \& 53) This bylaw could help to ensure present and future use as opposed to leaving properties vacant to deteriorate, to be demolished and to subsequently be built over. By considering the implementation of such legislation, the city sends the message that they are concerned for the future of the existing building stock, especially those buildings deemed to be historically and / or architecturally significant.

In conjunction with this work, effort could subsequently be made to offer shelter and services for those in need within the city. Currently, it seems unfortunate buildings are allowed to deteriorate, with the prospect of new development, while those in need will not be able to afford space in the proposed new structures. In these cases, social sustenance is not provided for cities, towns and communities, instead economic sustenance is provided for property owners and developers who allow these buildings to remain underused and under maintained.

The Local Architectural Conservation Advisory Committee (LACAC) recommended approval of the proposed bylaw this past March. Currently this issue is being examined by the Planning and Environment Committee. Recommendations

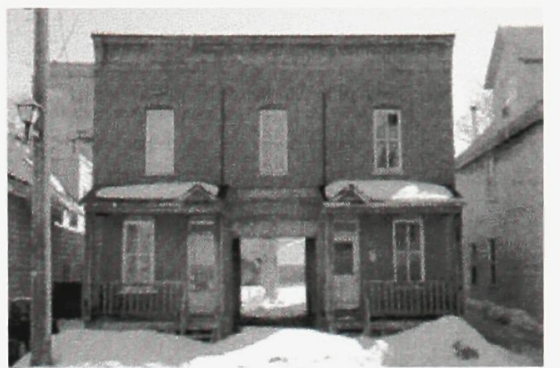

FIGURE 52: 52-54 Bolton St. resides within the Lowertown West HCD - its owner would like to have it demolished.

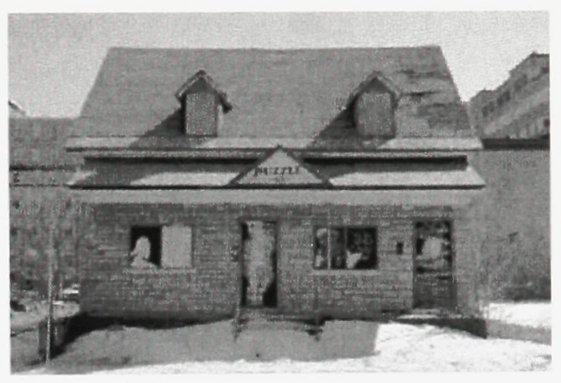

FIGURE 53: 78-80 Bolton St. resides within the Lowertown West HCD - its owner would like to have it demolished. 
will be presented to Ottawa City Council this fall, 2009.

\section{AND The ArTs}

The old and the abandoned have similarly been able to provide social sustenance for cities, towns and communities in the way of affordable studio space for artists. Especially when first starting out, artists often do not have the means or wants to occupy high rent space in the center of a city. Instead, low rent properties, often located at or in marginal threshold conditions are acquired as studio and gallery space to pursue creative interstitial endeavours. The art created in these spaces is often unique and heavily based on the surrounding social conditions of this specific margin or threshold.

Notable programs are now in place throughout Europe and North America to acquire abandoned buildings for artists in the form of work, instruction, exhibition and gallery spaces. In New York City, art collector and curator Alanna Heiss founded The Institute for Art and Urban Resources Inc. in 1971, with the hope to re-use the abandoned spaces of New York as artist studios and galleries. One of her most notable efforts includes the re-use of a public school building (P.S.), originally constructed between 1890 and 1900 in Long Island City, NY as the P.S.1 Institute of Contemporary Art. (FIGURE 54) After its first exhibition, seminal Rooms, in 1976, which transformed the interior of the building into site-specific art installations, the institute was further used for studio, performance and exhibition spaces for the next twenty years before being significantly renovated. Today, the institute is now an affiliate of the Museum of Modern Art (MOMA) and continues to act as "a catalyst and an advocate for new ideas, discourses, and trends in contemporary art, actively pursu[ing] emerging artists, new genres, and adventurous new

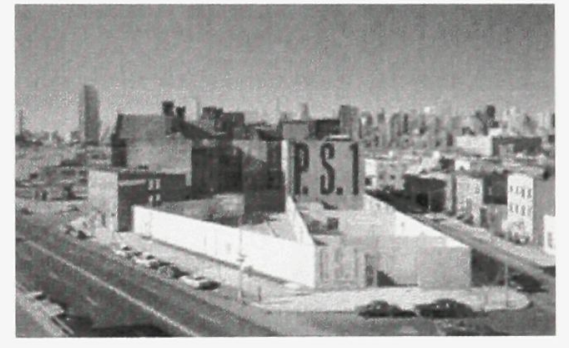

FiguRE 54: P.S.1 Institute of Contemporary Art, Long Island, NY.

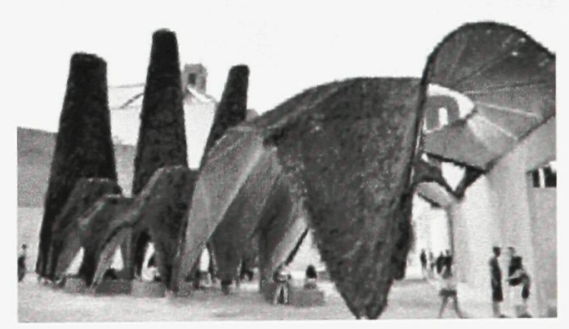

FIGURE 55: "Afterparty." by architecture firm MOS, 2009 Young Architects' Program Winning Entry, P.S.1 Institute of Contemporary Art, Long Island, NY. 
work by recognized artists in an effort to support innovation in contemporary art." ${ }^{19}$ (FIGURE 55)

As perceptions of what it means to be sustainable continue to shift from strictly performance-based approaches to valuesbased conservation, abandoned sites will continue to be reused for studio, performance and gallery spaces within North America. Since the early 1990s in the city of Toronto, Artscape, a non-profit urban development organization has been revitalizing buildings and neighbourhoods by providing "affordable space for creativity while generating positive cultural, economic, social, and environmental impact." ${ }^{20}$ In November of 2008, Artscape reopened the doors of the Wychwood Toronto Transit Corporation (TTC) Repair Barns in the St. Clair and Christie neighbourhood. The five barns, originally constructed between 1913 and 1921 were used by the City of Toronto until the mid-1980s when they were left vacant. (FIGURE 56) In 2004, Artscape was selected to rehabilitate the barns through community consultation and feasibility studies. Today the barns are home for nearly 50 artists (26 artists and their families as well as 11 individual artists) and nearly a dozen non-profit art and environmental organizations. (FIGURE 57, $58 \& 59$ ) It is hoped the work of organizations such as Artscape will continue to re-use underutilized and abandoned buildings within Toronto and other cities in North America to realize the immense potentiality and use-value these sites have.

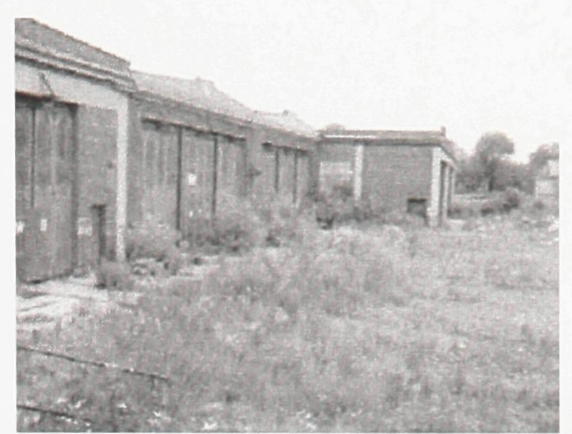

FIGURE 56: Former Wychwood Toronto Transit Corporation Repair Barns, an abandoned complex before being rehabilitated by Artscape, Toronto, ON.

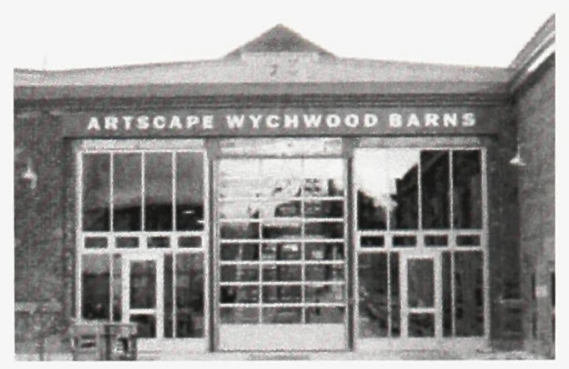

FiguRE 57: Exterior Barn 2, Artscape Wychwood Barns, Toronto, ON.

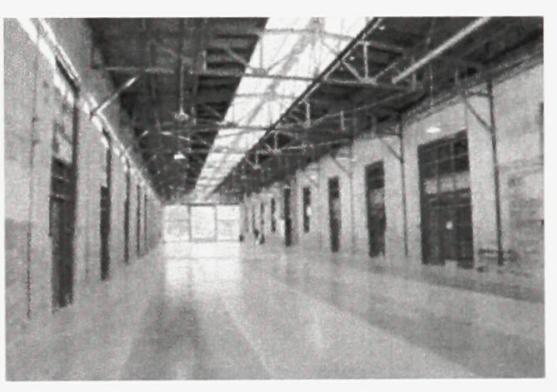

FIGURE 58: Interior Barn, Artscape Wychwood Barns, Toronto, ON

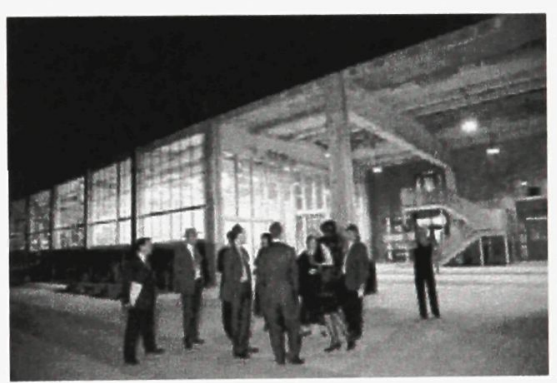

FIGURE 59: Exterior Barn 2, Artscape Wychwood Barns, , Toronto, ON.

\footnotetext{
19 “About." P.S. 1 Institute of Contemporary Art (MOMA). $<$ http:www.psl.org/about> (May 2008).

20 “Artscape Wychwood Barns." Artscape. <http:www.torontoartscape.on.ca/placesspaces/artscape-wychwood-barns $>$ (May 2008).
} 


\section{Use-Value and Re-Use}

\section{IN THE ARTS AND HOUSING}

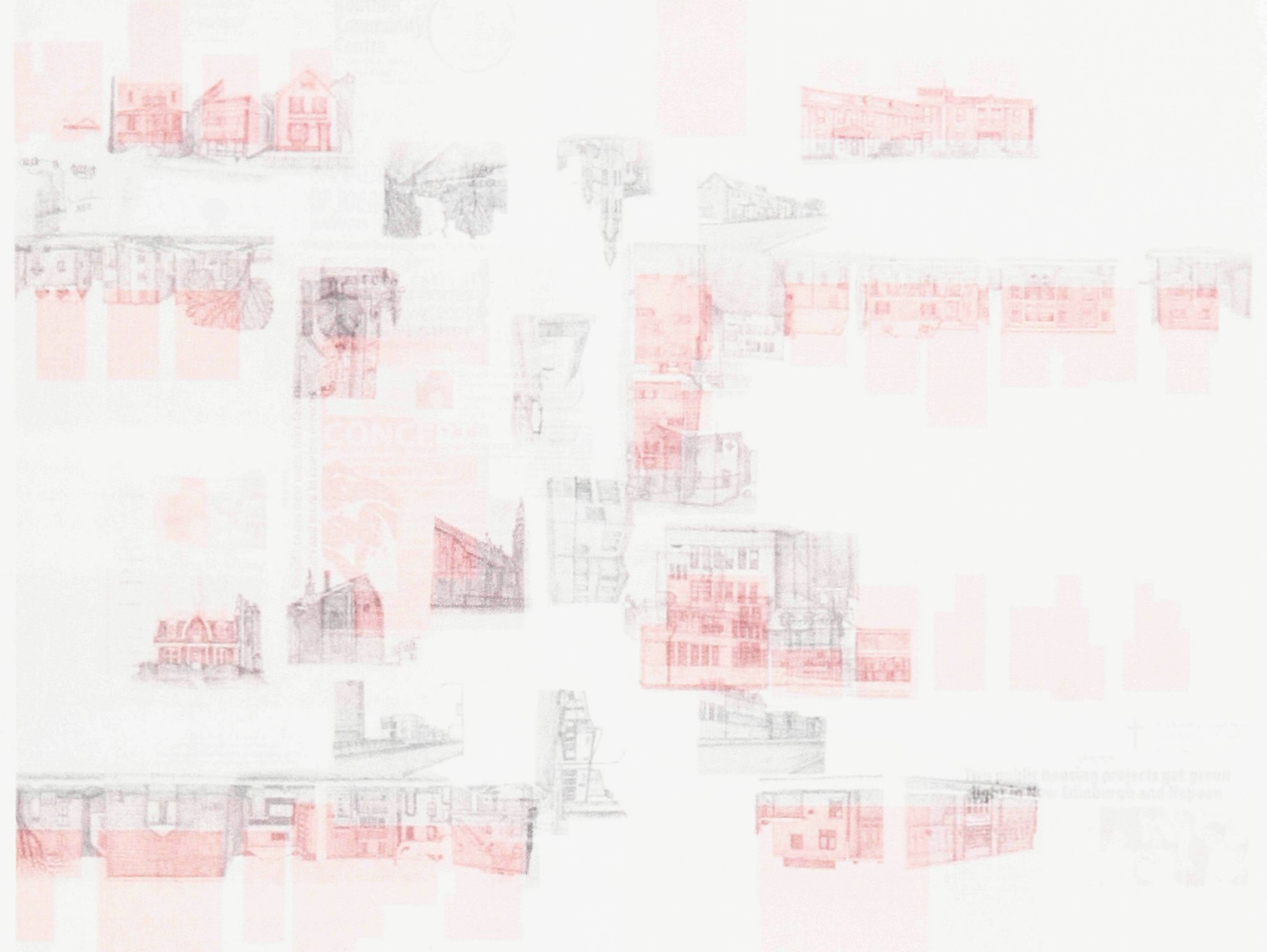

FIGURE 60: Site Palimpsest: perceptions and use of the juncture between St. Patrick, Murray and Cumberland Streets today. Refer to Plate 2 for larger image.

Our Lady School has immense use-value in the potential of its re-use according to its matter and materials, memory and history. However in order to formulate a proposal for how this use-value might be sustained in re-use, it is necessary for us to visualize how the site and surroundings are in fact perceived and used today.

The picture I paint for you now is a layered image based on events attended, experiences had and relationships formed that have allowed me to become personally familiar with the buildings and residents at this particular juncture in Lowertown West. 


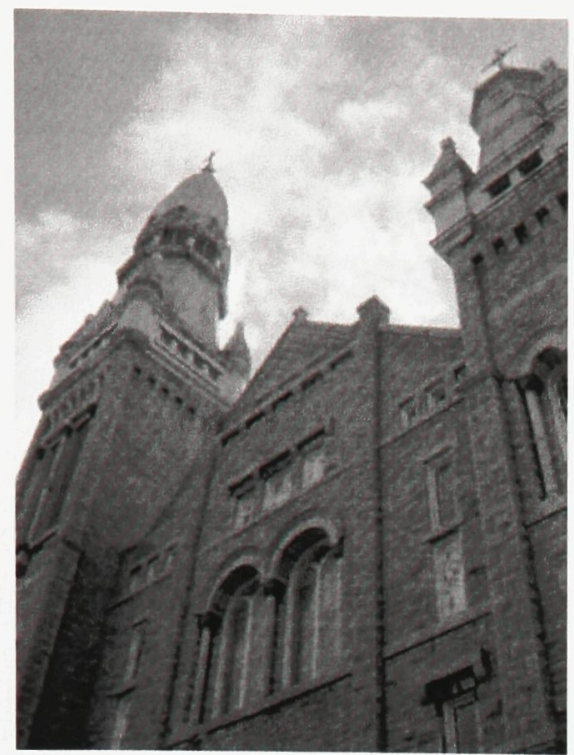

FIGURE 61: North façade, Saint Brigid's Centre for the Arts and Humanities, home of the National Irish Canadian Cultural Centre.

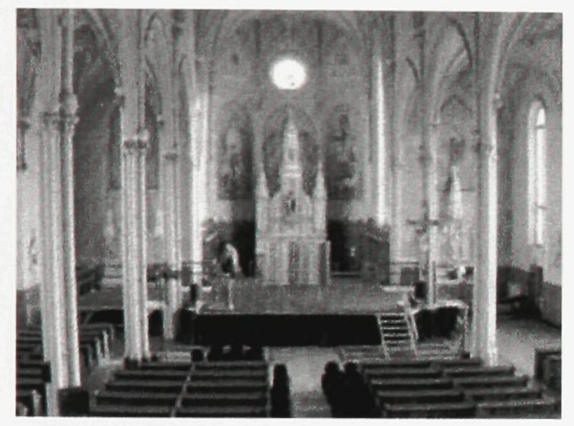

FIGURE 62: Interior facing south towards main alter, Saint Brigid's Centre for the Arts and Humanities, home of the National Irish Canadian Cultural Centre.

\section{SAINT BRIGID AND SHEPHERDS}

Located at 314 St. Patrick, St. Brigid's Centre for the Arts and Humanities stands as a reminder of the past and a suggestion of a new future to sustain its cornerstone position. (FIGURE 61 \& 62) Until being deconsecrated, St. Brigid's Roman Catholic Church catered to the spiritual and physical well being of residents in Lowertown West. As a Catholic institution in Lowertown, St. Brigid's was also directly connected to the works of The Grey Nuns of The Cross, Our Lady and St. Bridget schools and numerous charitable organizations and institutions.

In the late $1800 \mathrm{~s}$ the English-speaking Irish parishioners of Notre Dame Basilica, 385 Sussex Drive and Ste. Anne's, 528 Old St. Patrick Street, secured approval from the Archbishop to build a new church in Lowertown. As early as 1888 a committee approached prominent local architect John R. Bowes for plans and on Sunday August 3rd of 1890 Archbishop Duhamel blessed St. Brigid's Roman Catholic Church.

The church was built primarily for and by Irish Canadian tradesmen, lumbermen and laborers involved in building Lowertown and the Rideau Canal. The church itself was built of modest materials in a composite style - rubble limestone

\footnotetext{
${ }^{1}$ A careful look at the history of Lowertown will reveal the choice of St. Brigid as the patron saint for the church as a perfect choice. St. Brigid is regarded as the patroness of Ireland - Mary of the Gael. St. Brigid was known for helping those less fortunate, she often gave away milk and butter from the dairy where her mother worked; she even gave her father's prized sword to a leper. St. Brigid was the goddess of fire, whose manifestations were song, craftsmanship and poetry, which the Irish considered the flame of knowledge.

${ }^{2}$ Architect John R. Bowes was a prominent architect in Ottawa in the late $19^{\text {th }}$ century. His father was James Bowes who worked under Thomas Fuller. The contractor for the church was J.J. Lyons. The sub contractors were Messrs. Douglas and Haines for the galvanized ironwork on the roof, Mr. Daley for the frescoing of the ceiling and painting of the woodwork. Messrs. Dewis and Chandler for the plumbing and heating. The stained glass windows were prepared in Montreal by Messrs. Castle and Sons. Michael Newton. Lower town Ottawa. Vol.1 (Ottawa, ON: National Capital Comission, 1979) , 500.
} 


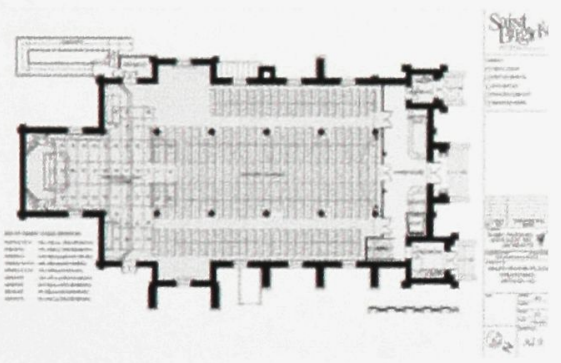

FIGURE 63: Concert Hall Plan, Saint Brigid's Centre for the Arts and Humanities, home of the National Irish Canadian Cultural Centre, Barry Padolsky Architects

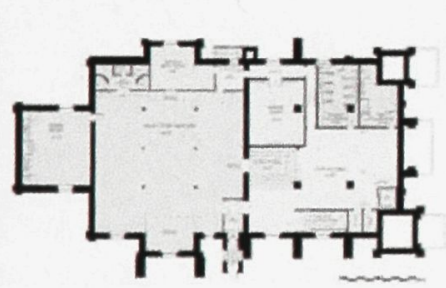

Figure 64: Basement Plan, Saint Brigid's Centre for the Arts and Humanities, home of the National Irish Canadian Cultural Centre, Barry Padolsky Architects. with cut stone dressing for the exterior and wood for the interior; Romanesque in the arches of the front north facade and Gothic Revival in its asymmetrical towers. Over the years, the church has become known as the worker's church.

Although the interior of the church was made completely of wood, it was painted intricately to appear as marble and other precious materials. Biblical scenes and Christian motifs also adorn the church walls. The concrete buttresses on the east side of the church were added c.1968 to support the fan vaulted ceiling that caused the east walls of the church to sink.

Throughout the late twentieth century, the number of Englishspeaking Catholic parishioners declined as demographics shifted. With fewer parishioners it was difficult to garner financial support for the physical maintenance of the building. In the 1960 s the church paintings were completely covered over due to budgetary restraints and the church bell was also sold. Further decline in attendance and lack of funds to maintain the building and clergy seemed reason enough for the Archbishop to recommend the church be deconsecrated. Parishioners were obviously quite upset with the decision made by the Archbishop and took various forms of action in an attempt to keep the parish. However on September $16^{\text {th }}$ of 2007 , St. Brigid's church held its final mass.

Put up for sale shortly thereafter, the former church building was purchased by fellow Irish Canadians in Ottawa with the intent to physically maintain the cathedral building according to its heritage designation and conservation easements,

\footnotetext{
${ }^{3}$ The Ontario Heritage Trust secured a heritage easement to conserve the building in 1992. The City of Ottawa has also designated the cathedral under Part IV of OHA.
} 


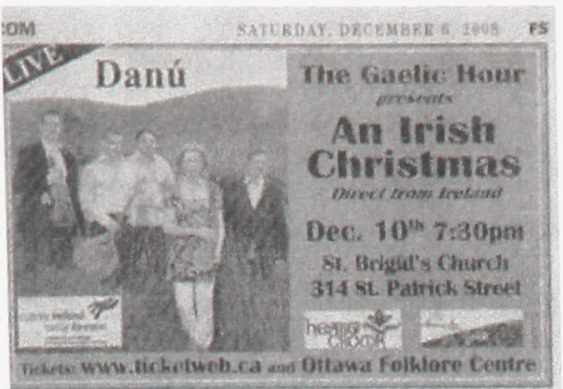

FIGURE 65: "An Irish Christmas" concert by Danu from Ireland as advertised in the Ottawa Citizen December 6, 2008.

December 10, 2008

Today I visited Saint Brigid's in the evening for a concert. I thought it would be helpful to see how a concert is put on at this location. Upon arrival at the church, I took a look at the architectural plans that had recently been received from local architect Barry Padolsky. The plans for the Centre seemed to be more ambitious than I had initially realized. I walked into the sanctuary of the church and sat down in a pew towards the back on the east side - unfortunately it is hard to see the stage from the flanking aisles due to the large centrally placed columns. As the concert began, the music resonated beautifully within the church. The audience was relatively modest in size and there was a lighthearted atmosphere where I felt to be in the company of friends.

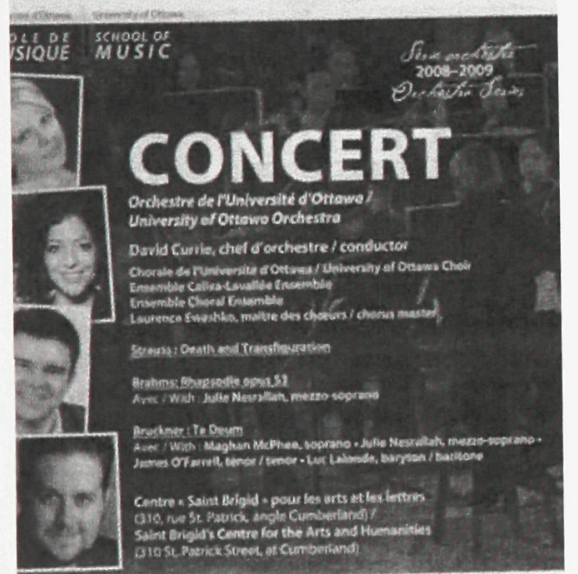

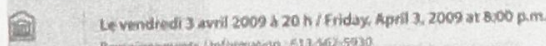

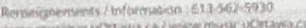

FIGURE 66: 2008-2009 Concert by the University of Ottawa Orchestra, programme from April 3, 2009.

Three hundred musicians from the University of Ottawa took to the stage for their annual concert. while adaptively re-using the site as Saint Brigid's Centre for the Arts and Humanities - Home of the National Irish Canadian Cultural Centre. (Figure 63 \& 64) Under the direction of local conservation architect Barry Padolsky, renovations have been ongoing since September of 2008. During this time, organizers at Saint Brigid's have rented out the former church sanctuary (Eiren Concert Hall) and basement (Emerald Club multi-purpose space) for numerous events to generate interest and funds for the re-use project. The Eiren Concert Hall boasts a new $40 \mathrm{ft} \times 28 \mathrm{ft}$ stage with seating capacity for 700 . With its wooden interior, the acoustics of the hall have been praised and numerous $\mathrm{CBC}$ recordings have taken place here as a result. The Emerald Club multipurpose space comfortably seats 150 and now reveals the original limestone walls, previous covered by drywall partitions to designate space for Sunday school classrooms. Notable events held here in 2009 include the Ottawa International Writer's Festival in April and Chamberfest in August. Over the past year I have had the pleasure to attend numerous performances and events at the Centre. (FIGURE 65

69)

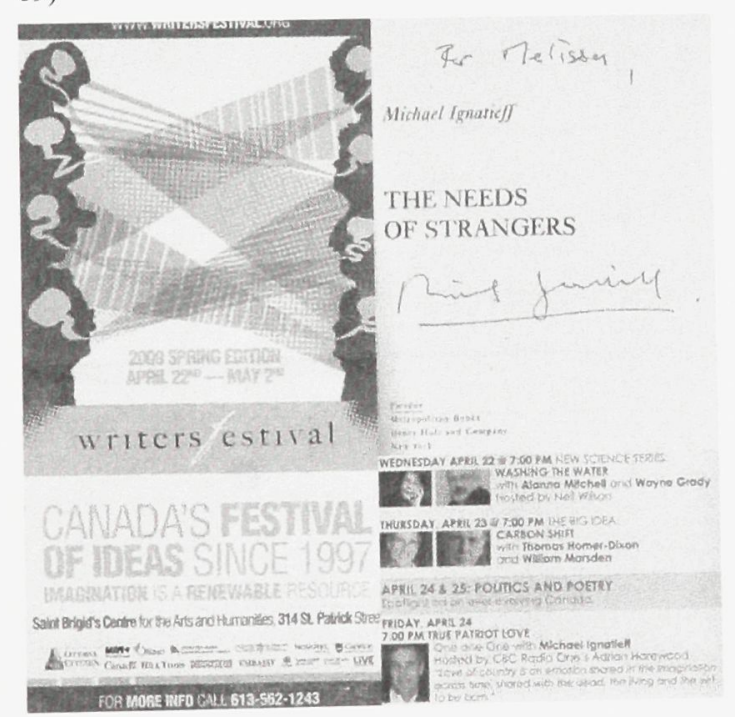

Figure 67-69: 2009 Writers Festival Programme; 2009 Writers Festival Programme featuring Michael Ignatieff April 24, 2009; Signature of Michael Ignatieff from book signing after presentation. (counter-clockwise from left)

After being interviewed by CBC Radio One's Adrian Harewood, Michael Ignatieff signed copies of his new book True Patriot Love in the Emerald Club. At this time 
visitors could also enjoy a photo exhibit entitled Beautiful Destruction by Louis Helbig.

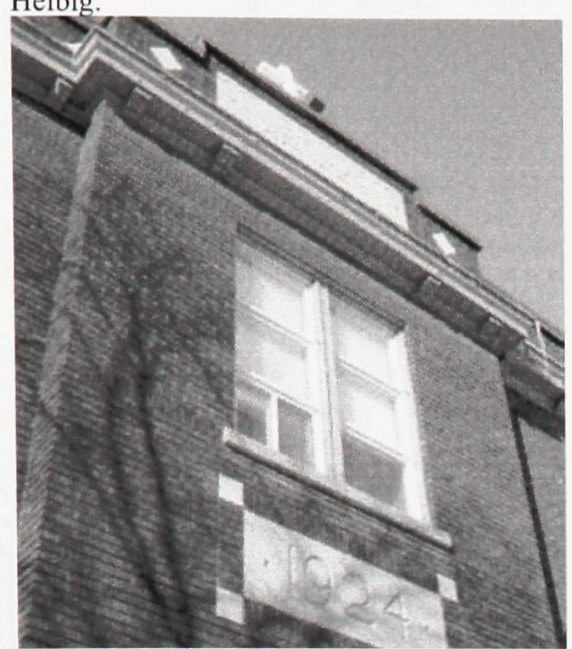

FIGURE 70: 233 Murray Street, former home of St. Bridget's School currently houses Volunteer and Support Services for Shepherds of Good Hope.

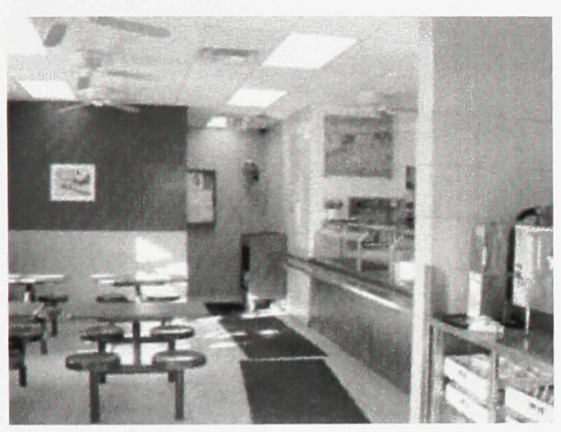

FIGURE 71: Soup Kitchen at 233 Murray Street serves nearly 400 meals per day.
Down the street from the Centre at 233 Murray there is also evidence of Christian foundations in St. Bridget's School where the English-speaking primary aged boys of Lowertown West once attended. (FIGURE 70) Dogans were taught by the Christian Brothers at this location from 1924 to 1971. In the 1950s the school taught both the boys and girls of Lowertown from grade four to grade eight, while primary aged children attended Our Lady. In 1971, the school closed as such and students were sent to the newly constructed St. Brigid School at 200 Springfield in New Edinburgh. When in operation, each school kept close ties with St. Brigid's parish - one of the shared parish-school activities being the celebration of the feast of St. Brigid on February $1^{\text {st }}{ }^{4}$

When St. Bridget's school was closed as such its future was uncertain. Today however it is fitting to see the school building function as the home of the Christian support organization Shepherds of Good Hope, incidentally first established in the basement of St. Brigid's Parish in 1983. The Shepherds have occupied St. Bridget's school at 233 Murray since October of $19855^{5}$ (FIGURE 71)

Shepherds of Good Hope is a social outreach organization that offers services for the homeless in Ottawa "by providing support, being non-judgmental, and easing

\footnotetext{
${ }^{4}$ The school participates in this celebration by providing liturgical dancers and altar servers as well as the voices of the school choir. A display of religious artwork by students is also a feature of the celebration. Throughout the school year, a number of Masses are celebrated today in the school gym, with students, staff, parents and parishioners in attendance. Retired Sisters of Charity [Grey Nuns of the Cross] from the neighbouring convent also attend these school liturgies. The reception of the sacraments of the Eucharist and Confirmation by students is a highlight of spring at St. Brigid church today, as is a children's pageant on Christmas Eve. The parish and school also collaborate on holding a "Spring Fling" which sees students and their families have fun, while celebrating together as a Catholic community. Ottawa Roman Catholic District School Board. St. Brigid's School. pre-2007.

${ }^{5}$ The Shepherds have re-used numerous other buildings in Lowertown West and the Byward Market for housing and support services including Ecole Guigues before it was renovated/restored by local architect Barry Padolsky as a seniors residence.
} 


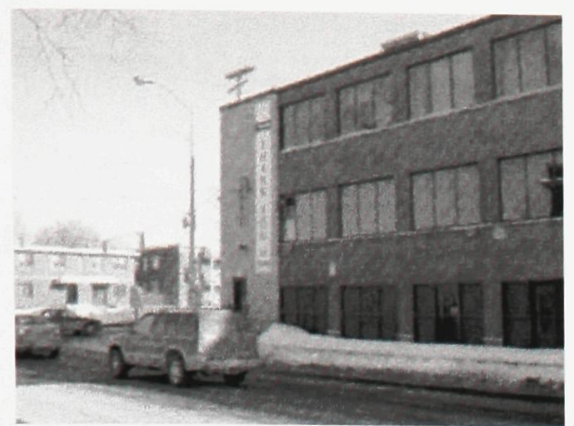

FIGURE 72: The Emergency Shelter for Shepherds of Good Hope at 265 King Edward Avenue.

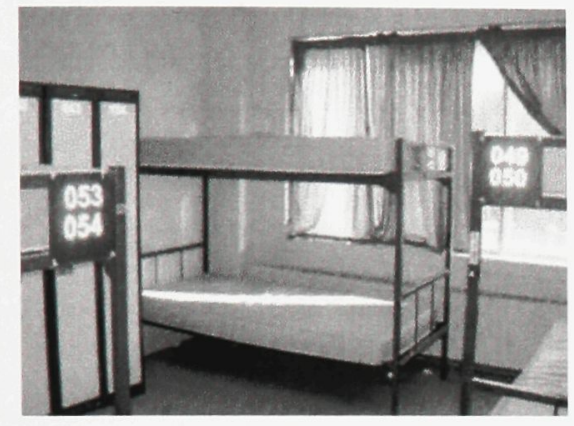

FIGURE 73: Emergency Shelter beds at 265 King Edward Avenue.

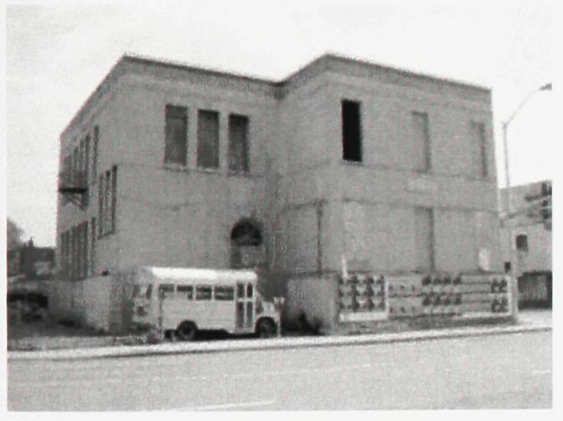

FIGURE 74: 287 Cumberland Street, proposed to be re-used as the Our Lady Community Art Centre.

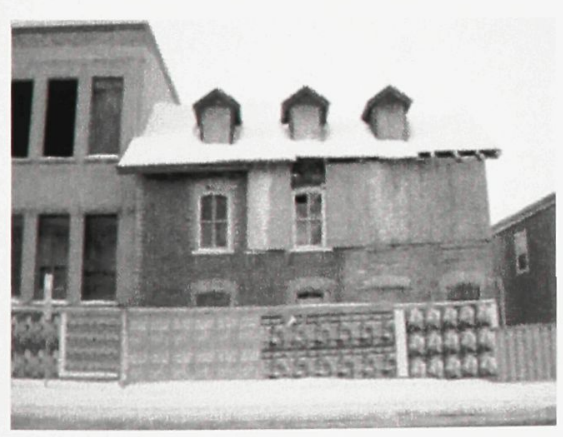

Figure 75: 207-209 Murray Street, proposed to be re-used as the library and archive for the Our Lady Community Art Centre. suffering with gentleness and compassion." ${ }^{6}$ Today, 233 Murray Street houses volunteer services, support services, a grocery and clothing program, evening drop-in, facility services and administration. An emergency shelter, divided into four distinct programs, Emergency Men's Shelter, Hope Outreach, Hope Recovery and the Managed Alcohol Program is located directly to the south of Cumberland Street at 256 King Edward Avenue. (FIgUre 72 \& 73)

The images of Saint Brigid, a patron saint of Ireland and Christ the Good Shepherd offer suggestive means of how to provide sustenance for both the body and the mind, today in a respectful manner without being overly religious. How can such meaningful images be carried forward at the site of Our Lady School? How can sustenance be provided which sustains memory, provokes intelligence and challenges foresight?

\section{PROPOSED OUR LADY COMMUNITY ART CENTRE:}

Although the work at Saint Brigid's begins to mediate the gap in "local cultural physical infrastructure ... as local artistic initiatives do not have access to the national spaces," space is still needed for local artists in the way of learning and archiving, instruction, production and display. The site of Our Lady School at 287 Cumberland and its adjacent buildings, primarily 207-209 Murray, can be re-used to fulfill this need. (FIGURE $74 \& 75$ ) In this way, the architectural project, in conjunction with its existing built heritage, appreciates the past through the storage of information and artefacts, encourages residents to engage in the telling of their own stories, allows residents to learn about their neighbours in the hopes to become more sympathetic and aware of their

\footnotetext{
${ }^{6}$ Shepherds of Good Hope. $<$ http//www.shepherdsofgoodhope.com> (January 2009) Ottawa Citizen Article.
} 


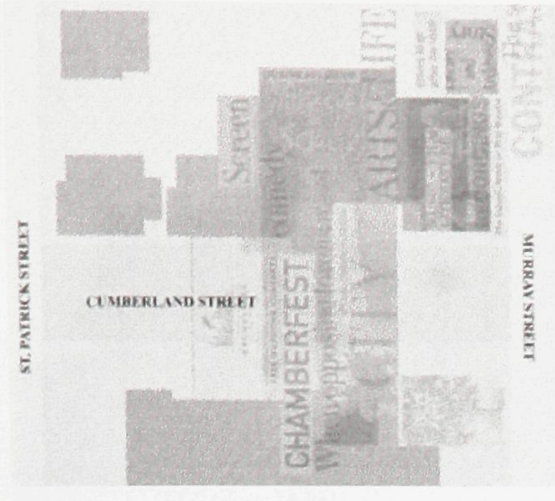

FIGURE 76: Site Collage with proposed uses for 287 Cumberland Street and 207-209 Murray Street, newspaper articles and headlines from the Ottawa Citizen 2009. Refer to Plate 3. circumstances and finally projects images of the future by creating a dialogue between the past and the present. (FIGURE 78)

It is proposed 287 Cumberland be re-used to provide specific spaces for musicians and photographers and filmmakers. Musicians can make use of a recording studio and music classroom on the second floor while photographers and filmmakers have access to a darkroom and digital studio in the basement. The ground floor is used for administration, a small showcase gallery and a multi-purpose classroom for the use of various organizations and committees requiring such a space for meetings, including the Lowertown West Community Association.

It is proposed 207-209 Murray be re-used as a library and archive for the lyrical, visual and literary arts with specific emphasis on the documentation of local artists. Poets and writers can make use of the reading rooms that surround the existing fireplaces on each of the two floors as well as the study space on the second floor.

As the arts continue to be cut from the public school system, the Our Lady Community Art Centre provides space on all three floors for after school programs. These programs emphasize how we listen, see and speak through music, photography/film and poetry/literature and in fact how all endeavors are interrelated through storytelling as expressions of who we are as individuals and as a collective community.

It is hoped the art centre will welcome a diverse array of individuals interested in learning about the arts and then sharing their knowledge and talents with others. 


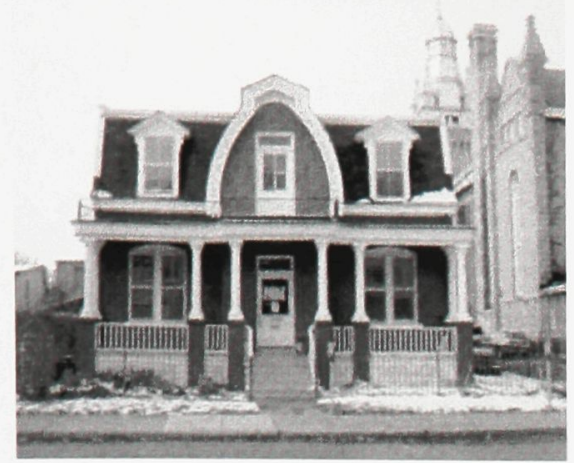

Figure 77: Operation Come Home Cactus Youth Centre located at 179 Murray Street. The home is the former church rectory for St. Brigid's Roman Catholic Church.

\section{The Lost And The Found}

Located immediately west of Saint Brigid's Centre is the current home of Operation Come Home $(\mathrm{OCH})$ at 179 Murray, a site for runaway teens and young adults. What one does not initially realize however is the home was the rectory for St. Brigid's parish. It has been suggested the convex lines of the taller tower at the Centre are echoed in the bargeboards of the gable of the rectory. (FIGURE 77)

Founded in 1971 by the late Rev. Norman Johnston, OCH is a non-profit organization dedicated to helping youth on the streets. $\mathrm{OCH}$, formerly Operation Go Home, began by helping to reunite street youth with their families - today $\mathrm{OCH}$ remains the only organization to offer this service within Canada. In 2002, to answer the needs expressed by clients at a local level, the Cactus Youth Centre was developed to administer a five pillar program: Drop-In, Education, Employment, Outreach and Reunite. Now located at 179 Murray, the drop-in centre is open from $8 \mathrm{am}$ to $1 \mathrm{pm}$ five days a week. Here eight full-time employees address the needs of 30-50 youth per day between the ages of 16 and $25^{8}$

Upon meeting with Joanne McGregor, Manager of Youth Services, in November of 2008 , it was evident to me OCH would like to be able to provide services for their youth on an even larger scale. Currently their youth have nowhere to go in the evenings; shelters in Ottawa are typically full and not the best place for youth to stay. With further funding and resources, $\mathrm{OCH}$ would like to provide emergency shelter and temporary housing for their youth.

\footnotetext{
${ }^{8}$ In 2007 , over 1000 youth contacted $\mathrm{OCH}$ for their assistance. Operation Come Home 2007 Annual Report.
} 


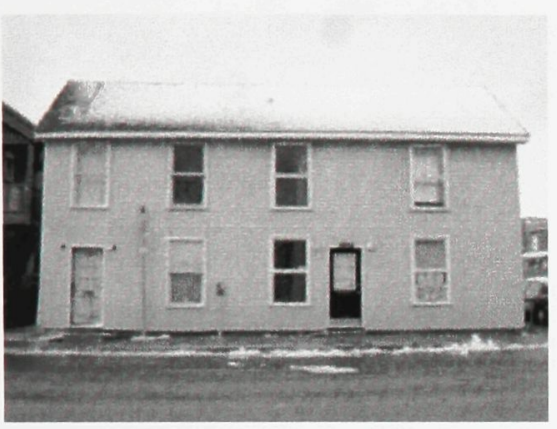

FIGURE 78: 281-83 Cumberland Street, proposed to be re-used as live/work spaces for $\mathrm{OCH}$ youth.

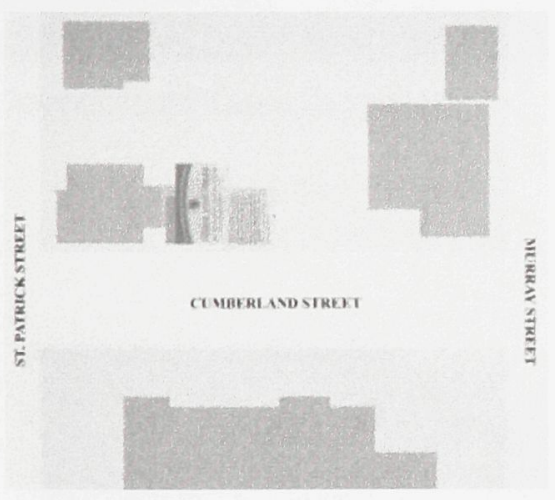

FIGURE 79: Site Collage with proposed uses for 281-83 Cumberland Street, newspaper articles and headlines from the Ottawa Citizen 2009. Refer to Plate 3.
Currently at the drop-in centre, emphasis is being placed on the employment pillar through Bottleworks and Beadworks. Both programs are administered by $\mathrm{OCH}$ youth. Beadworks has specifically involved over 60 youth in the designing and crafting of beaded jewelry now being sold at a stall in the Byward Market throughout the summer of 2009. OCH believes Beadworks allows their youth to discover new talents and realize creative work can be a positive, fulfilling and lucrative endeavor.

\section{Proposed Live/Work Spaces for OCH Youth:}

281-83 Cumberland, a former carriage house originally built between 1860 and 1870 , is proposed for re-use as live / work spaces for youth from Operation Come Home. (Figure 78) Not only will this residence provide much needed space for the youth to live, it will also provide a location for the youth to explore their interests in the arts. (FIGURE 79)

The residence provides semi-private spaces for sleeping and communal spaces for art production and learning, food preparation and cleaning. The residence itself can house up to six youth for a prescribed amount of time as established through an application process administered by $\mathrm{OCH}$.

A mentorship program established through the Our Lady Community Art Centre allows the youth to work alongside other artists. As well, employment opportunities exist for youth at the Centre in the way of maintenance, ushering and gallery fit-ups. Finally, these youth have the opportunity to participate in various programs affiliated with the Art Centre including annual art and design shows and public gardening projects on site. Through these programs, the youth can make significant contributions for the betterment of Lowertown West and can sustain their physical and spiritual 
selves in a supportive and enriching environment.

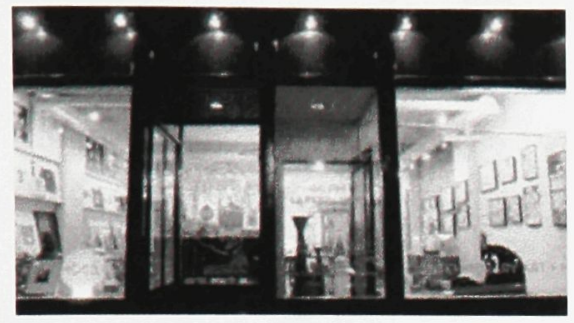

Figure 80: 306 Cumberland, La Petite Mort Gallery.

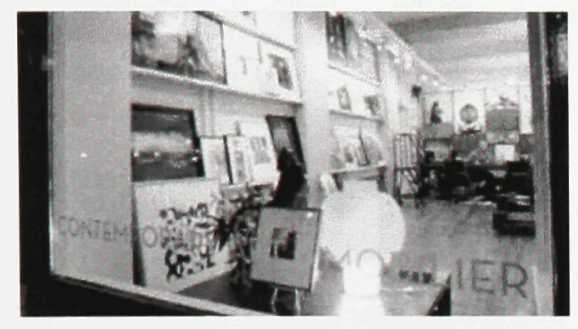

FIGURE 81: 306 Cumberland, La Petite Mort Gallery.

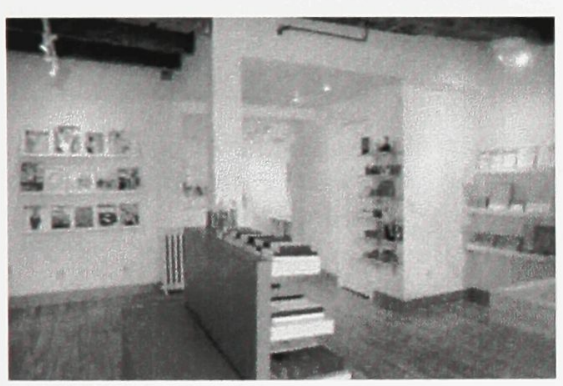

FIGURE 82: 238 Dalhousie, Canteen.

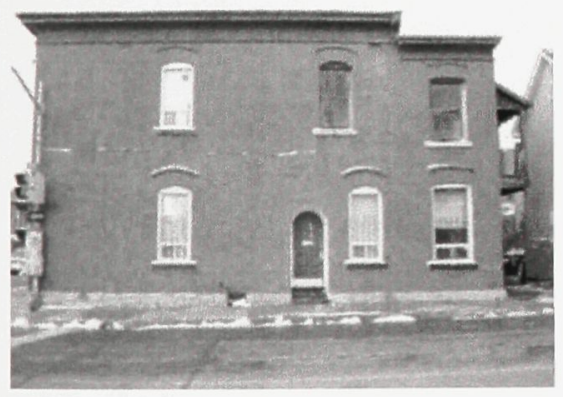

FIGURE 83: 320 St. Patrick, proposed to be re-used as studio space for interstitial artists.

\section{Musicians, Photographers and Poets}

Lowertown West is already the home of numerous artists and art galleries. Along Murray Street alone one can find over half a dozen art galleries, some more mainstream while others are site specific to Ottawa and Lowertown. Kitty corner from the site of Our Lady School, La Petite Mort Gallery at 306 Cumberland boasts "a vision of social ethics" where "the artist's struggle with self-awareness through visual art reflect[s] back to the viewer not as passive recipient but as active participant in the creative endeavour." (FIGURE 80 \& 81)

As well on Dalhousie Street shops and boutiques slightly outside mainstream culture have found their place in Lowertown. Canteen at 238 Dalhousie sells contemporary art and architecture books while offering a small gallery space for local artists to display their work. (FIGURE 82)

\section{PROPOSED STUdio SPACES FOR ARTISTS:}

Lowertown West is becoming a hub for artists in the city of Ottawa. To further foster and encourage this growth, $320 \mathrm{St}$. Patrick is proposed to be re-used as studio space for artists who are interested in working in a communal atmosphere with direct access to the facilities of the Art Centre. (FIGURE 83) Although the work of musicians, photographers, filmmakers and poets is highlighted at the Centre, this studio space is available for all artistic endeavors. Here it is intended that all artists will work with each other in a collaborative atmosphere to push boundaries and create site-specific works based on their interactions at this place. (FIGURE 84)

\footnotetext{
${ }^{9}$ La Petite Mort. $<$ http//www.lapetitemortgallery.com> (July 2009).
} 


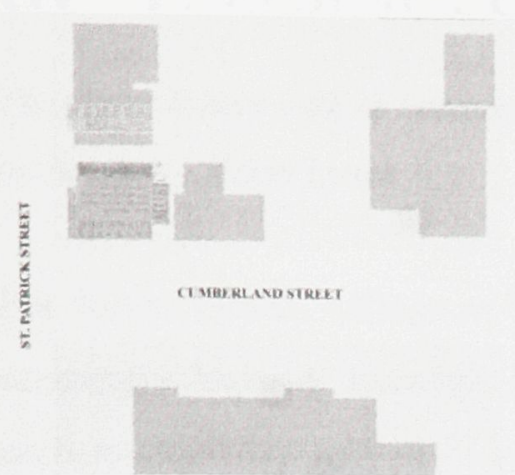

FIGURE 84: Site collage with proposed uses for 320 St. Patrick Street, newspaper articles and headlines from the Ottawa Citizen 2009. Refer to Plate 3.

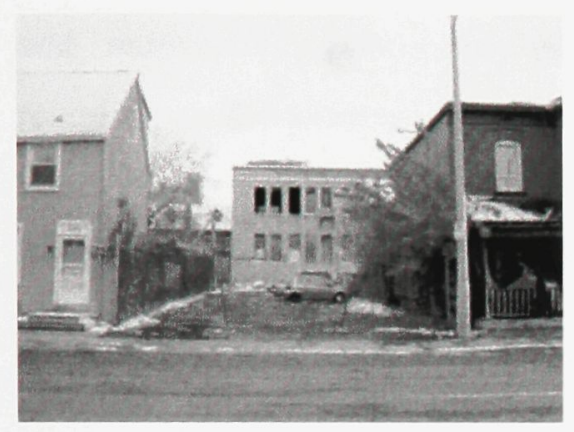

FIGURE 85: 324 St. Patrick, proposed for future construction of a gallery to display the work of interstitial artists at 320 St. Patrick.
A gallery to display the work of these artists is proposed for future construction at 324 St. Patrick, upon the existing foundations of the Minehan house. (FIgUrE 85) The Minehan house once graced this site before being purchased and demolished by the Ottawa Catholic District School Board in the 1960s to expand the schoolyard for Our Lady School.

In proposing the re-use of Our Lady, use-value is sustained and an opportunity to reconnect the community again through the supportive ethos of the Grey Nuns can be realized. How these projects are further cultivated through specific architectural interventions is explained through the use of temporal collage in the following sections. 


\section{Temporal Collage}

The future is here with us because it will be like something we knew in the past. - Kevin Lynch

For Kevin Lynch, collage is "the deliberate juxtaposition of seemingly disparate elements so that the form and meaning of each is amplified and yet a coherent whole is maintained." Lynch does not necessarily recommend elements be removed from their associated contexts, instead he suggests elements be placed in a dynamic dialogue through sensitive additive and subtractive processes, effectively the negation and reconciliation Raimund Abraham speaks of.

The term collage was originally coined to reference art which affords new meaning and new use to old / existing objects, materials and images through the process of cutting and pasting to form layers. ${ }^{2}$ Collage dates back to the Cubist images of Braque and Picasso, followed by the Dadaists and Surrealists of the early twentieth century. In each successive period, collage was almost always used as a medium to explore new ideas particular to a place and time in old objects, materials and images by removing these elements from their original physical contexts. It was not until the work of the Nouveau Realisme (New Realism) artists including Mimmo Rotella, Raymond Hains and Jacques de la Villeglé in the 1950s and 1960s in Paris, France that the use of collage began to take on a direct relationship with its site in both its physicality and its implied meaning. (FIGURE 86)

The lacerated images of the Nouveau Realisme artists were constructed through the layering of advertisements and

\footnotetext{
${ }^{1}$ Kevin Lynch, What Time is This Place? (Cambridge, MA: MIT Press, 1972), 173.

${ }^{2}$ Collage in fact comes from the French verb coller which means to glue.
}

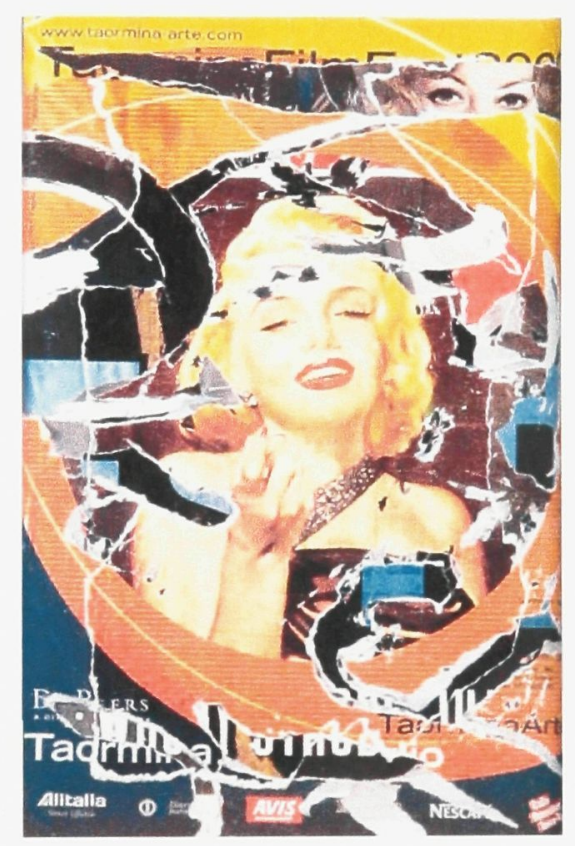

FIGURE 86: A tribute to Marilyn, Mimmo Rotella, c. 1960. 
posters in the city of Paris and then deconstructed by the artists, almost as if the images had been exposed to harsh weathering for many years. (FIGURE 87) Although the advertisements and posters had originally been collaged, or pasted together over time, the work performed by the artists themselves was a décollage, a "taking-off" of images. This "taking off" was essentially the excavation of a billboard where there was no way of knowing what existed beneath the surface of the image before the process of removal.

Today, artists continue to explore new ideas in existing objects, materials and images through both collage and décollage. A contemporary artist from South Central Los Angles, California, Mark Bradford gathers "street spam" art material including advertisements and posters to compose images that act as commentaries on the city in which he lives and works. ${ }^{3}$ Bradford's work differs from that of the Nouveau Realisme artists in that he is the author of the collage and décollage where his "street spam" is largely recycled. (and does not attempt to imply any other meaning)

With reference to his large mixed media work, including Temporary from 2005, Bradford suggests, "like those tagged up, repainted, tagged up, sanded, and repainted walls you pass everyday on the street, [his] process is both reductive and additive." (FIGURE 88) Partial layers of language and meaning are glued and taken away to uncover the comment or feeling Bradford attempts to provoke in his subject.

It is evident here the combined use of collage and décollage has allowed the lacerated images of the Nouveau Realisme

\footnotetext{
${ }^{3}$ Mark Bradford is as a painter, filmmaker and sculptor currently living and working in South Central Los Angles.

${ }^{4}$ Mark Bradford - The Whitney Press Release for the 2006 Bucksbaum Award.
}

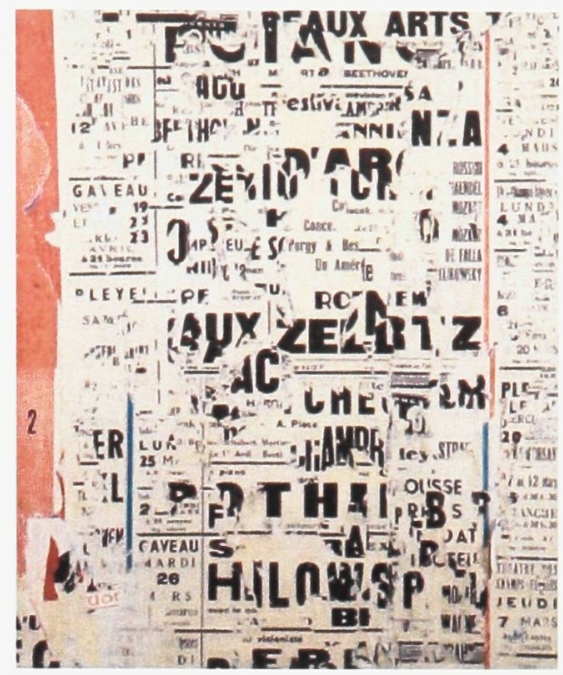

Figure 87: Les dessous du quai de la Rapée, Jacques de la Villegle, 1962.

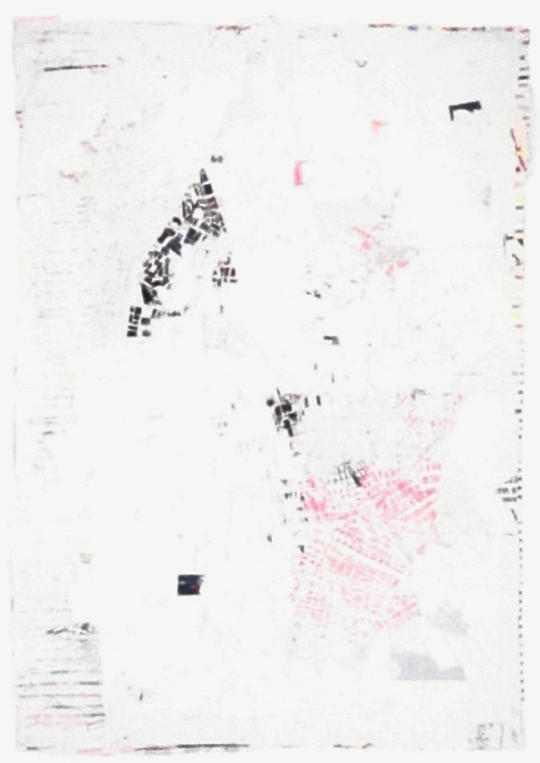

FiguRE 88: Temporary, Mark Bradford, 2005. (Note: the original image has been rotated 90 degrees clockwise) A layered image of how Bradford sees the city of Los Angles.

My practice is décollage and collage at the same time. Décollage, I take away; collage I immediately add it right back. It's almost like a rhythm. I'm a builder and a demolisher. I put up so I can tear down. I'm a speculator and a developer. In archaeological terms, I excavate and I build at the same time. - Mark Bradford 
affichistes and, similarly, Bradford's commentaries on the city of Los Angeles to be effective in exposing temporal effects and ideas with regards to specific places, spaces and time. Bradford's work especially reveals temporality in the continual process of change and evolution the work is capable of. Here the simultaneous use of collage and décollage exposes the implications of a back and forth position where importance and meaning is rendered in multiple realms and alludes to images of the literary palimpsest that provides similar visual effects.

In What Time is This Place, Kevin Lynch suggests it is through temporal collage that change is made visible in the built environment where juxtapositions can be "powerful enough to evoke the sensation that past, present and future are momentarily and mysteriously coexistent." ${ }^{, 5}$ Temporal collage, as attributed to Lynch, assumes the role of the palimpsest where the collage provides a metaphor through artistic images as opposed to literary techniques. ${ }^{6}$

Temporal collage thus recognizes value in the particular simultaneous existence of past, present and future layers at the site of the architectural project. As previously found in the Roman Palimpsest and the Margins of Berlin, the development of cities and towns layers history, meaning and use over time. This continual use and re-use through diversified needs and wants enables cities and towns to thrive and sustain themselves both culturally and socially.

\footnotetext{
${ }^{5}$ Kevin Lynch, 173.

${ }^{6}$ Since architecture can be considered to be both a language and an art, both metaphors are relevant in the description of how building and thinking can once again be connected through dwelling.
} 
To suggest an iteration for how the first layer of the collage can appropriately be modified and mediated, the second layer is applied in consultation with the present community as well as stakeholders for the project itself. For this layer architects can become more involved in the community surrounding their sites and in so doing become aware of local issues to determine the feasibility of potential new uses.

This layer henceforth carefully addresses the needs and wants of particular user groups in the community. Here the cutting and pasting of photographs, newsprint and drawings on the surface of the collage, suggests how existing conditions might be modified through creative demolition and addition to reveal and enhance meaning and use. In this way, the old and abandoned are treated more as a found objects.

With knowledge of collective memories, the episteme of techne and present use-value of the site and surroundings, the architect can take / have an informed approach when considering how the existing site should be altered. Although architects such as Rudolfo Machado often recognize "ordinary buildings that are neither monumental nor mythically loaded are rarely objects of much concern," the responsibility of architects to ensure a process of design is carried out which considers the importance of all found conditions and objects.

Knowledge of the past and present is then used to cultivate the collage to appropriately reveal and conceal necessary elements through the creation of particular architectural details. Here the collage can also begin to allocate spaces for the future and even suggest signs of it by providing spaces

${ }^{8}$ Rodolfo Machado, "Old Buildings as Palimpsest." Progressive Architecture. Nov. 1976. 
that allow for change with different uses.

\section{Temporal Use and Phased Construction}

As part of the additive process of the temporal collage, new temporary uses are encouraged within the built environment in order to generate awareness and resources in areas of anticipated rehabilitation and growth. In this way, temporal collage is always in a state of flux as an entity always changing and evolving as a process.

By assuming temporary uses in the beginning stage of a rehabilitation project, the present community is re-introduced to the area that had previously been lost. Temporary use and project phasing allow areas to grow and to be rehabilitated gradually to avoid gentrification. This gradual and systematic growth therefore encourages diversity and coexistence; "intermediate uses show us new ways of achieving urban change - alternatives to impotence, lethargy and waiting for better times."

Urban Catalyst believes temporary users are pioneers; they "discover[] the space and make[] it publicly known through their temporary use initiatives, resulting in various outcomes."10 While Urban Catalyst suggests motives to become a temporary user often differ, "all temporary users have at least one characteristic in common: they are often on a threshold, on the way into or out of mainstream society and regular activities." 11 Temporary users are therefore 'in-

\footnotetext{
${ }^{9}$ Urban Catalyst, "Patterns of the Unplanned." In Loose Space: Possibility and Diversity in Urban Life. (Abingdon, Oxon: Routledge, 2007), 282.

${ }^{10}$ Ibid, 276.

"Ibid, 277.
} 
transition' and can help to define the ethos of an area.

In this temporary use however Kevin Lynch believes "...there must be some sense of completeness at every stage of development so that each generation has some visually stable surroundings, some feeling of living in today rather than tomorrow." 12 As any rehabilitation project begins to take shape through temporary use, phased development and construction, users need to have the sense that they are living in a present condition that continues to provide new opportunities. Otherwise, each generation attempts to anticipate the future while rejecting the importance of the present moment. Effectively here a step back is being made by re-suggesting it is the future that holds a utopia which is ultimately unattainable. Lynch believes henceforth,

the best environment for human growth is one in which there are both new stimuli and familiar reassurances, the chance to explore and the ability to return. ${ }^{13}$

Phased construction can allow for this growth and reassurance by determining goals for the immediate as well as distant future while continuing to suggest architecture is a process that needs to be challenged and adapted to remain viable and provide sustenance.

\section{Architecture as Process: IN THE WORK OF MS \& R ARCHITECTS}

It is hard to anticipate the outcome of a collage or décollage at the outset of the design process. The designer may have an image in mind of what will be cultivated but ultimately the resultant image cannot be predicted; there is no finite outcome. The temporal collage is never finished, layers of history, meaning and use can continue to build up and to anticipate areas of future growth while others

\footnotetext{
${ }^{12}$ Kevin Lynch, 198.

${ }^{13}$ Ibid, 204.
} 
can be suppressed. Accordingly Kevin Lynch believes, "the model of perpetual revolution locates its values in the process itself - not in the results, but in the states of mind or patterns of social relations that accompany the process."14

Meyer Scherer and Rockcastle Architects (MS \& R) rely on this process of layering through time to encourage old buildings to be used in new ways particular to their place and according to their users. The site of Open Book, a cultural centre for reading, writing and book arts in Minneapolis, Minnesota, renovated by the firm in 2000, reveals qualities of a temporal collage. (FIgure 89, 90 \& 91) Through both additive and subtractive elements MS\&R remain sensitive to the existing conditions of the three existing buildings they renovate while allocating space for interstitial endeavours through unique architectural details at the junctures between new and existing.

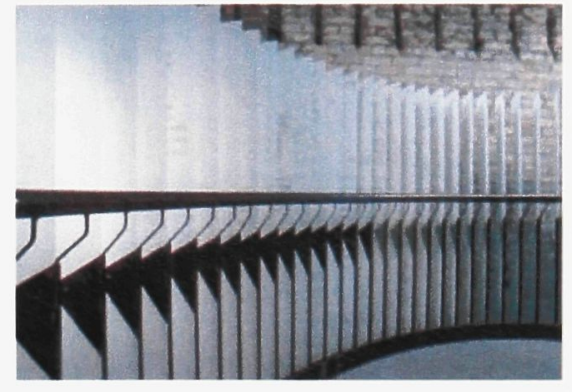

FIGURE 89: Central Staircase, Open Book, Minneapolis, MN, MS\&R Architects.

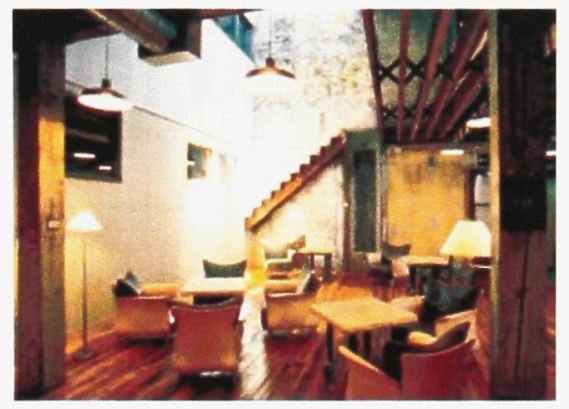

Figure 90: Open Book, Minneapolis, MN, MS\&R Architects.

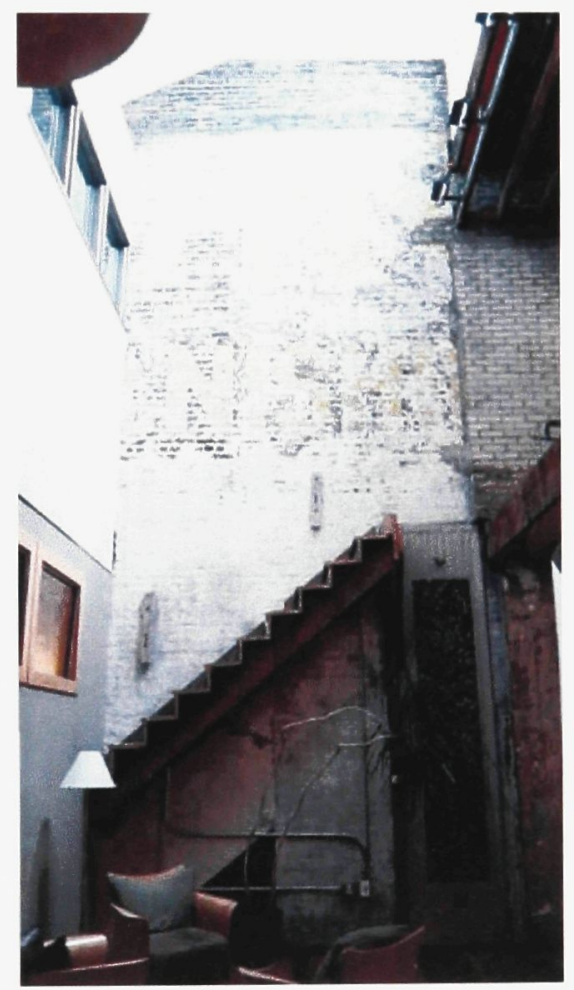

Figure 91: Open Book, Minneapolis, MN, MS\&R Architects.

\footnotetext{
${ }^{14}$ Kevin Lynch, 212.
} 


\section{To Cultivate The InTerstice}

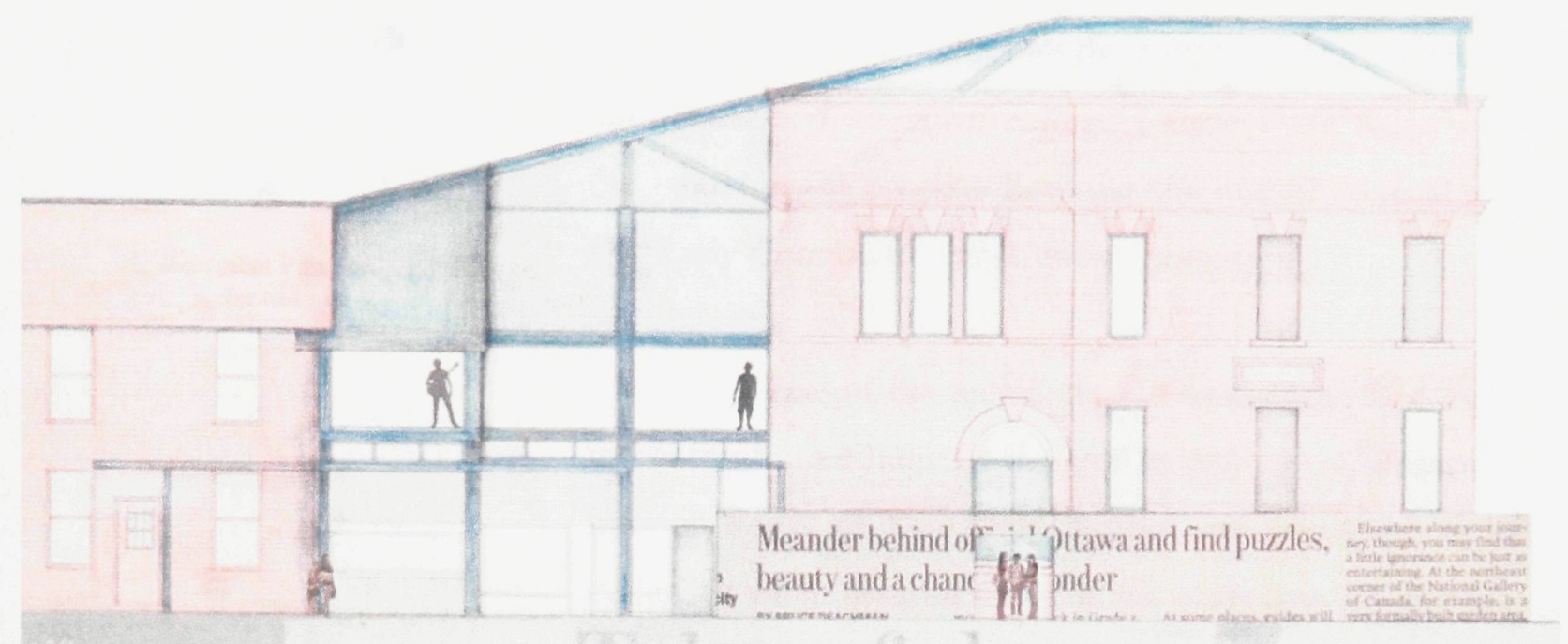

FIGURE 92: West Elevation of Our Lady Community Art Centre, Live / Work Residence for OCH Youth and Artist Studios, originally drawn at 1:100 scale. Refer to Plate 4.

While we often suggest architecture is or has been "generated" through a specific process we impose, here I propose architecture is cultivated, as I have found it to be through the use of temporal collage. "To cultivate," in this sense, is to promote or improve the growth of, to develop or improve by education or training while "to generate" is to bring into existence or production. Here generating is suggestive of an end and not the means which cultivating supposes.

Further, to cultivate the interstice is to promote and improve the growth of the in-between space, effectively sites 'intransition.' I have already come to recognize the site of Our Lady to be interstitial yet its current position is not being used in a positive and enriching way. Here I suggest the means by which the interstitial qualities of the site can be cultivated through the implementation of a phased architectural project that gives emphasis to the particularity of the in-between in architectural joints and connections. 


\section{The Architectural Interstice}

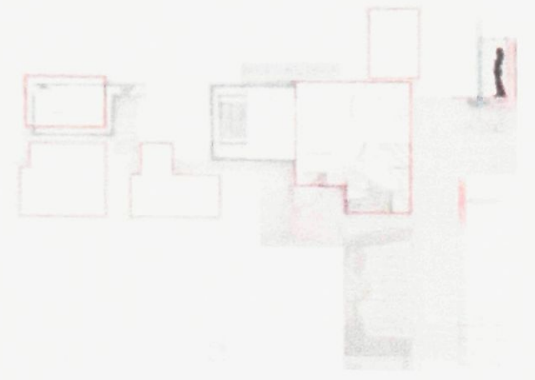

FIGURE 93: Basement Plan, originally drawn at 1:100 scale. Refer to Plate 5 .

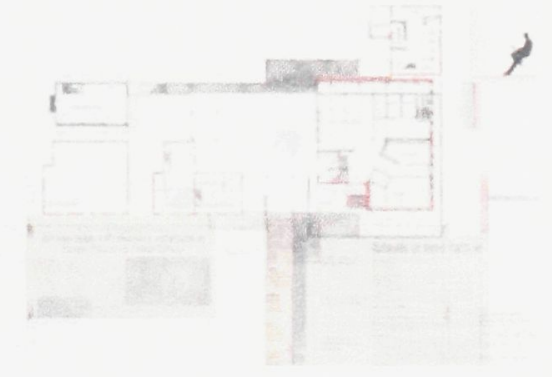

FIGURE 94: Ground Floor Plan, originally drawn at 1:100 scale. Refer to Plate 6.

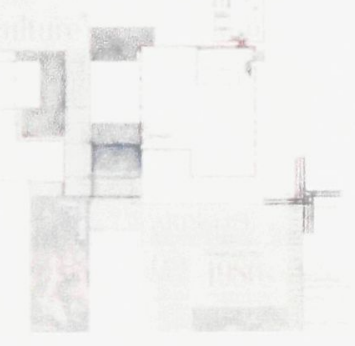

FIGURE 95: Interstice Floor Plan emphasizing the imagery of the Saint Brigid Cross, originally drawn at $1: 100$ scale. Refer to Plate 7.

Figure 96: Second Floor Plan, originally drawn at 1:100 scale. Refer to Plate 8 .

Refer to Plates ... for images of site model, $1: 100$ in scale.
The interstitial nature of the site of Our Lady has been revealed to me in its memory and history, as well as its use and potential re-use. Through the representative means of the palimpsest and temporal collage I further use the image of the interstice, to propose how the site can be re-used as the Our Lady Community Art Centre. (Figure 93-96)

The first layers of the architectural representations document the current conditions of the site in red. Also, because the interior floors of Our Lady School are presumed to have collapsed when the roof caved in ten years ago, interior walls, doors and stairs are drawn lightly in red to denote their former presence. By highlighting these existing conditions I have been encouraged to recognize their present or former existence.

These first layers are then suggestive of how to place those that follow. In some instance I have placed new interventions directly on top of those existing to create a sense of continuity through a new material while in others I juxtapose elements to heighten a change in use. In nearly all instances however, the connection points between existing and new conditions, drawn in blue, acknowledge an intersection and encourage users to become conscious of these transitioning spaces and elements.

While these transitory moments are most notable between existing and new architectural elements, their presence is also evident at the intersection between new spaces and materials. The following spaces and details have been cultivated specifically at the site for the Art Centre according to existing and former conditions and are suggestive of both continuity and juxtaposition. These details have been drawn in the 


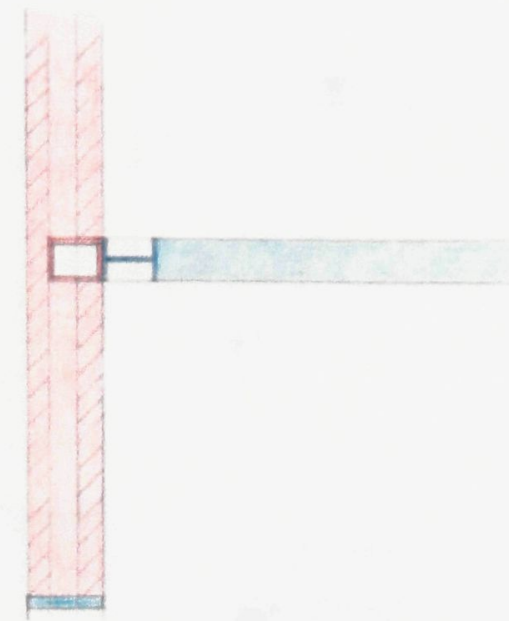

FIGURE 97: Detail of connection between existing cast-iron columns and new steel ibeams.

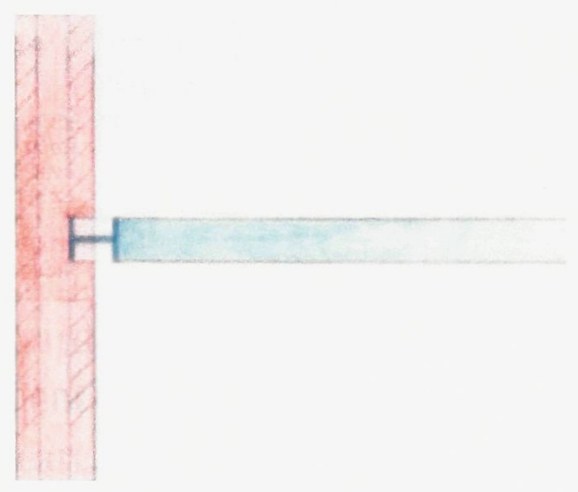

FIGURE 98: Detail of connection between existing masonry shell and new interior walls.

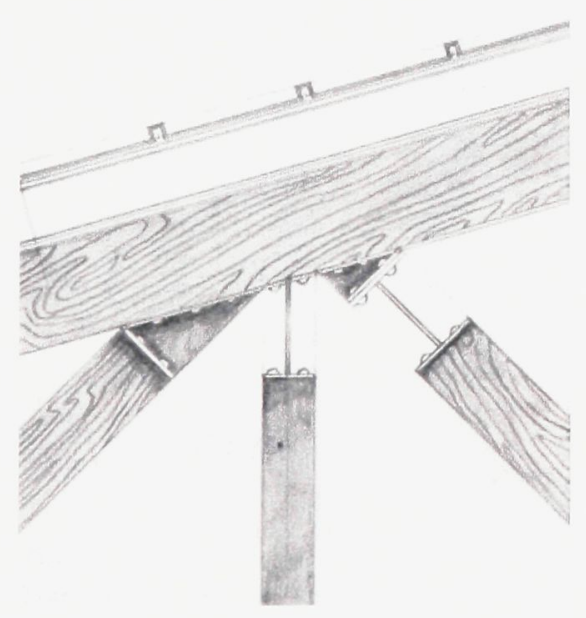

FIGURE 99: Detail of connection between new wood rafters and new wood trusses. margins of the drawings themselves and become further integrated with the plans and sections through a collage of Ottawa Citizen newspaper articles which denote both existing and potential conditions.

\section{The STRUCTURE AND THE ROOF}

The structure of Our Lady is composed of cast-iron columns embedded within its masonry shell while the east wall is load-bearing masonry. Attention is given to the location of the existing cast-iron columns to propose the placement of new steel columns and beams. To structurally stabilize the existing shell, these new columns and beams are similarly placed at their existing and former locations within the school building. (FIGURE 97 \& 98)

Outside of the school building however, the structural grid that is used acknowledges the east / west placement of columns within the school while the north / south distance between columns is determined by the use of materials and size of the main meeting and performance space for the Art Centre. These new columns are steel I-beams encased in concrete to support the concrete floors of the bridges above and the new roof.

In order to offer a sense of continuity between the school and this adjacent meeting space, to provide a high ceiling for the music classroom and to accentuate the presence of the rehabilitation project at the street level, a new roof replaces the existing of the school building and is connected to that of the main performance and meeting space. Wood supports with metal connectors extend from the steel and concrete columns to give the appearance the roof is resting lightly on its supports. (FIGURE 99) 


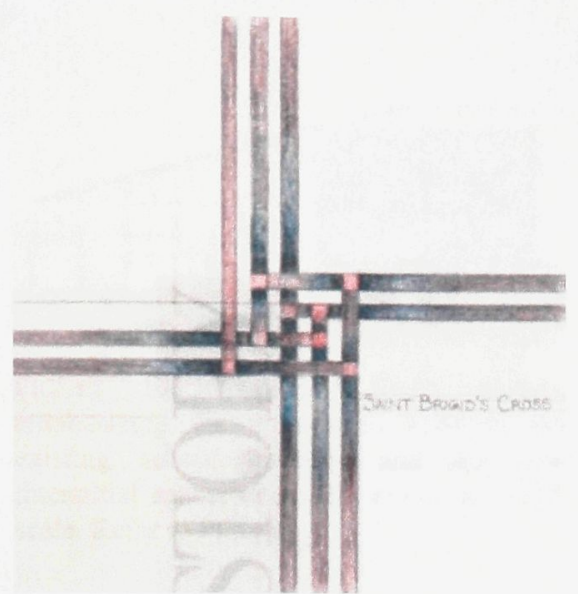

FIGURE 100: Cross of Saint Brigid

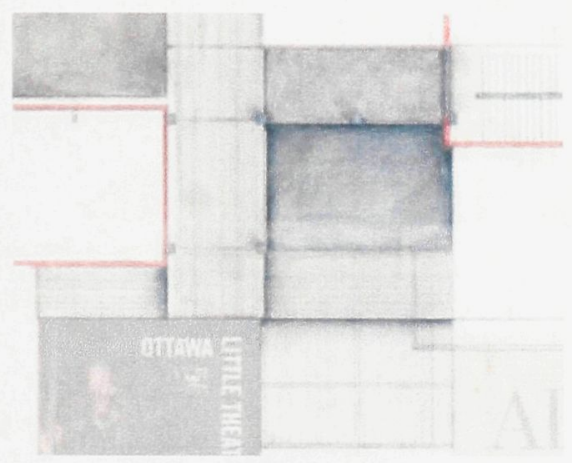

FIGURE 101: Cross of Saint Brigid in Plan.

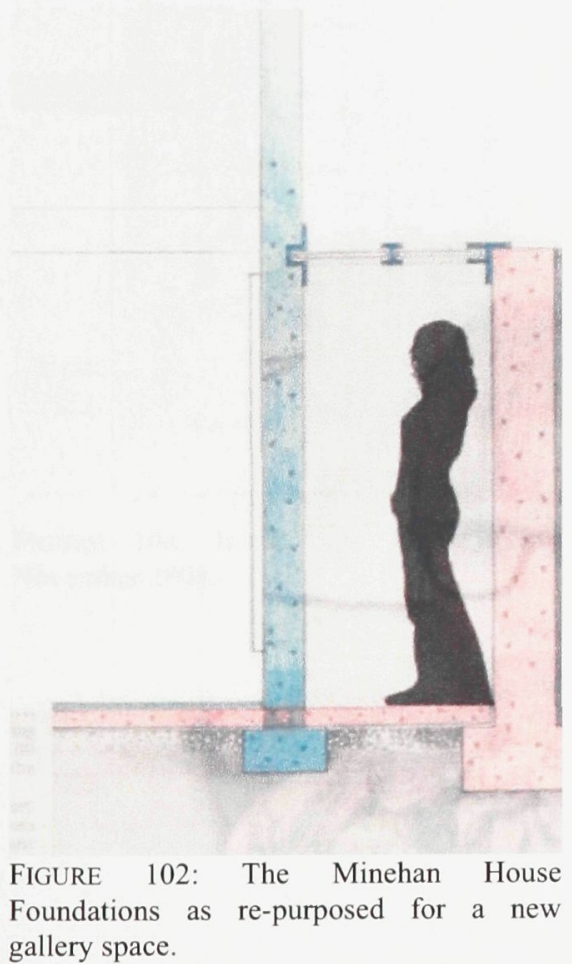

\section{The Cross of SAInt BRIGID}

The cross of Saint Brigid, as found at the main entrance space to the Art Centre, is a three-dimensional representation of the cross traditionally made to honour one of the patron saints of Ireland on her feast day. St. Brigid crosses are traditionally made of rushes or straw and it is believed their presence protects houses from fire and from evil. (FIGURE 100)

The re-appropriated use of the cross of Saint Brigid offers the means to propose architectural elements that work in continuity and juxtaposition with each other. The lines of the cross are seen in the overlapping layers of the plans and elevation of the main entrance space. Specific delineations in the floors and ceilings help to reveal this image. (FIGURE 101)

Spatially, this is the main joint or knot within the architectural project as it connects 281-83 Cumberland, Our Lady and the new performance / meeting space together.

\section{The Minehan House Foundations}

At the site of 324 St. Patrick, it has been suggested the foundations still exist of the former Minehan house. As part of a later phase for the architectural project I propose, I consider excavating this site to locate these foundations and recognize their presence as an architectural artefact. The casting of new foundations creates an identical volume to the existing yet is juxtaposed to the original.

Used as a gallery space for the interstitial artists at 320 St. Patrick, this juxtaposition creates light wells between the new and existing foundations. The walls of the volumes bound the gallery space itself where they intersect. (FIGURE 102) 


\section{The Stage / Backstage}

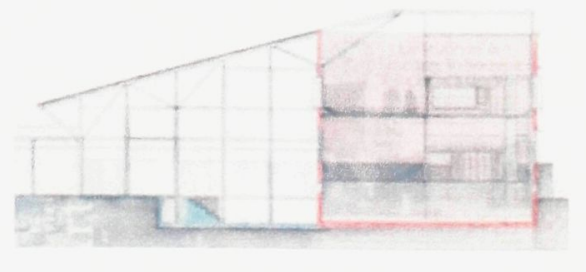

FIGURE 103: North / South Section emphasizing the connection between the existing school building and the new interstitial space, originally drawn at 1:100 scale. Refer to Plate 9.

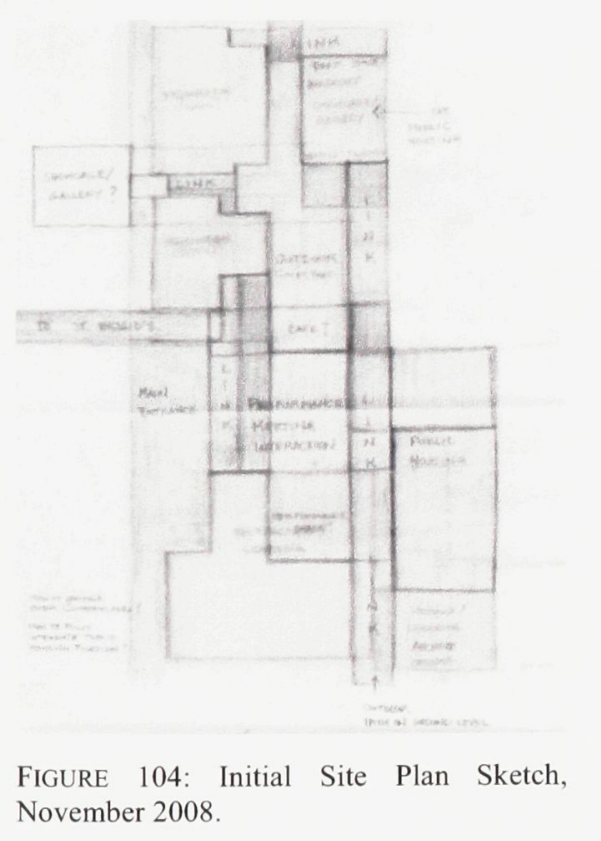

The north wall of the existing school building acts as a backdrop for events held at the Our Lady Community Art Centre including lectures, theatre performances and concerts. Instead of turning away from the school building, the audience sits directly facing the existing wall to acknowledge its presence and value. The wall itself is the mediator between the interiors of the classrooms and the new meeting space on the ground and second floors. At the basement level, the wall is the dividing point between the backstage within the school structure and the main stage in the new interstitial space. (FIGURE 103)

\section{The ArChitect}

As the architect of this story, I hope I have been able to bring light to this misunderstood site. It is a site of immense potential which can only be realized if one is able to see the site as a temporal collage - ever changing but always leaving traces of a previous time to be commented on. (FIGURE 104)

In the proposal I make I use the theory I have read and researched along with my site documentation and interactions with the present community to cultivate, in every sense of the word, a specific way of working that focuses on a process instead of an end product. In this way it is proposed the architectural project, even for the extent of the design I offer, can occur as a phased construction over time.

The first step of this phased work proposes to re-use the four existing buildings according to the delineation of space and function suggested in the previous chapter. At this time, bridges are also constructed to connect these four buildings 
with each other to begin to offer a sense of continuity and community.

The second step of this work involves the construction of the central meeting space for the Art Centre including a stage and seating for various events and performances, a space for the purchasing and pickup of tickets for both the Art Centre and Saint Brigid's and a new main entrance which physically and metaphorically extends towards Saint Brigid's. At this time it is suggested Cumberland Street between St. Patrick Street and Murray Street cease to function as such and be repurposed to physically join the space between Saint Brigid's and Our Lady. This physical connection will allow and encourage pedestrian traffic as well as provide space for outdoor concerts and events.

Finally, the last step of the interventions I propose excavates at the site of 324 St. Patrick to reveal the foundations of the Minehan house and provide gallery space for the interstitial artists at 320 St. Patrick to display their work. Also at this time, it is proposed a café be added in the rear yard of 207209 Murray to be used especially in connection with the library and archive.

\section{And The Community}

Through this phased construction interest and funds can be garnered for further efforts and work within the community. Throughout the duration of this thesis, I have already seen first hand the interest that has been cultivated at the site of Saint Brigid's. Here, it is proposed the project for Our Lady work in conjunction with current efforts at Saint Brigid's to involve the larger Lowertown West and Byward Market communities. 


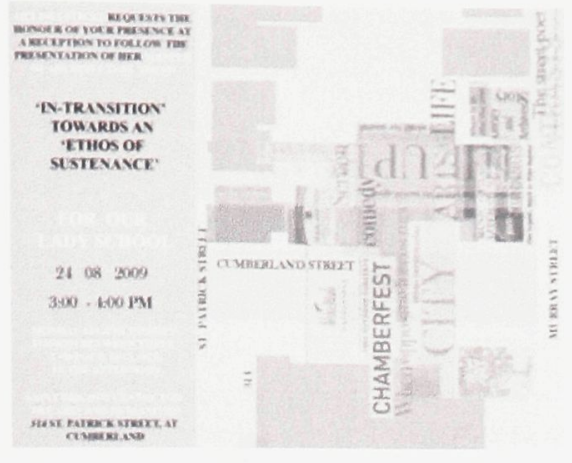

FIGURE 105: Invitation for the reception to follow the defense of this thesis on August 24, 2009 between 3:00 and 4:00 PM. Refer to Plate 16.

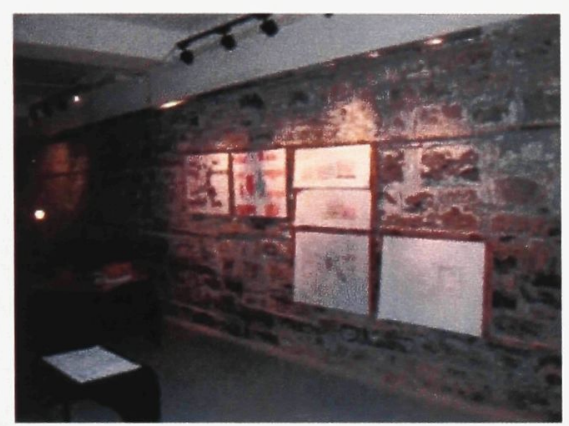

FIGURE 106: Thesis defense at Saint Brigid's, August 24, 2009.

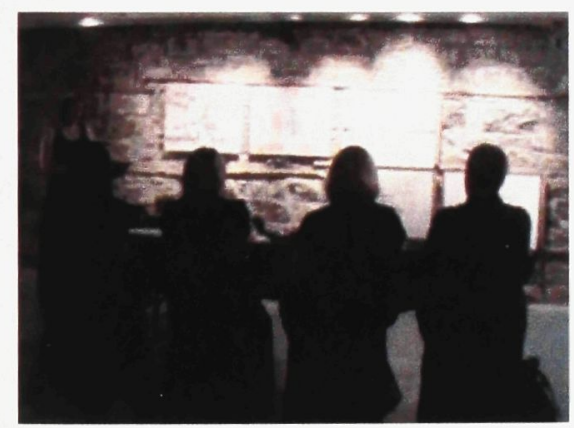

FIGURE 107: Thesis defense at Saint Brigid's, August 24, 2009. (Professor Federica Goffi, Dr. Claudine Déom, Professor Sheryl Boyle, Dr. Stephen Fai)
It is hoped by presenting this thesis at the site of Saint Brigid's, further interest will be cultivated for the site of Our Lady in the Lowertown West community and a dialogue between residents will acknowledge the immense potential and possibilities for the site. (Figure 105, $106 \& 107$ ) 


\section{EPILOGUE}

An environment that facilitates recalling and learning is a way of linking the living moment to a wide span of time. Being alive is being awake in the present, secure in our ability to continue but alert to the new things that come streaming by. We feel our own rhythm, and feel also that it is part of the rhythm of the world. It is when local time, local place, and our own selves are secure that we are ready to face challenge, complexity, vast space, and the enormous future. - Kevin Lynch

This thesis has shown that dwelling resides in the space between building and thinking - the practice and theory of architecture and that this relationship is possible by simultaneously acknowledging the presence of the past, the present and the future. This consciousness is revealed in the making of architecture where the joint, as the point of intersection, reveals particular elements of an architectural palimpsest.

\section{The Return of Prudence}

Conscious in the present moment ('in-transition'), the invisible third face of Janus and the Allegory of Prudence is revealed in the architecture of a specific place and time. It has been suggested by Marco Frascari that the architecture of this image is a monstrous one but the image is a monster that is both real and imaginary, physical and metaphysical. ${ }^{1}$ With this recognition comes sustenance for the mind where the cultivation of a site is revealed in the joint, the detail which in itself is conscious of what has come before and what will

\footnotetext{
${ }^{1}$ Monstrous architecture and architectural monsters stand at the margin of consciousness between the known and the unknown, the perceived and the unperceived, calling into question the adequacy of our ways of organizing rationally the world into determinable parts and details. Marco Frascari. Monsters of Architecture: Anthropomorphism in Architectural Theory. Rowman \& Littlefield Publishers, Inc.: Savage, Maryland, 1991, 34
} 
come after. Frascari believes,

The edges of walls, the capitals, the keystones, and all the possible architectural elements that express the nature of constructional joints are the places that articulate these monstrous events. These events/joints are architectural monsters that make people think about their environment. ${ }^{2}$

Frascari suggests it is the details of an architectural project, as they refer to an existing presence (text) and a potential further use, that allow it to be nontrivial and thus site-specific. It is the detail, the joint and its relationship to the bigger architectural project, that allows the layering of stories to enhance memory, meaning and use as opposed to subtracting from it.

Further, the image of the monstrous body is one that is sustained through time by always appreciating the present moment in relation to the past and future. In this way the present is itself active as the moment of inter-action, too often disregarded to preserve the image of the past or remain fixed on an image of the future. The monstrous body therefore is always in a state of "becoming" says Frascari where the body is "never finished, never completed; it is continually built, continually created; and it is the principle of others' bodies."

The detail therefore is the site of architecture 'in-transition' that helps to reveal the character and ethos of a city, town, community or group. It is how we use and interact with these sites in-transition that reveal our ethos. To further rely on this metaphor, it is this point of intersection that has the opportunity to reveal what it means to dwell genuinely and can declare the once lost 'ethos of sustenance' to be found.

\footnotetext{
${ }^{2}$ Ibid, 16 .

${ }^{3}$ Ibid, 32 .
} 


\section{THE FOUND ETHOS}

This thesis has further shown the necessary qualities for the creation of architectural monsters and thus a specific approach to the tricephaleous image of building, dwelling and thinking. The means of the approach are not foreign to us but for whatever reason - cultural, social, economic, environmental, political - they are concealed, not always encouraged or pursued. It is no longer appropriate to rely completely on standards and guidelines for architectural projects. Models and precedents may be referenced, but each site can move forward according to its own rhythm, as defined through its particularity. Respect needs to be given to past and present conditions that allow us to see new possibilities in the future from previous and current successes as well as failures.

The lost 'ethos of sustenance' can be found because it exists in what we already know. Presently hiding, waiting to be uncovered and revealed, to find this ethos is to reveal the importance of particularity in language and meaning within the built environment.

An 'ethos of sustenance' therefore makes a genuine dwelling possible as it supports new and sustains existing cultural and social initiatives through architectural endeavours. An ethos which sustains, nourishes and supports through architecture 'in-transition' by listening, seeing and responding extends beyond all preconceptions to reveal potential and value in particularity. It is only through this consciousness in the present moment that the architectural monster can be seen as a body to be cherished instead of a body to be feared. 


\section{BIBLIOGRAPHY}

Abraham, Raimund. "Negation and Reconciliation.” Perspecta. Vol. 19. 1982, pp.6-13.

Aristotle. The Nicomachean Ethics. Translated by. J. A. K. Thomson. London, England: Penguin Books, 1953.

Bedard, Jean-Francois, Mildred Friedman, Alba Di Lieto, Nicholas Olsberg, Sergio Polano, and George Ranalli. Carlo Scarpa Architect: Intervening with History. Montreal, QC: Canadian Centre for Architecture and The Monacelli Press, 1999.

Benjamin, Walter. "The Work of Art in the Age of Mechanical Reproduction," Illuminations, trans. Harry Zohn. New York: Schocken, 1978.

Boyer, Christine M. The City of Collective Memory. Cambridge, MA: The MIT Press, 1994.

Brandenburg, Hugo. Ancient Churches of Rome from the Fourth to the Seventh Century. Turnhout, Belgium: Brepolis Publishers N.V., 2004.

CBC News. Turn Abandoned Buildings into Affordable Housing: Activists. October 29, 2007.

City of Ottawa. Our Heritage: Report of the Mayor's Committee on the Heritage. November 1972.

Cupers, Kenny and Markus Miessen. Spaces of Uncertainty. Verlag Muller + Busmann: Wuppertal, Germany, 2002.

Dillon, Sarah. The Palimpsest: Literature, Criticism, Theory. New York, NY: Continuum, 2007.

Foster, Carter E. Neither New Nor Correct: New Work by Mark Bradford. New York, NY: Whitney Museum of American Art, 2007.

Frascari, Marco. Monsters of Architecture: Anthropomorphism in Architectural Theory. Savage, Maryland: Rowman \& Littlefield Publishers, 1991.

Frampton, Kenneth. "Rappel a 1'Ordre: The Case for the Tectonic." In Constancy and Change in Architecture. College Station: Texas A\&M University Press, 1991.

Greber, Jacques. Plan for the National Capital: General Report. Ottawa, ON: National Capital Planning Service, 1950.

Halbwachs, Maurice. The Collective Memory. New York, NY: Harper \& Row, Publishers, Inc., 1980.

Harries, Karsten. "Space, Place, and Ethos: Reflection on the Ethical Function of Architecture." Artibus et Historiae. Vol. 5. No. 9. 1984. pp.159-163.

Harries, Karsten. "Time, Death, and Building." In Constancy and Change in Architecture. College Station: Texas A\&M University Press, 1991. 
Harries, Karsten. “The Ethical Function of Architecture.” Journal of Architectural Education. Vol. 29. No. 1. Humanist Issues in Architecture. September 1975, pp.14-15.

Harries, Karsten. The Ethical Function of Architecture. Cambridge, MA: MIT Press, 1997.

Heidegger, Martin. “ Building Dwelling Thinking.” In Poetry, Language, Thought. Translated by Albert Hofstadter, New York, NY: Harper \& Row Publishers, 1971

Heritage Canada Foundation. Federal Financial Tax Incentives for Heritage Places (SOC08.3.07). February 122008

$<$ http://www.heritagecanada.org/eng/services/advocacy.html $>$.

Heroux, Denis. Proposed Conversion - Our Lady's School - 287 Cumberland Street. Thesis Work for the Department of Architecture at Algonquin College ed. Ottawa, Ontario: 1984.

Hollier, Denis and Liesl Ollman. "The Use-Value of the Impossible.” October. Vol. 60. Spring 1992, pp.324.

Huyssen, Andreas, Present Pasts: Urban Palimpsests and the Politics of Memory. Stanford, CA: Stanford University Press, 2003.

ICOMOS. The Venice Charter. $1964<\mathrm{http}$ ://www.international.icomos.org/charters/venice_e.htm>.

ICOMOS. The Washington Charter. $1987<\mathrm{http}$ :/www.international.icomos.org/charters/towns_e.htm>.

Jackson, H. J. Marginalia: Readers Writing in Books. New Haven, CT: Yale University Press, 2001.

Jacobs, Jane. The Death and Life of Great American Cities. New York, NY: Random House Inc., 1961.

Kessler, Mark. "Sowing Seeds of Diversity: The Influence of Sustainability on Adaptive Reuse." The Value of Design: design is at the core of what we teach and practice. Washington, D.C.: ACSA Press, 2009, pp.510 $-517$.

Leatherbarrow, David and Mohsen Mostafavi. On Weathering: The Life of Buildings in Time. Cambridge, MA: The MIT Press, 1993.

Le Corbusier. The Radiant City. New York, NY: The Orion Press, 1933.

Le Corbusier. Towards a New Architecture. London, England: The Architectural Press, 1923.

Lynch, Kevin. What Time is This Place? Cambridge, MA: The MIT Press, 1972.

Marx, Karl. Capital: A Critique of Political Economy. Edited by Frederick Engels, Translated by Samuel Moore and Edward Aveling, Revised by Ernest Untermann, New York, NY: Random House Inc., 1906, pp. $42-48$.

McClelland, Michael. "Lowertown West Heritage Conservation District Study.” May 1993.

McLeod, Mary. "Architecture and Politics in the Reagan Era: From Postmodernism to Deconstructivism." Assemblage. No. 8. Feb. 1989, pp. 22-59. 
Machado, Rodolfo. “Old Buildings as Palimpsest.” Progressive Architecture. Nov. 1976.

Murphy, Richard. Carlo Scarpa and Castelvecchio. Butterworth Architecture: London, England, 1990.

Norberg-Schulz, Christian. Architecture: Presence, Language, Place. Milano, Italy: Skira, 2000.

Panofsky, Erwin. “Titian's Allegory of Prudence." In Meaning in the Visual Arts. Chicago, IL: The University of Chicago Press, 1955.

Perez-Gomez, Alberto. “Architecture as Embodied Knowledge." Journal of Architectural Education. Vol. 40. No. 2. Jubilee Issue. Winter 1987, pp.57-58.

Perez-Gomez, Alberto. "The Modern City: Context, Site, or Place for Architecture." In Constancy and Change in Architecture. College Station: Texas A\&M University Press, 1991.

Planning Branch, Department of Planning and Works. Urban Renewal: Ottawa, Canada. Corporation of the City of Ottawa: Ottawa, Ontario, 1967.

Powell, Kenneth. Architecture Reborn: Converting Old Buildings For New Uses. New York, NY: Calmann \& King Ltd., 1999.

Reynolds, Nedra. "Ethos as Location: New Sites for Understanding Discursive Authority." Rhetoric Review, Vol. 11. No. 2 Spring, 1993, pp.325-338.

Riegl, Alois. "The Modern Cult of Monuments: Its Character and Its Origin.” In Oppositions Reader. New York, NY: Princeton Architectural Press, 1998, 621-651.

Smith, Julian. "Byward Market Heritage Conservation District Study.” September 1990.

Till, Jeremy and Sarah Wigglesworth. "Strong Margins." Architectural Regionalism: Collected Writings on Place, Identity, Modernity, and Tradition. New York, NY: Princeton Architectural Press, 2007.

Urban Catalyst. "Patterns of the Unplanned." Loose Space: Possibility and Diversity in Urban Life. Abingdon, Oxon: Routledge, 2007.

Wright, Frank Lloyd. The Living City. New York, NY: Horizon Press, 1958. 


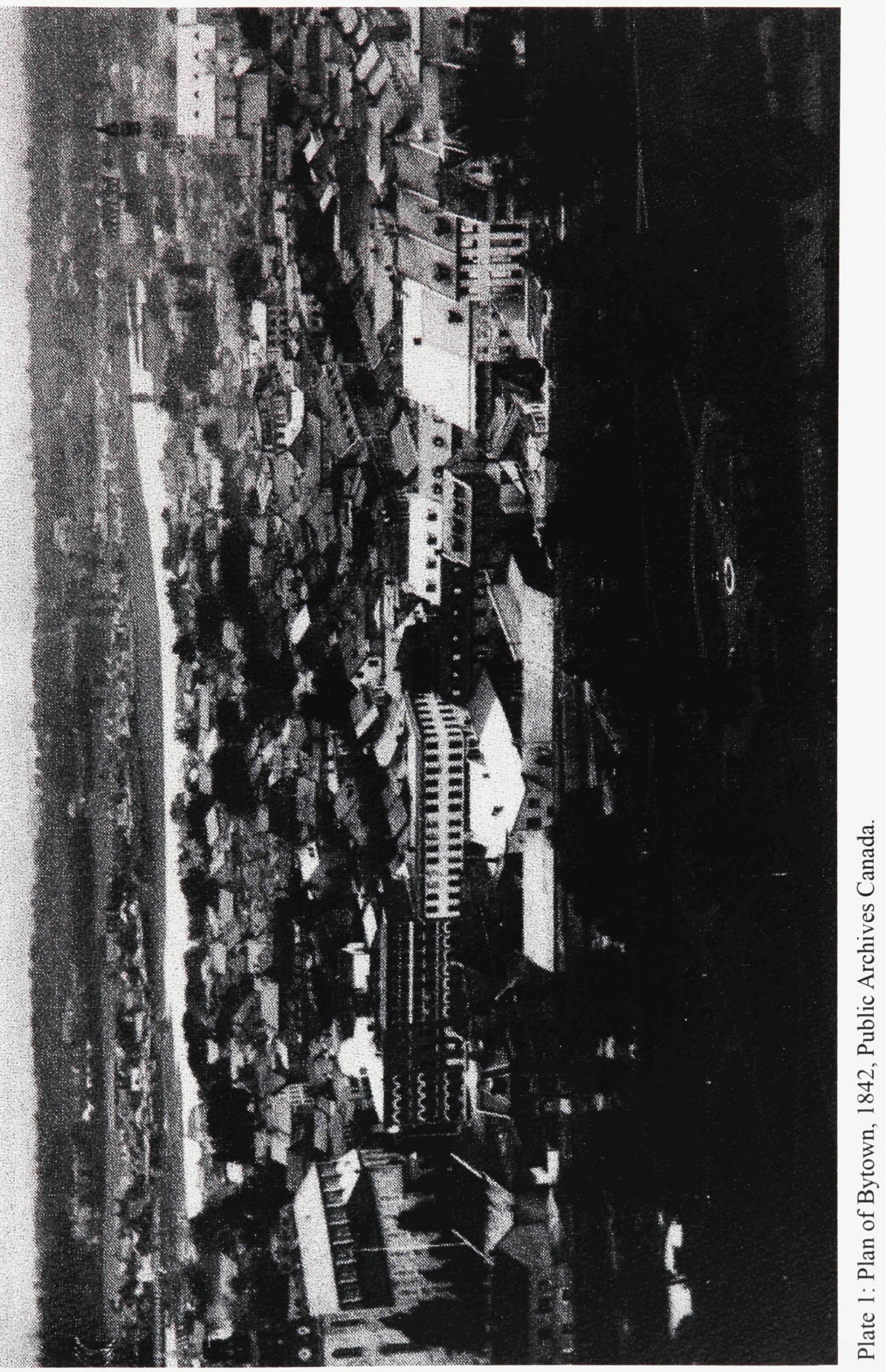




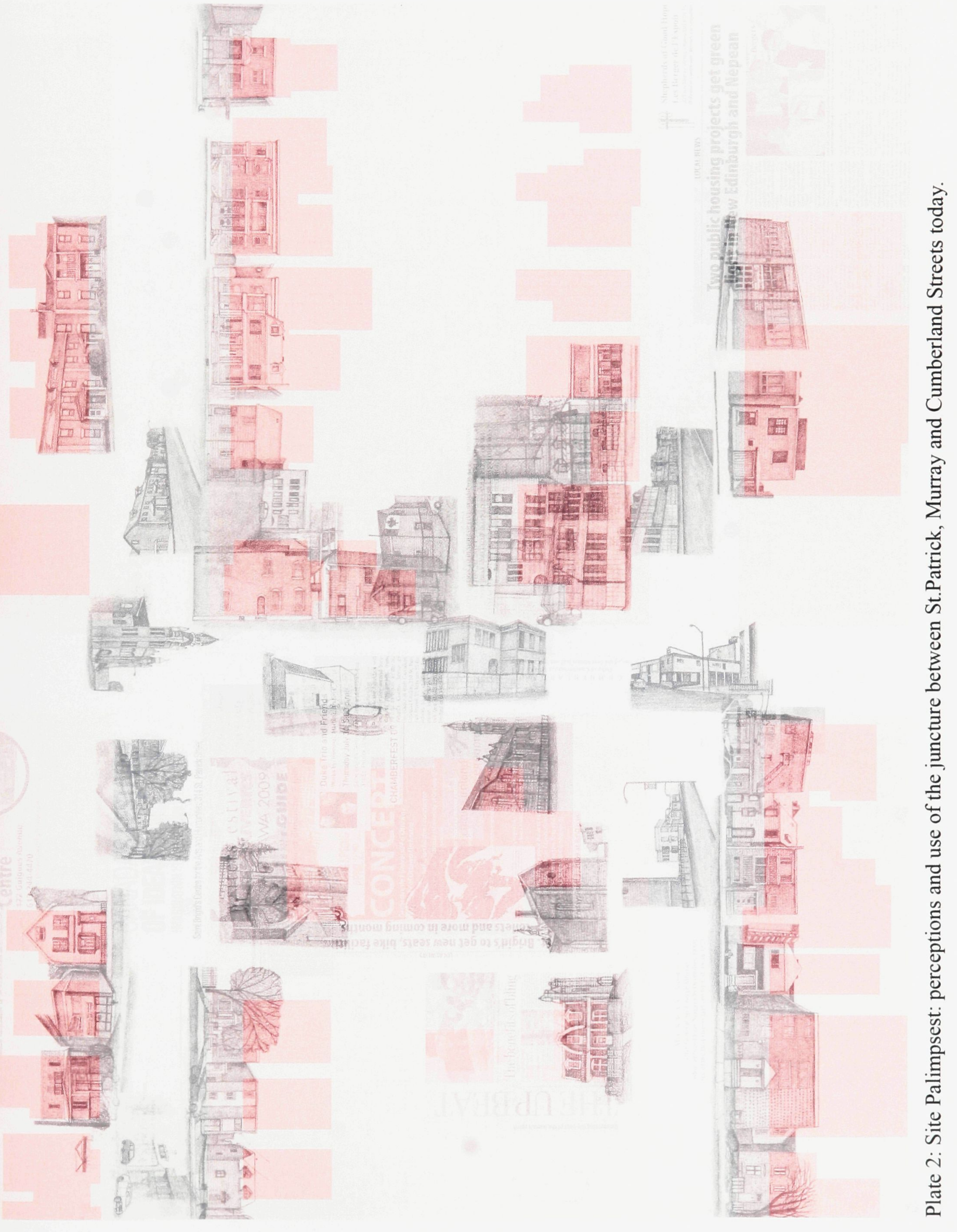



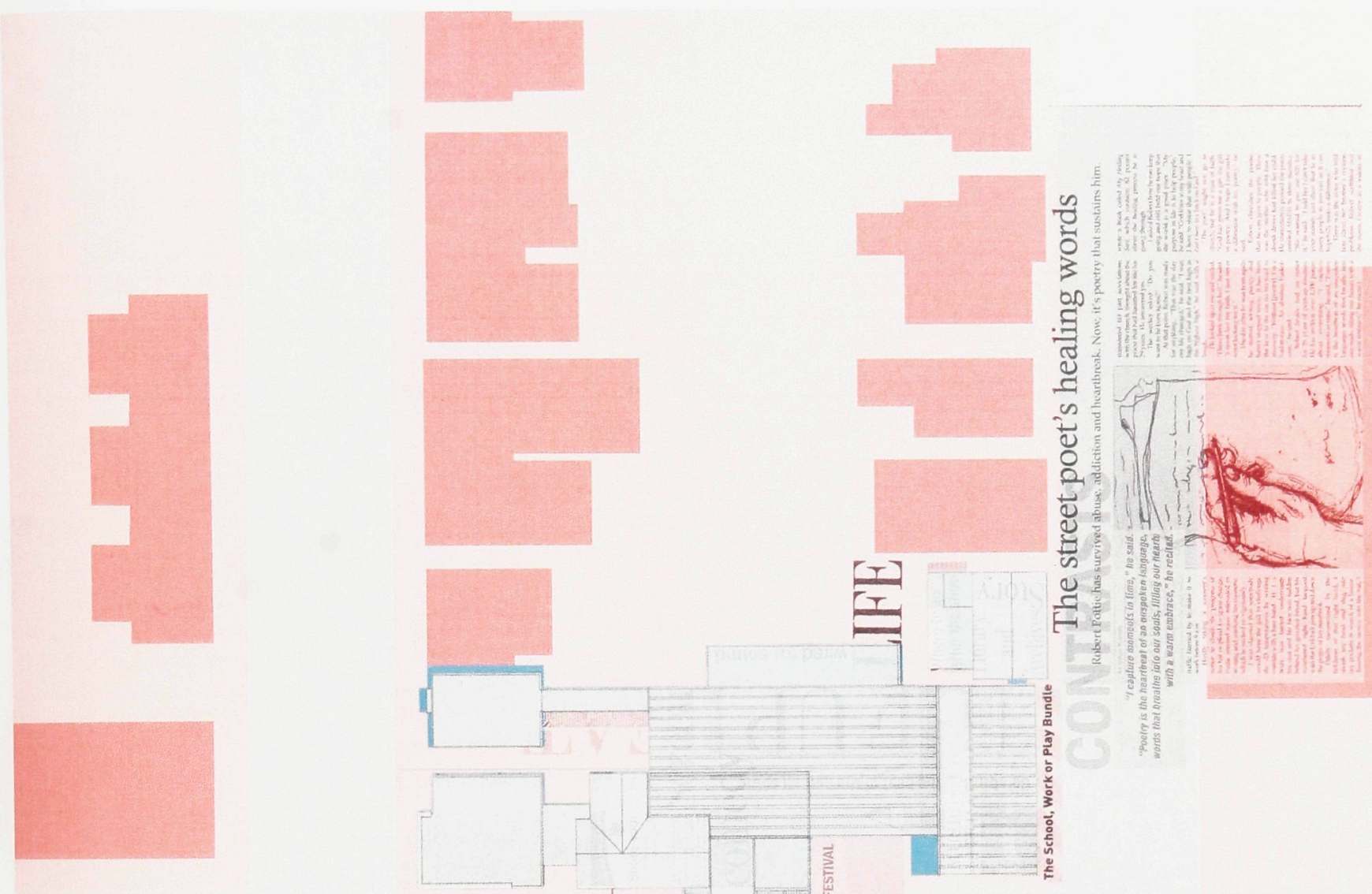


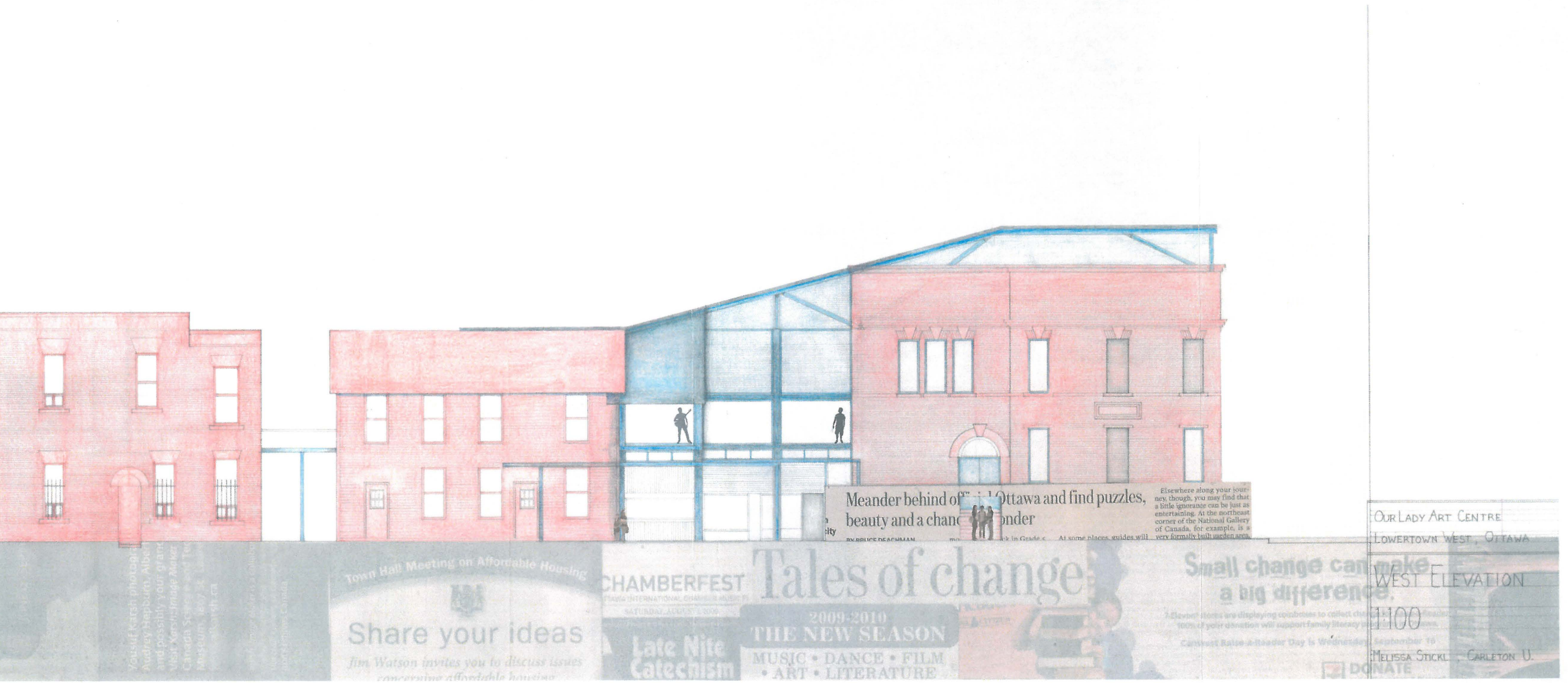

Plate 4: West Elevation of Our Lady Community Art Centre, Live / Work Residence for OCH Youth and Artist Studios, originally drawn at 1:100 scale. 

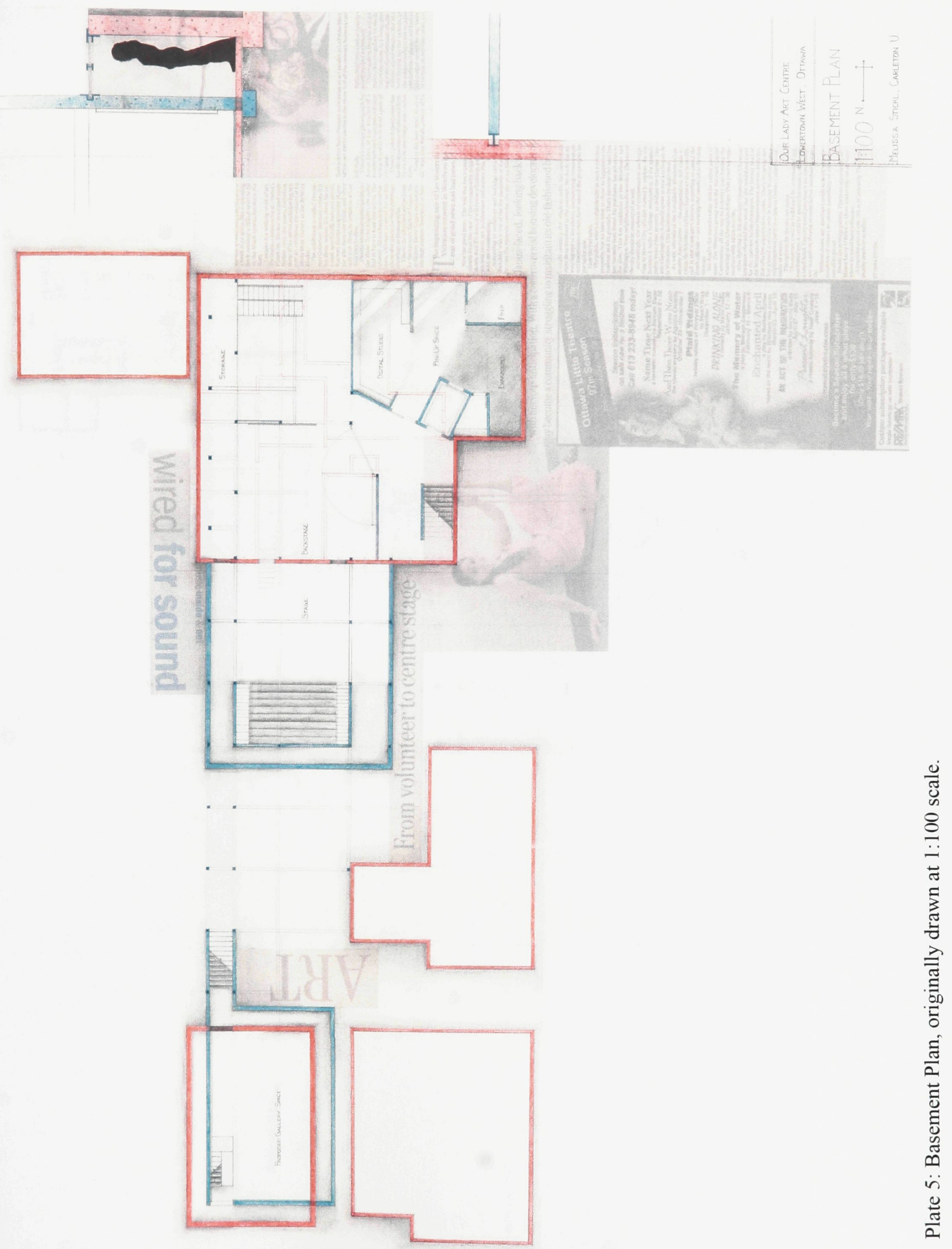


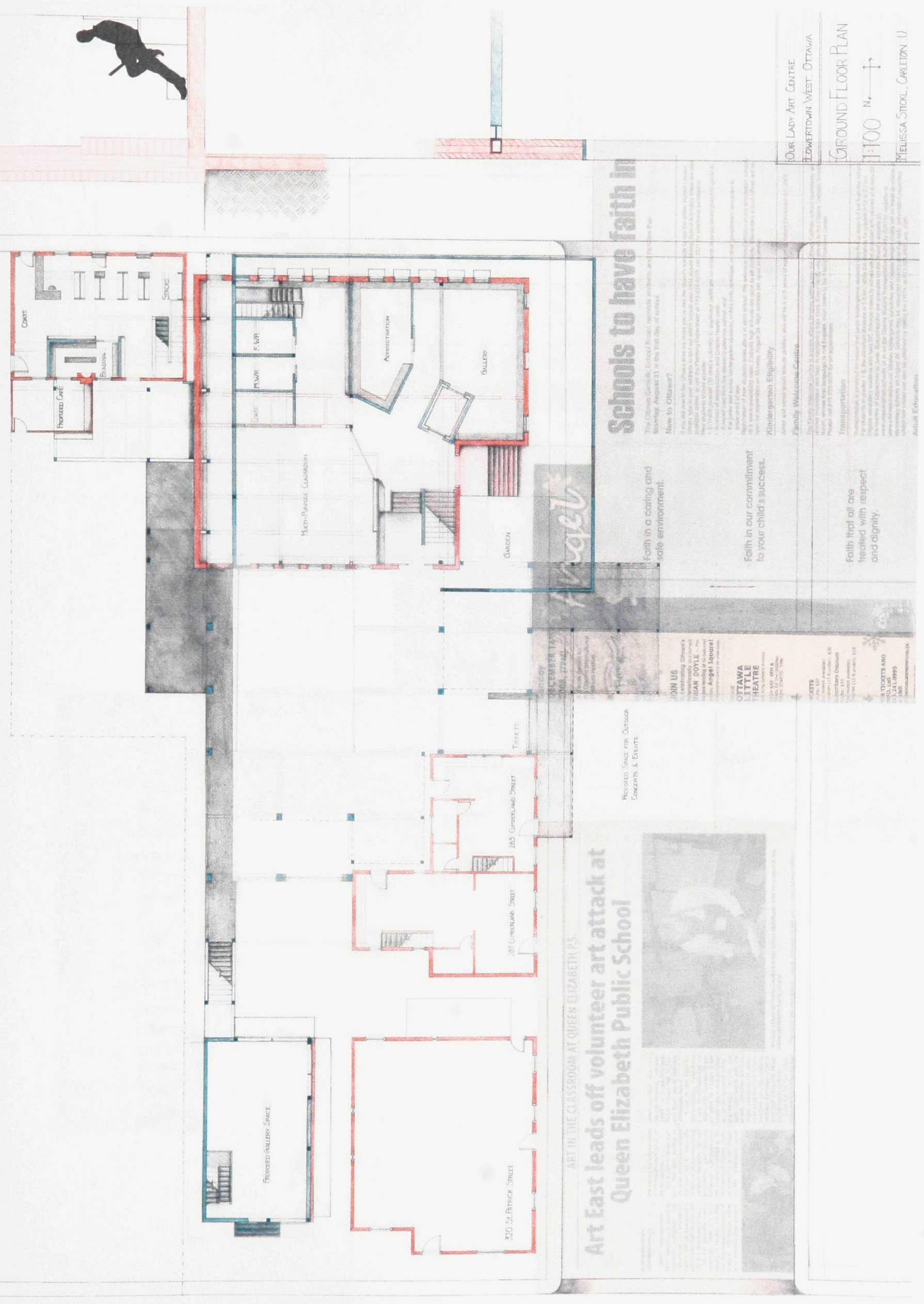

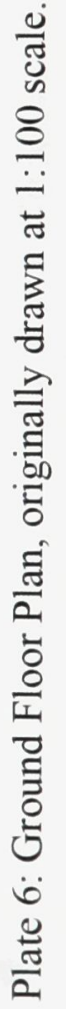




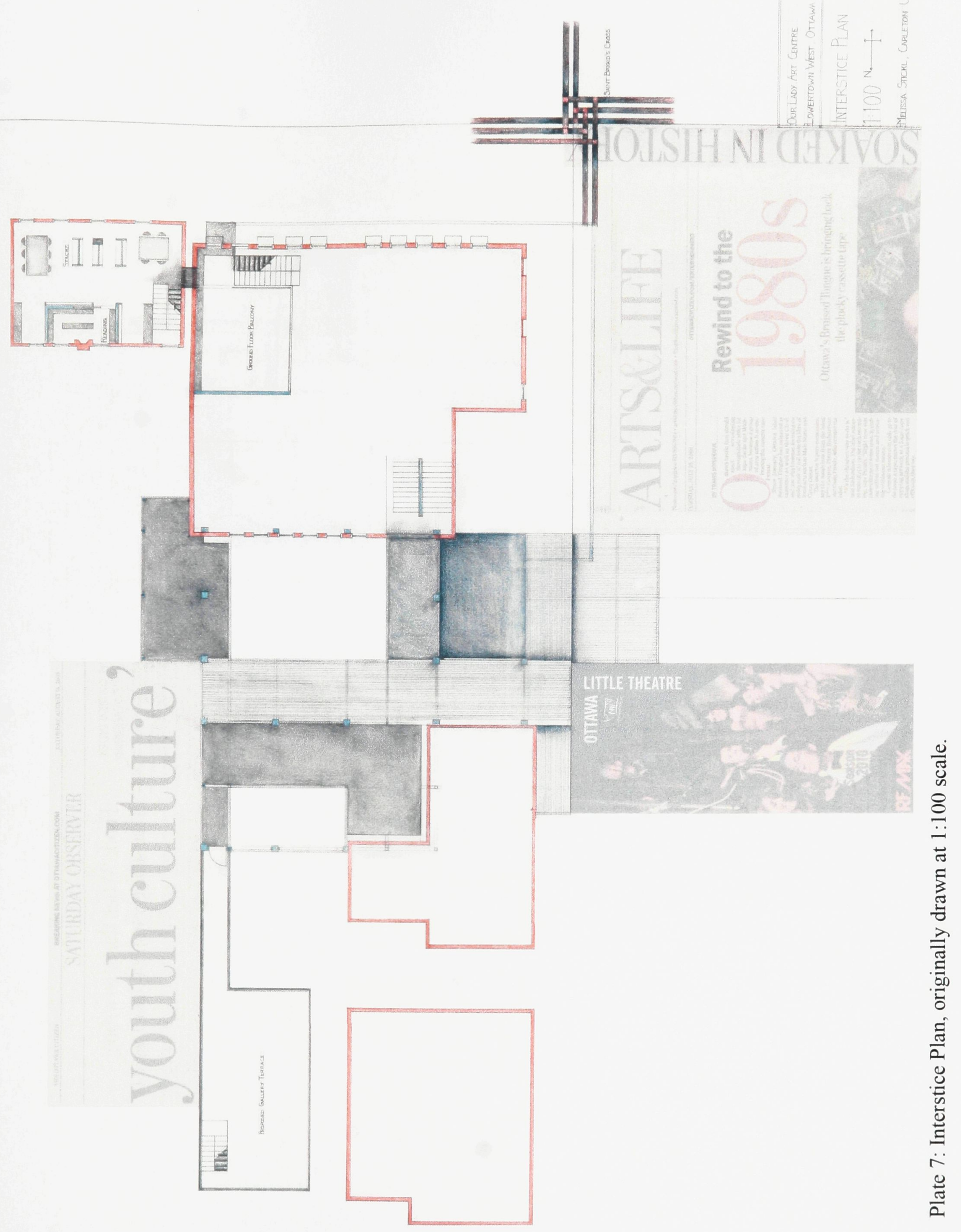




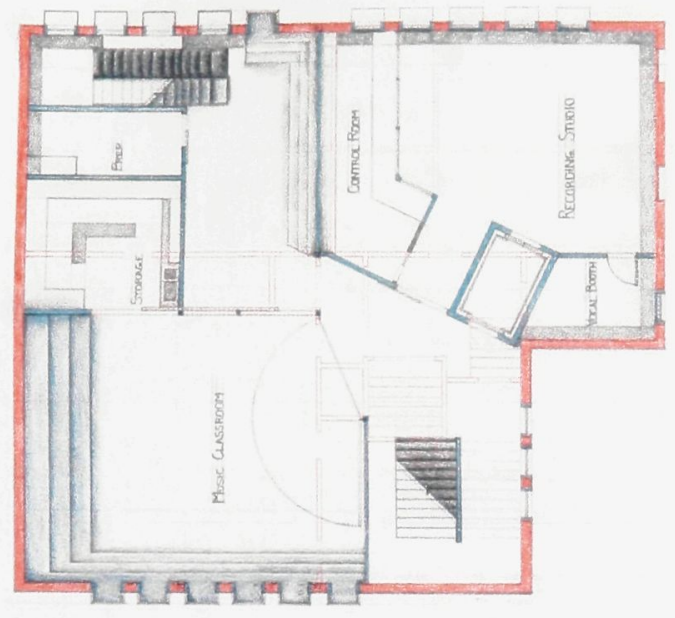

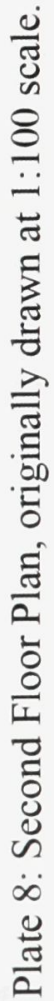




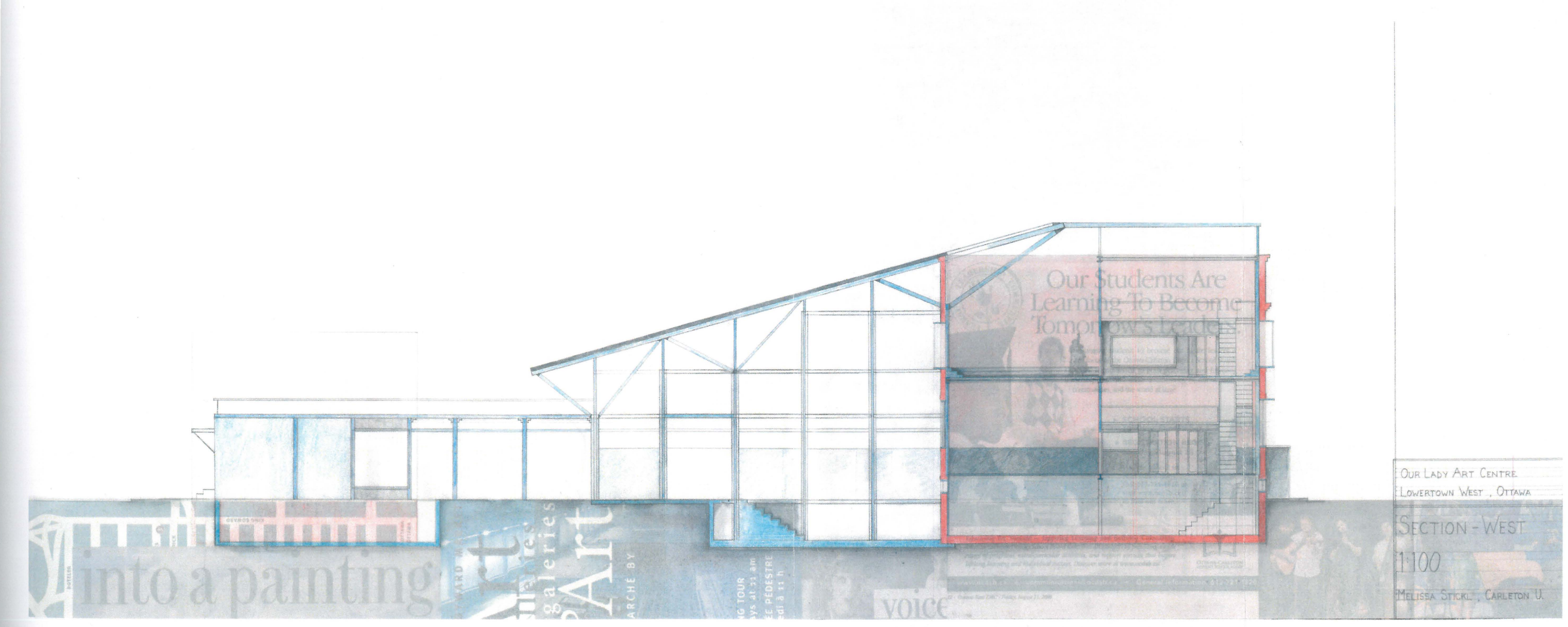

Plate 9: North / South Section emphasizing the connection between the existing school building and the new interstitial space, originally drawn at 1:100 scale 


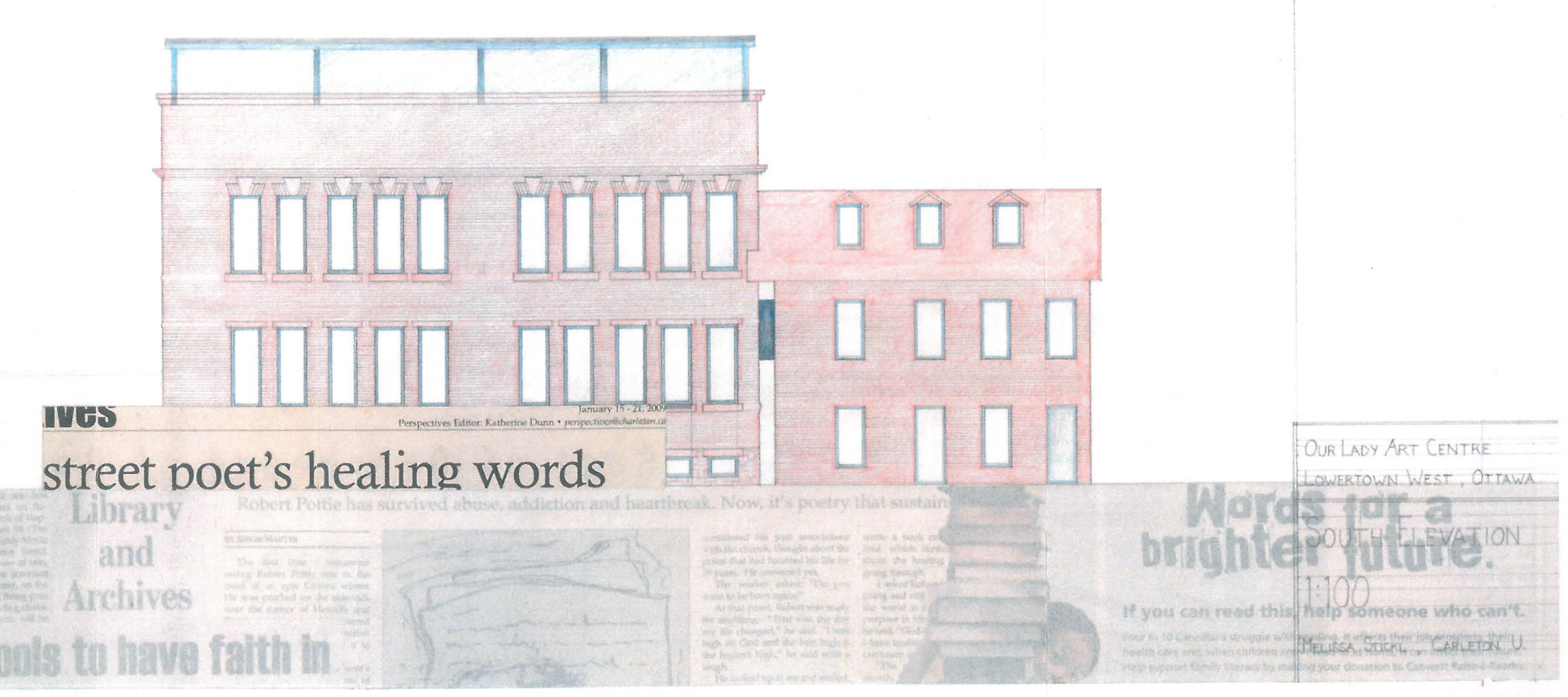

Plate 10: South Elevation of Our Lady Community Art Centre, originally drawn at 1:100 scale. 


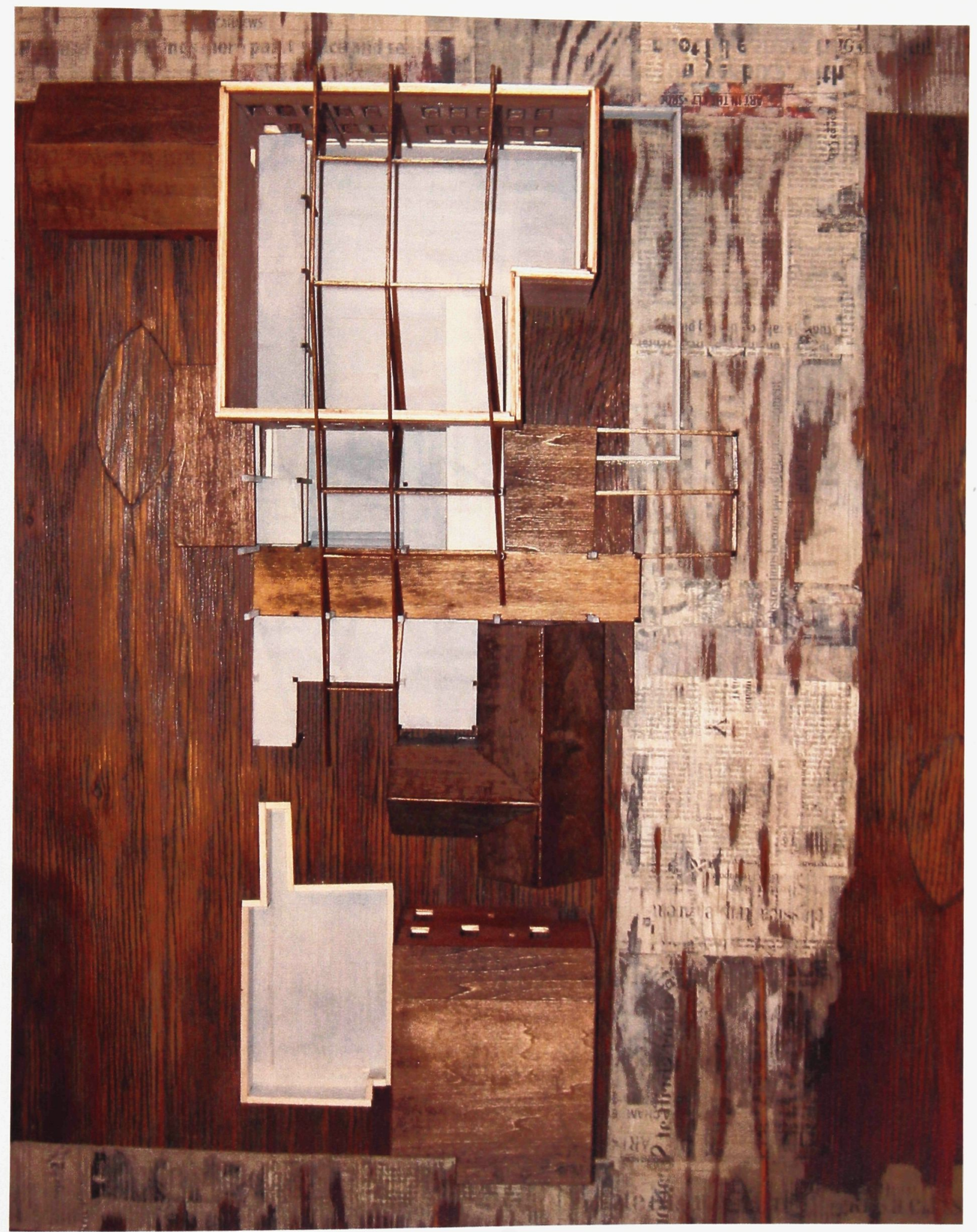

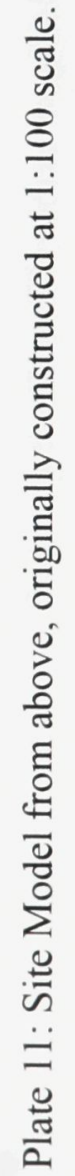




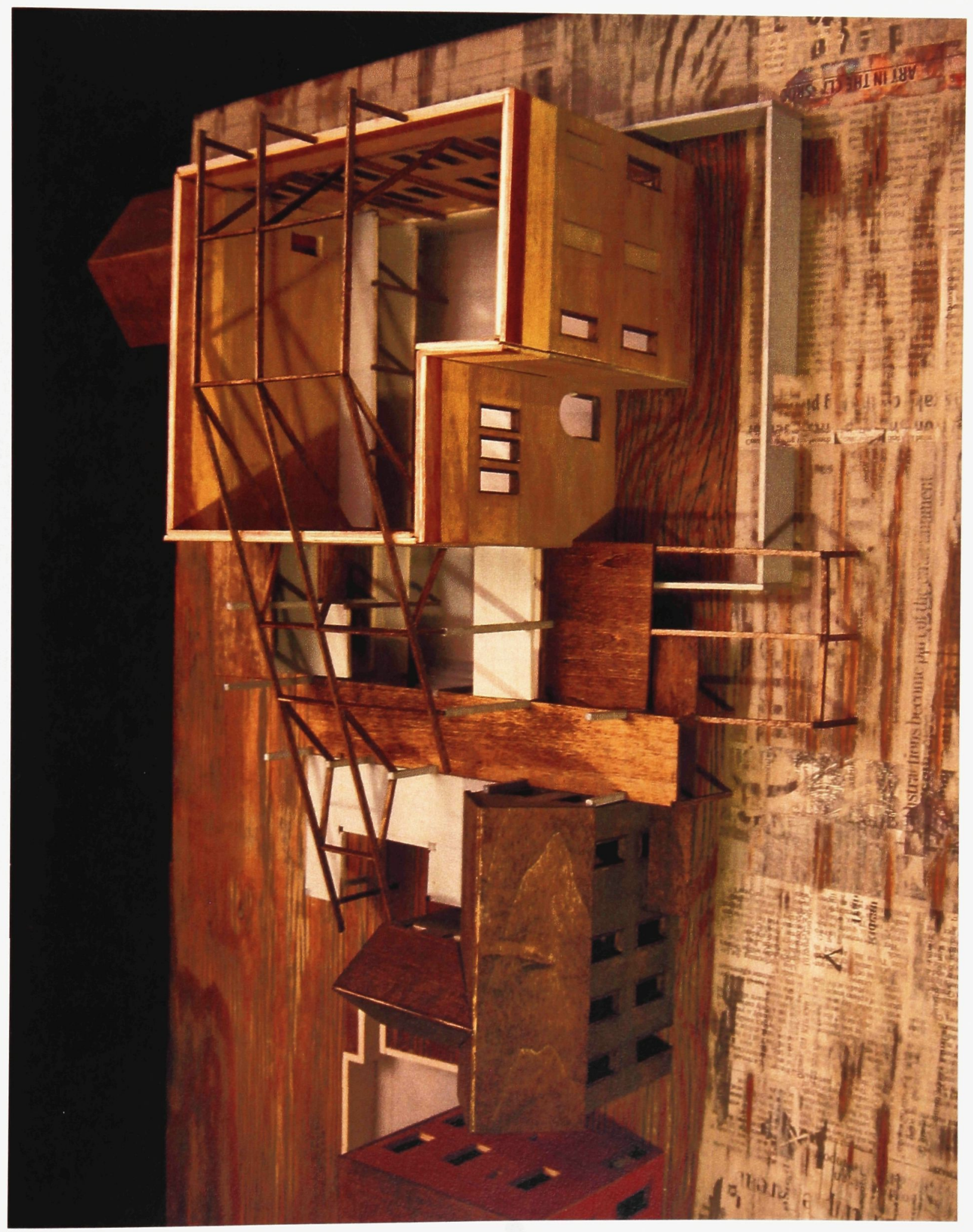

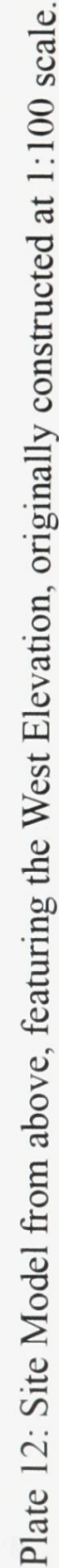




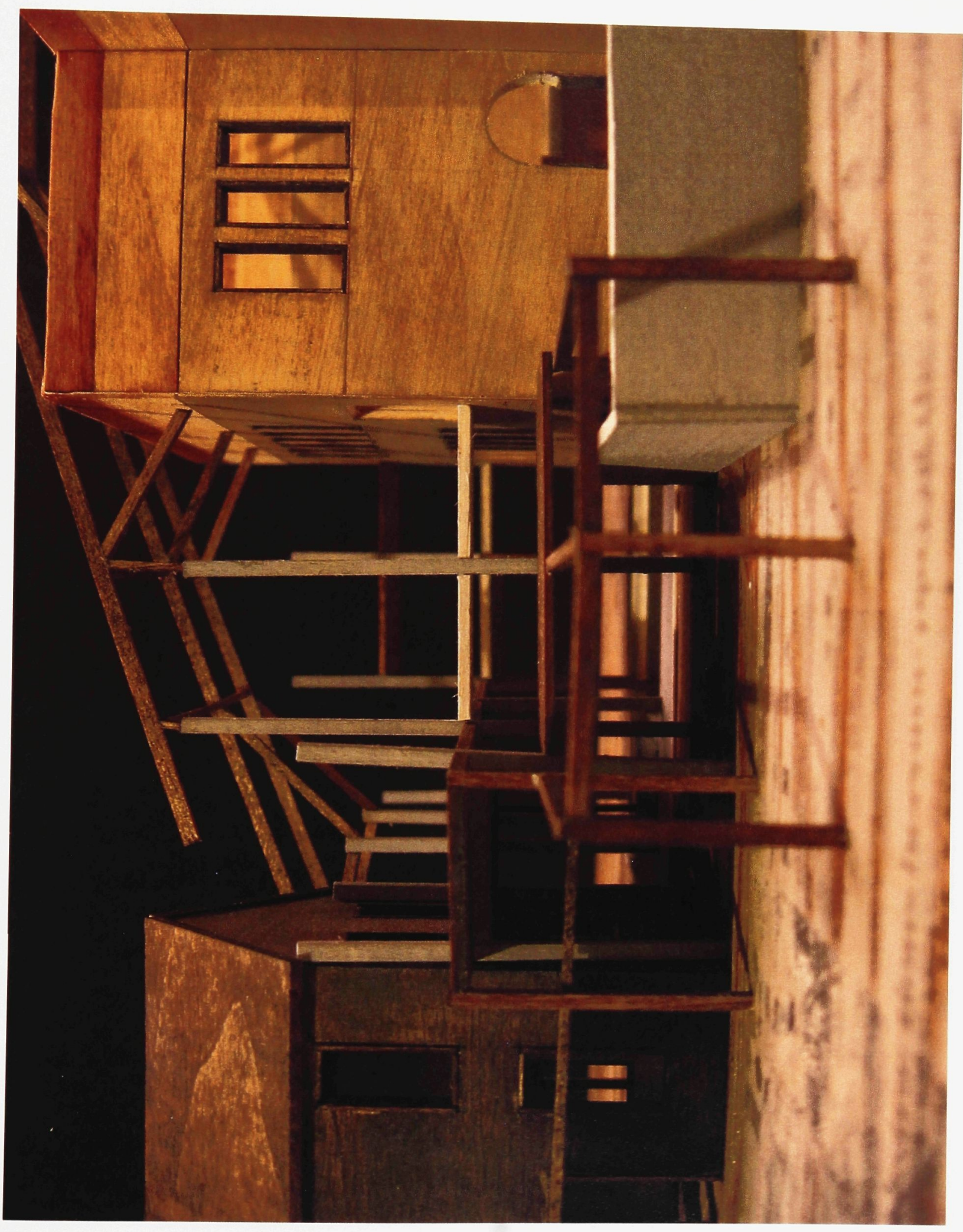

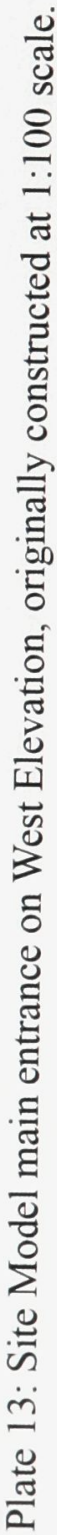




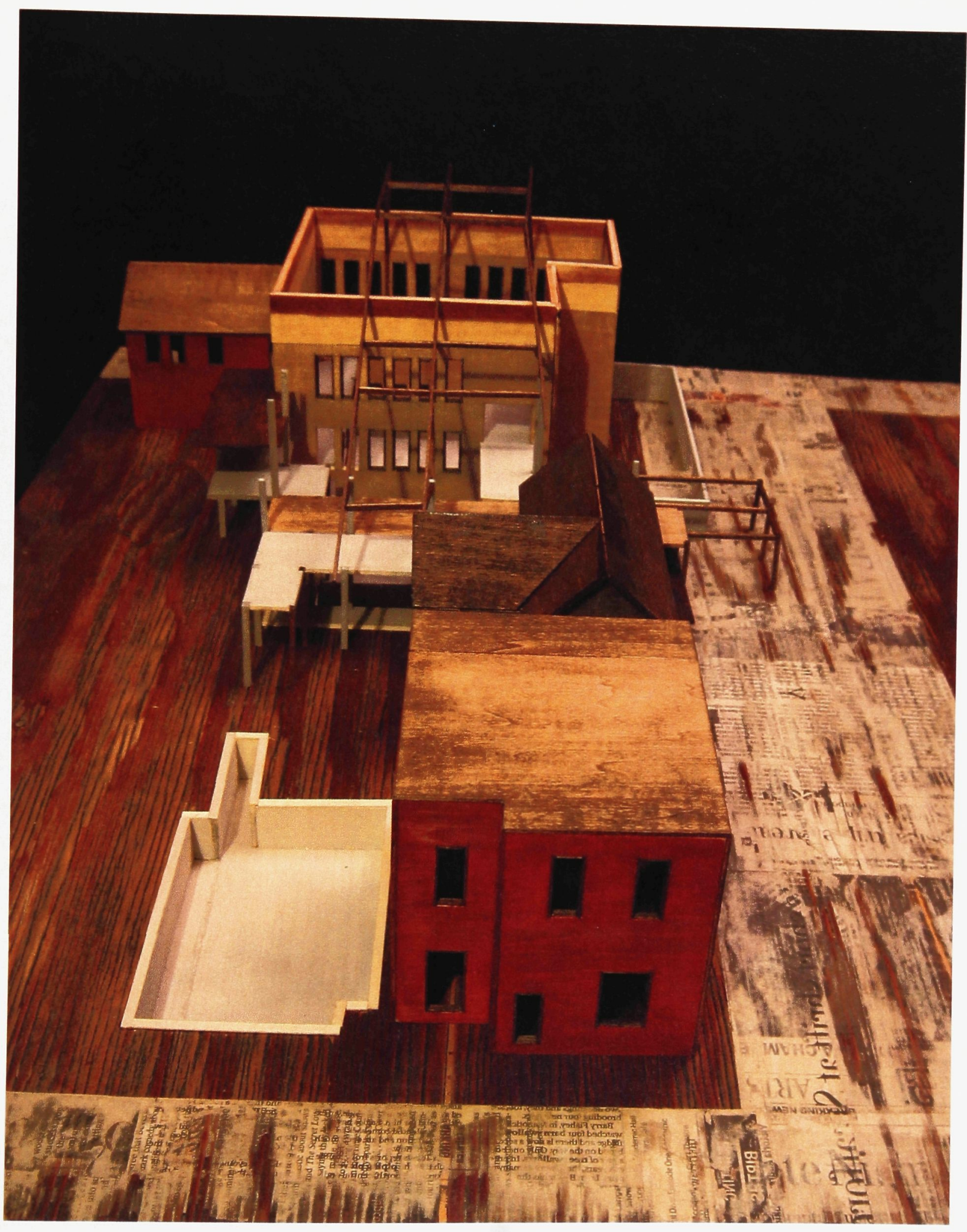

Plate 14: Site Model from above, featuring the North Elevation, originally constructed at 1:100 scale. 


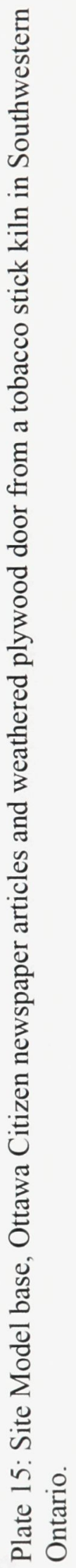



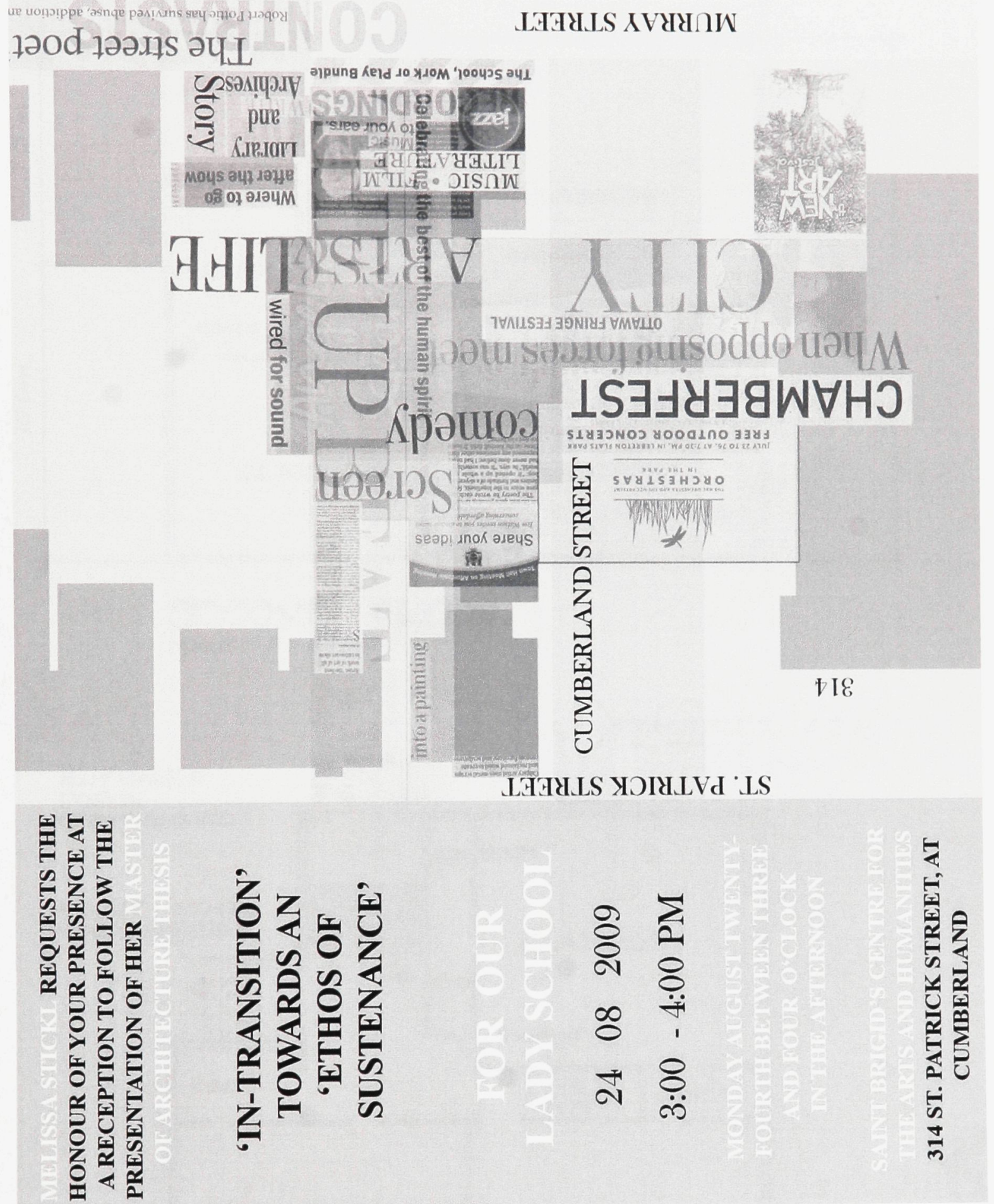

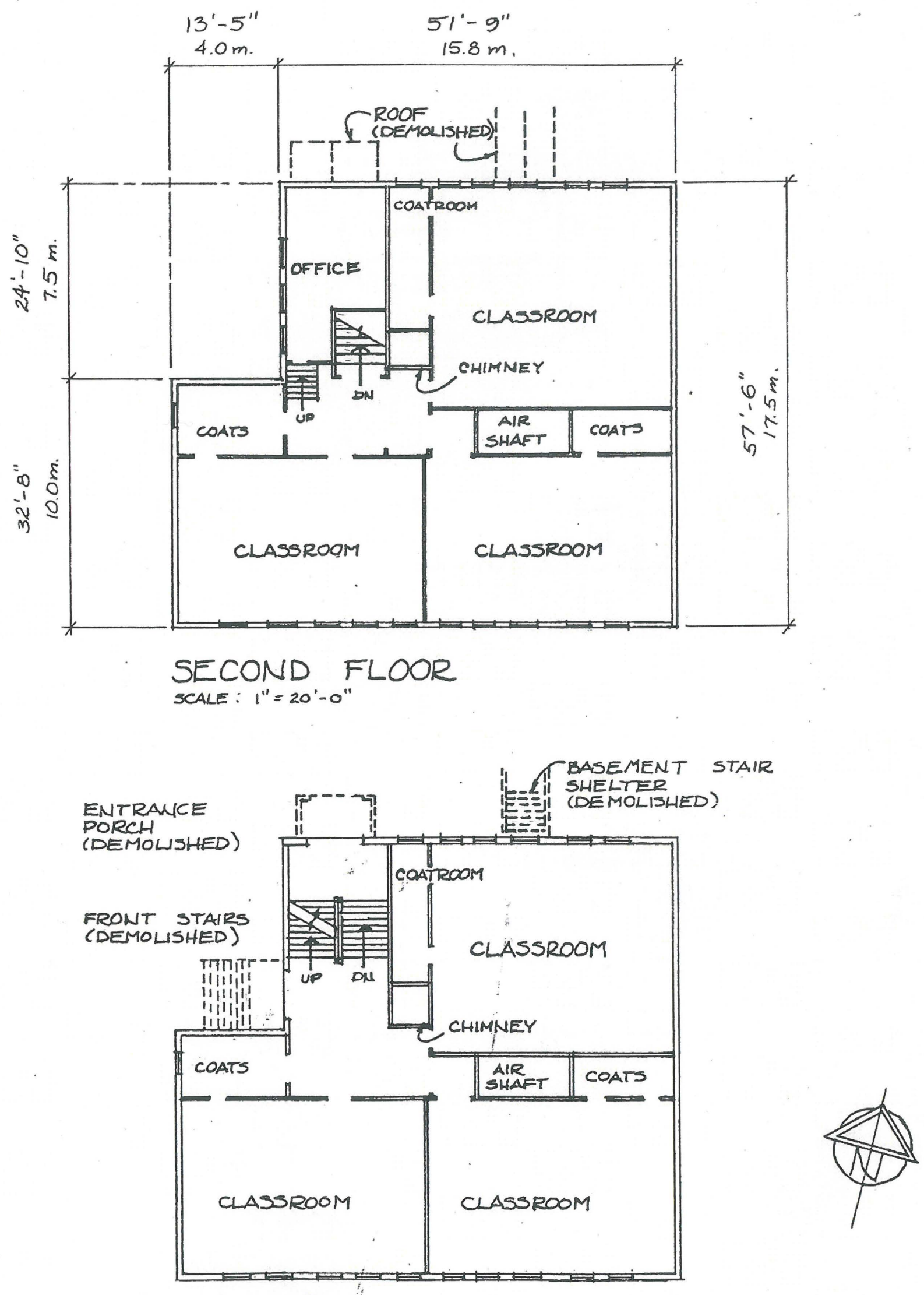

FIRST FLOOR

SCALE: $l^{\prime \prime}=20^{\circ} 0^{\circ}$ 

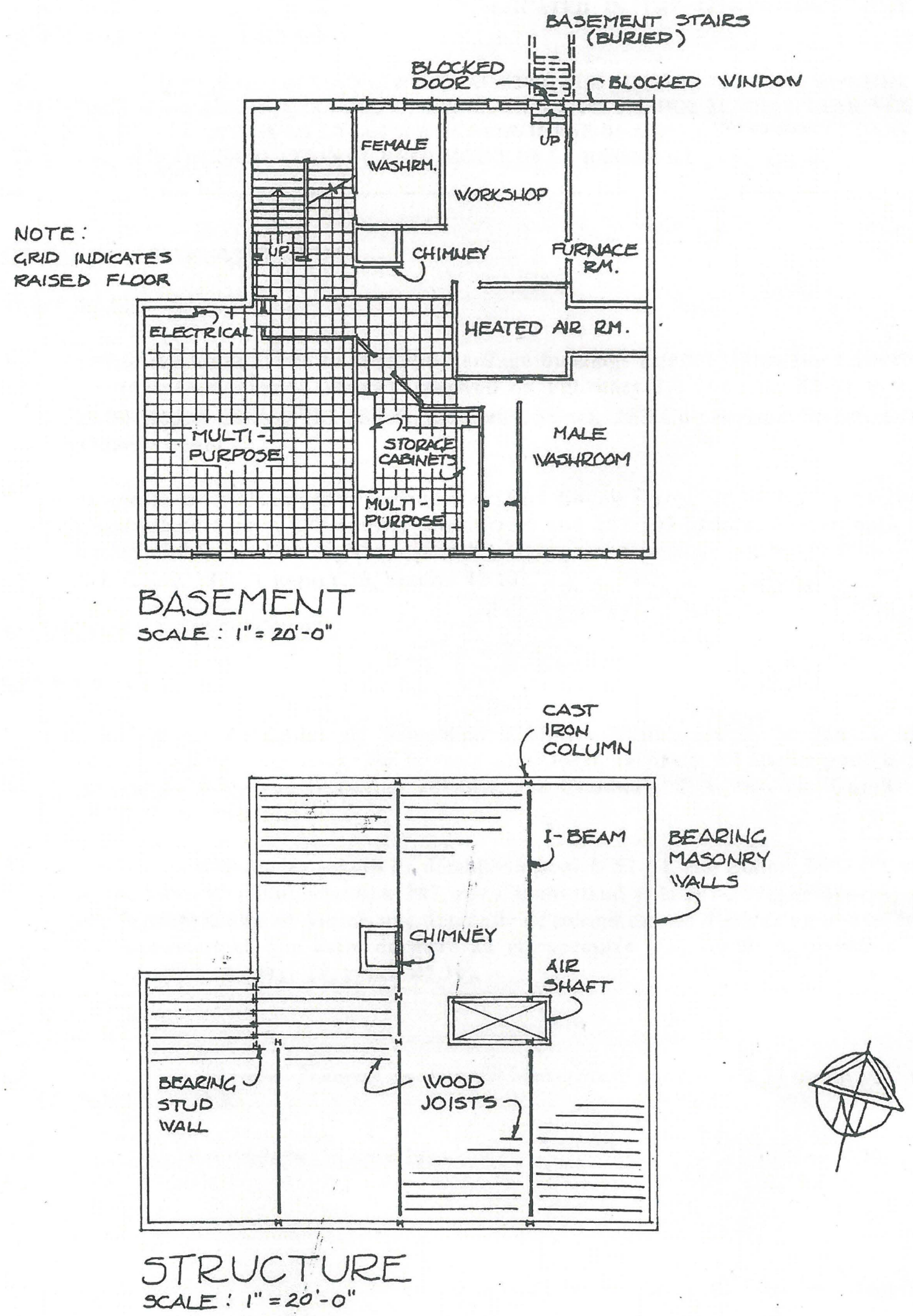
1. APPLICATION TO DEMOLISH FIVE BUILDINGS AT 52-54 BOLTON, 78-80 BOLTON, 281-283 CUMBERLAND, 287 CUMBERLAND AND 207-209 MURRAY STREET, DESIGNATED UNDER PART V OF THE ONTARIO HERITAGE ACT, LOCATED IN THE LOWERTOWN WEST HERITAGE CONSERVATION DISTRICT

DEMANDE EN VUE DÉMOLIR CINQ ÉDIFICES AU 52-54, RUE BOLTON, 78-80, RUE BOLTON, 281-283, RUE CUMBERLAND, 287, RUE CUMBERLAND ET 207-209, RUE MURRAY, DÉSIGNÉS EN VERTU DE LA PARTIE V DE LA LOI SUR LE PATRIMOINE DE L'ONTARIO ET SITUÉS DANS LE DISTRICT DE CONSERVATION DU PATRIMOINE DE LA BASSE-VILLE OUEST

\section{COMMITTEE RECOMMENDATIONS}

That Council:

1. refuse the applications to demolish heritage buildings located within the Lowertown West Heritage Conservation District, received on February 27, 2005 for 52-54 Bolton Street, 78-80 Bolton Street, 281-283 Cumberland Street, 287 Cumberland Street, and 207-209 Murray Street

2. refuse to issue a demolition permit for 52-54 Bolton Street, 78-80 Bolton Street, 281-283 Cumberland Street, 287 Cumberland Street and 207-209 Murray Street, until the owner has applied for and been given a permit to erect a new building on the site (Ontario Heritage Act, R.S.O. 1990, Chapter.18, Section 42.10).

\section{RECOMMANDATIONS DU COMITÉ}

Que le Conseil :

1. refuse les demandes de démolition d'édifices historiques situés dans le district de conservation du patrimoine de la basse-ville Ouest, reçues le 27 février pour le 52-54, rue Bolton, le 78-80, rue Bolton, le 281-283, rue Cumberland, le 287, rue Cumberland et le 207-209, rue Murray;

2. refuse de délivrer un permis de démolition pour le 52-54, rue Bolton, le 78-80, rue Bolton, le 281-283, rue Cumberland, le 287, rue Cumberland et le 207-209, rue Murray jusqu'à ce que le propriétaire ait soumis une demande de permis en vue d'ériger un nouvel édifice à ces emplacements et que cette dernière ait été acceptée (Loi sur le patrimoine de l'Ontario, L.R.O. 1990, chapitre 18, article 42.10).

\section{DOCUMENTATION}

1. Deputy City Manager, Planning and Growth Management report dated 14 March 2005 (ACS2005PGM-APR-0098).

2. Extract of Draft Minutes, 26 April 2005. 
Local Architectural Conservation Advisory Committee

Comité consultatif sur la conservation de l'architecture locale

$$
\text { and / et }
$$

Planning and Environment Committee

Comité de l'urbanisme et de l'aménagement

and Council / et au Conseil

14 March 2005 / le 14 mars 2005

Submitted by/Soumis par : Ned Lathrop, Deputy City Manager/Directeur municipal adjoint, Planning and Growth Management / Urbanisme et Gestion de la croissance

Contact Person/Personne ressource : Grant Lindsay, Manager /Gestionnaire, Development Approvals / Approbation des demandes d'aménagement

(613) 580-2424x 13242, grant.lindsay@ottawa.ca

Rideau-Vanier (12)

Ref $N^{\circ}:$ ACS2005-PGM-APR-0098

SUBJECT: APPLICATION TO DEMOLISH FIVE BUILDINGS AT 52-54 BOLTON, 78-80 BOLTON, 281-283 CUMBERLAND, 287 CUMBERLAND AND 207-209 MURRAY STREET, DESIGNATED UNDER PART V OF THE ONTARIO HERITAGE ACT, LOCATED IN THE LOWERTOWN WEST HERITAGE CONSERVATION DISTRICT.

OBJET: $\quad$ DEMANDE EN VUE DÉMOLIR CINQ ÉDIFICES AU 52-54, RUE BOLTON, 78-80, RUE BOLTON, 281-283, RUE CUMBERLAND, 287, RUE CUMBERLAND ET 207-209, RUE MURRAY, DÉSIGNÉS EN VERTU DE LA PARTIE V DE LA LOI SUR LE PATRIMOINE DE L'ONTARIO ET SITUÉS DANS LE DISTRICT DE CONSERVATION DU PATRIMOINE DE LA BASSE-VILLE OUEST

\section{REPORT RECOMMENDATION}

That the Local Architectural Conservation Advisory Committee recommend that Planning and Environment Committee recommend that Council: 
1. refuse the applications to demolish heritage buildings located within the Lowertown West Heritage Conservation District, received on February 27, 2005 for 52-54 Bolton Street, 78-80 Bolton Street, 281-283 Cumberland Street, 287 Cumberland Street, and 207-209 Murray Street

2. refuse to issue a demolition permit for 52-54 Bolton Street, 78-80 Bolton Street, 281-283 Cumberland Street, 287 Cumberland Street and 207-209 Murray Street, until the owner has applied for and been given a permit to erect a new building on the site (Ontario Heritage Act, R.S.O. 1990, Chapter.18, Section 42.10).

\section{RECOMMANDATION DU RAPPORT}

Que le Comité sur la conservation de l'architecture locale préconise au Comité de l'urbanisme et de l'environnement de recommander au Conseil :

3. de refuser les demandes de démolition d'édifices historiques situés dans le district de conservation du patrimoine de la basse-ville Ouest, reçues le 27 février pour le 52-54, rue Bolton, le 78-80, rue Bolton, le 281-283, rue Cumberland, le 287, rue Cumberland et le 207-209, rue Murray;

4. de refuser de délivrer un permis de démolition pour le 52-54, rue Bolton, le 78-80, rue Bolton, le 281-283, rue Cumberland, le 287, rue Cumberland et le 207-209, rue Murray jusqu'à ce que le propriétaire ait soumis une demande de permis en vue d'ériger un nouvel édifice à ces emplacements et que cette dernière ait été acceptée (Loi sur le patrimoine de l'Ontario, L.R.O. 1990, chapitre 18, article 42.10).

\section{Local Architectural Conservation Advisory Committee Recommendation - 24 March 2005}

LACAC strongly supports the departmental recommendation.

\section{BACKGROUND}

The Lowertown West Heritage Conservation District was designated by City Council in 1993 as a heritage conservation district under Part V of the Ontario Heritage Act.

The Heritage Conservation District Study involved the analysis of the heritage character of the area, individual analysis and scoring of each building in the District to determine its category on the City's Heritage Reference List and the development of a "Heritage Conservation District Plan" to guide the management of the heritage conservation district.

The buildings that are the subject of this application under the Ontario Heritage Act are all part of the Lowertwon West Heritage Conservation District and all were evaluated. A brief synopsis of each one follows (see also Heritage Survey Forms, page 1, Documents 2-6): 
Category 3. This is a flat-roofed, two storey double, with a carriage way, constructed in 1894. It was originally occupied by Victor Lepage, a clerk and Jean Baptiste Lepage, a draftsman. Heritage staff have toured it and confirmed that it is in very poor condition. Retention of the front façade, including carriageway would be supported in the context of a subsequent application to alter under the Ontario Heritage Act.

\section{8-80 Bolton Street}

Category 2. This is a side-gabled, one and a half storey double house with pedimented dormer windows. Its design reflects the early vernacular tradition of Lowertown. It was occupied by a series of labourers throughout the 19th and 20th centuries. Its present condition is unknown.

\section{1-283 Cumberland}

Category 3. This is a two storey, side-gabled structure constructed between 1861 and 1872 . It was a residential dwelling with a carriage maker in the rear year for many years. It has been altered and had much of its original detail removed but it retains the profile of an 19th century Lowertown dwelling. The structure may have been built as a one storey building and had an additional storey added in late 19th century. It is currently occupied.

\section{Cumberland, Our Lady Girls' School}

Category 2. This school was constructed in 1904, but there was a Roman Catholic Girls' School on the site as early as 1886 . There was a boys' school, St. Brigid's, at the other end of the block. Both schools were associated with the parish church, St. Brigid's on St. Patrick Street. The building is a two storey brick structure with a flat roof and stone window surrounds. It was re-roofed in 2000 and a permit to convert the building to apartments was issued the same year. Currently unoccupied, condition unknown.

\section{7-209 Murray Street}

Category 2. This two storey, side gabled double was constructed in the 1870 s and displays the di-chromatic (red and white) brick popular in Canada in that decade. The house was built by Stanislas Hotte, who occupied one side and rented out the other. Like many Lowertown buildings, there were light industrial uses in the rear yard - in this case, a carpenter's yard. There was a fire in the building in the last two years, but the extent of the damage and the condition of the building is not known.

The other component of the Study, the Heritage Conservation District Plan, has been used by staff since the creation of the District when considering applications and new development within the District. 


\section{Recommendation 1}

Heritage Conservation Districts are created to preserve the character of neighbourhoods and areas that convey a special sense of time and place. The City Council Approved Official Plan, provides for the creation of heritage conservation districts through policy 2.5.5.1 and 2.5.5. 2 which states that "The City will provide for the conservation of cultural heritage resources for the benefit of the community and posterity ... groups of buildings, cultural landscapes and areas of the City will be designated as Heritage Conservation Districts under Part V of the Ontario Heritage Act."

The City Council approved Lowertown West Heritage Conservation District Plan also has guidelines regarding demolitions in the District. Section 7.5.4 of the Guidelines states that "As a general principle, demolition of structures within the District will not be recommended for approval by City Council."

The 2005 Provincial Policy Statement issued under the authority of Part 3 of the Planning Act, which came into force on March 1, 2005 also addresses the issue of the demolition of designated heritage resources stating that:

\subsection{Cultural Heritage and Archaeology}

\subsubsection{Significant built heritage resources and significant cultural heritage landscapes shall be conserved.}

In addition, all of the buildings, except Our Lady School, contain rental housing units. The City has policies regarding the demolition of rental housing units. Section 4.5.5 of the City Council Approved Official Plan, states that "Applications for demolition of housing units will not be approved unless replacement units are provided." This policy enforces the Demolition Control policies established through Section 33 of the Planning Act that allow Council to refuse to issue a demolition permit unless a building permit has been issued. The entire former City of Ottawa is a Demolition Control area.

\section{Recommendation 2}

When Council refuses an application to demolish a building under the Ontario Heritage Act, Section 42 (10) of that Act gives Council the authority to refuse to issue a demolition permit until "the owner has applied to council under this section and been given a permit to erect a new building on the site .." This ensures the preservation of designated buildings threatened with demolition indefinitely.

Given the policies and guidelines above, the Department does not support the applications for the demolition of these buildings. The buildings have all been scored according to Council-approved guidelines and have been placed in Category 2 or 3 , each is an integral part of a streetscape that contributes to the heritage character of the District that is being protected.

The Department has not received applications for replacement buildings, nor have cultural heritage impact statements on the condition of the structures been received. As there are no plans for replacement buildings and no evidence (apart from 52-54 Bolton) that the condition of the existing structures warrants their removal, the Department can not support the demolitions. Furthermore, the removal of the existing heritage buildings on the sites would continue to make it difficult to achieve the aims of the Lowertown West Heritage Conservation District to preserve the integrity of the District and to manage change in such a way as to enhance the character of the District. 
Ac, Conservation Advisory Committee (LACAC) and Planning and Environment Committee tee meetings and were provided with comment sheets to be returned to LACAC.

The Lowertown West Residents' Association was informed of the project.

Heritage Ottawa was informed of the proposed demolitions.

Georges Bédard, the Ward Councillor, is aware of these applications.

FINANCIAL IMPLICATIONS

N/A

\section{SUPPORTING DOCUMENTATION}

Document 1 Location Map, Bolton Street

Document 2 Location Map, Cumberland and Murray Streets

Document 3 Heritage Survey Form (HSF), page 1, 52 - 54 Bolton Street

Document 4 HSF, page 1, 78-80 Bolton Street

Document 5 HSF, page 1, 281-283 Cumberland Street

Document 6 HSF, page 1, 287 Cumberland Street

Document 7 HSF, page 1, 295 Cumberland Street

\section{DISPOSITION}

The Corporate Services Department, Council and Committee Services, to notify the applicant/ agent (Arnell Goldberg, Goldberg, Stronick and Stroud, 307 Gimour St., Ottawa, Ontario, K2P 0P7); the owner (Claude Lauzon, 274 Dalhousie Street, Ottawa, Ontario, K1N 7E6) and the Ontario Heritage Foundation (10 Adelaide Street, 3rd Floor, Toronto, Ontario, M5C 1J3) of City Council's decision regarding the demolitions at 52-54 Bolton, 78-80 Bolton, 281-283 Cumberland, 287 Cumberland and 207-209 Murray Street. 
Document 1

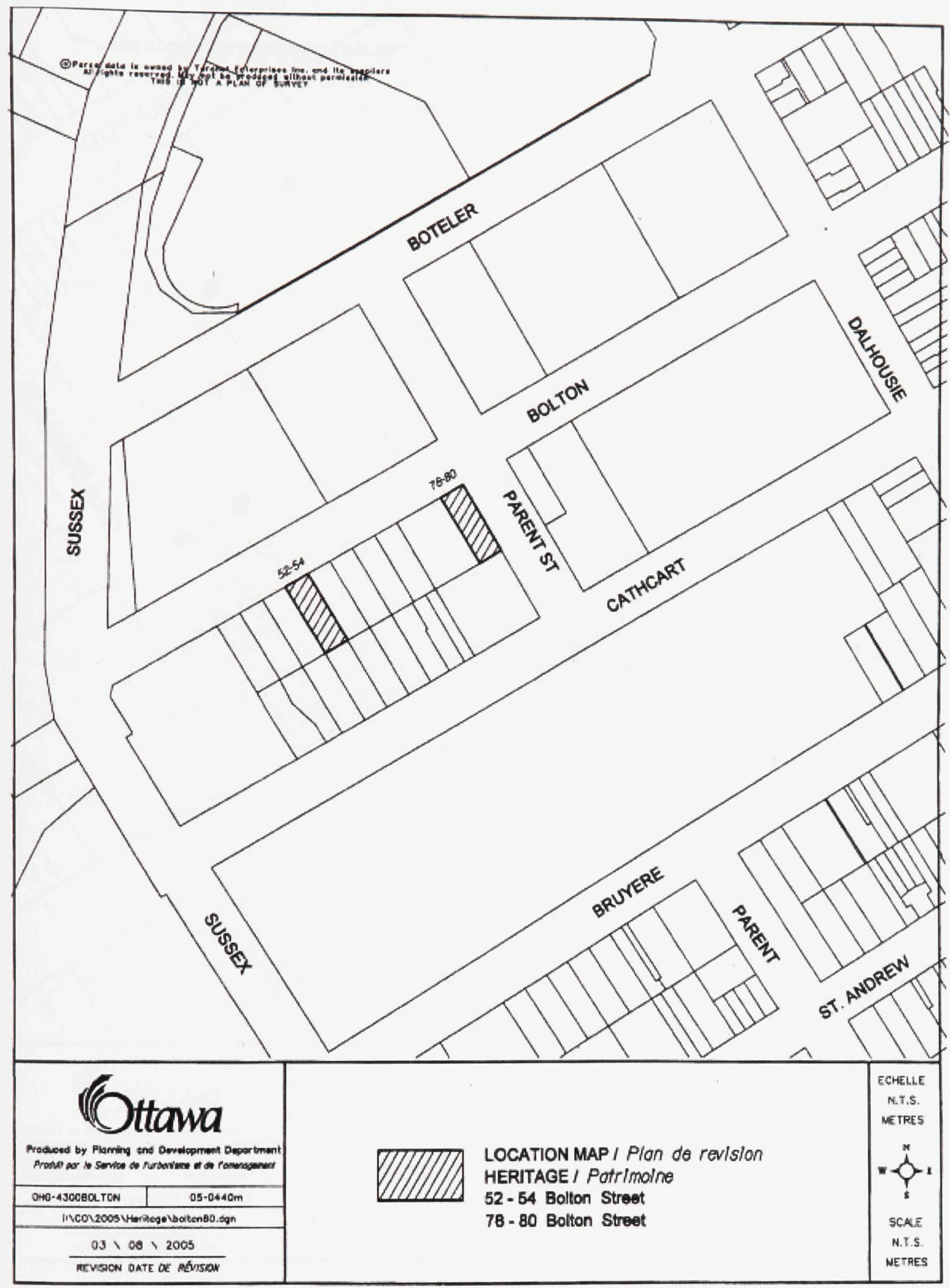




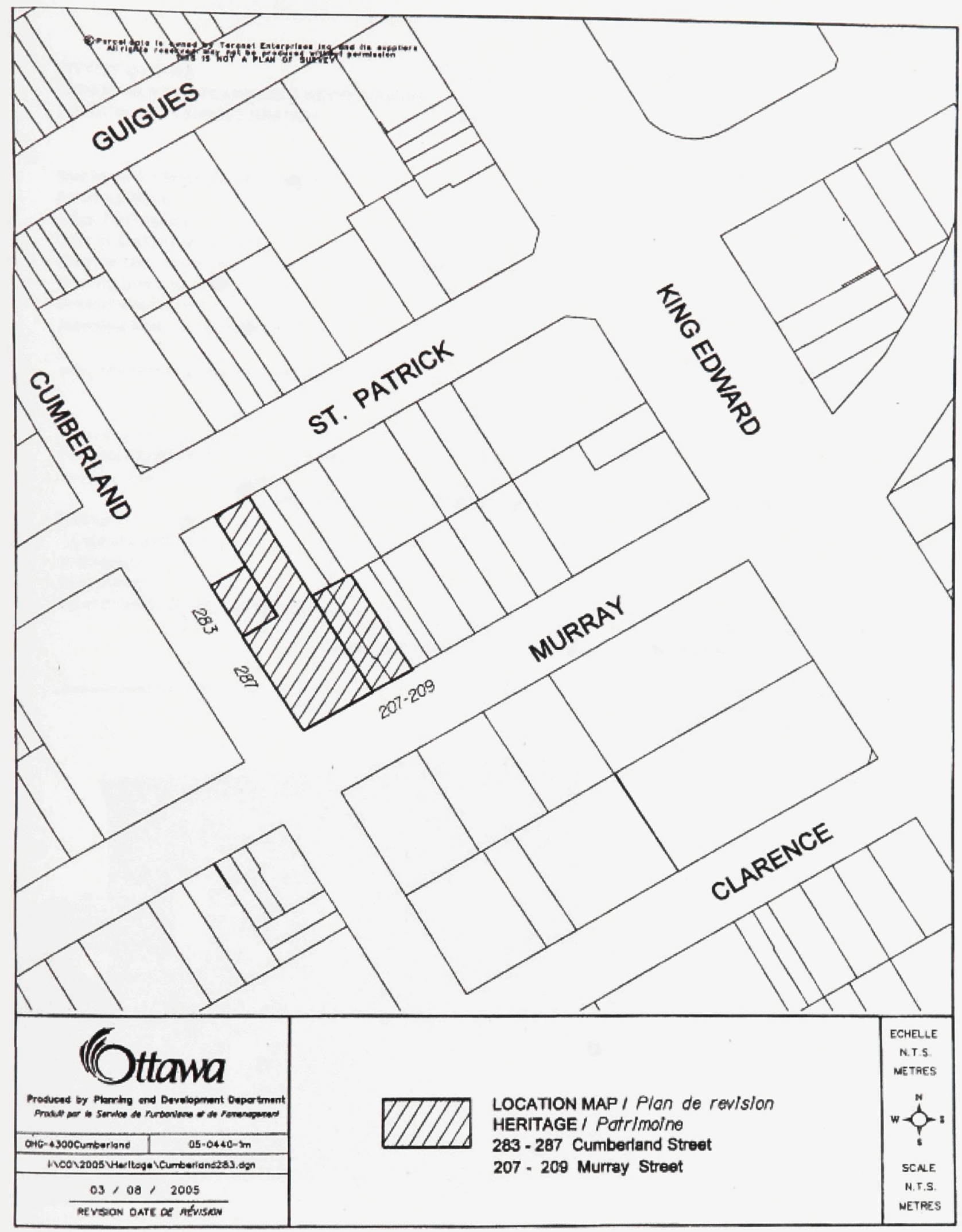


CITY OF OTTAWA

DEPARTMENT OF PLANNING \& DEVELOPMENT COMMUNITY PLANNING BRANCH

HERITAGE SURVEY

AND

EVALUATION FORM
BUILDING FILE NO.

PD : 4300 Eolton 52-54

HERITAGE DISTRICT FILE NO.

$P D$ :

Municipal Address: $52-54$ Bolton St Bullding Name

Legal Description

Date of Construction 1894

Lot E $1 / 2$ L 3 Block Botions Plan 3

Original Use residential - dupiex

Additions

Present Use residential - dupiux

Original Owner Lepage tamily

Present Zoning HR-1

Present Owner

Planning Area Lowertown West

PHASE ONE SURVEY

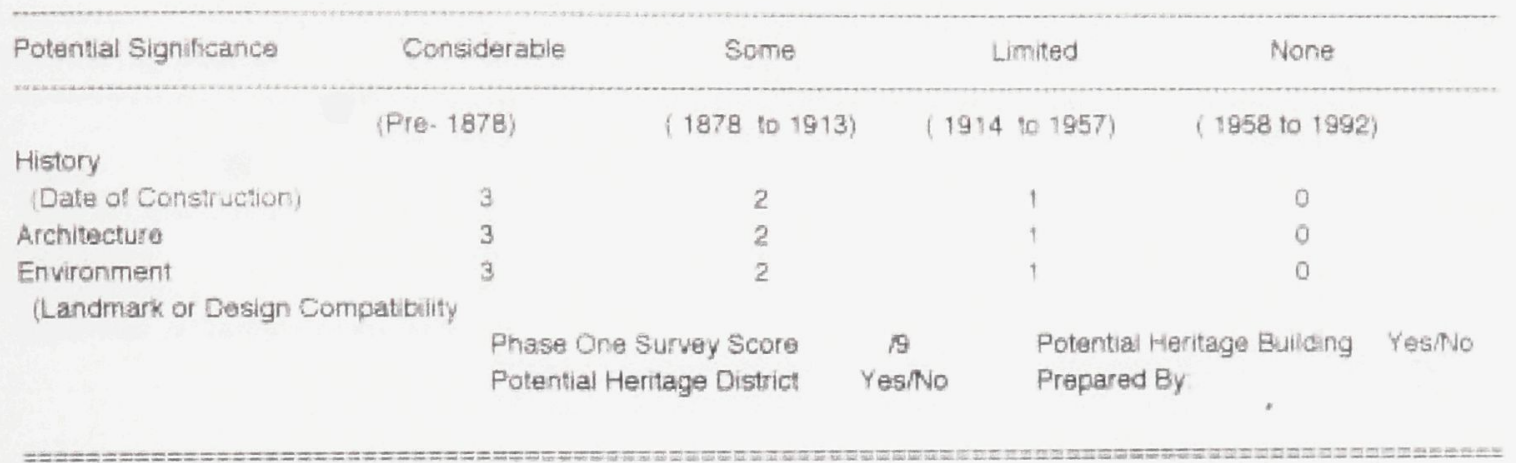

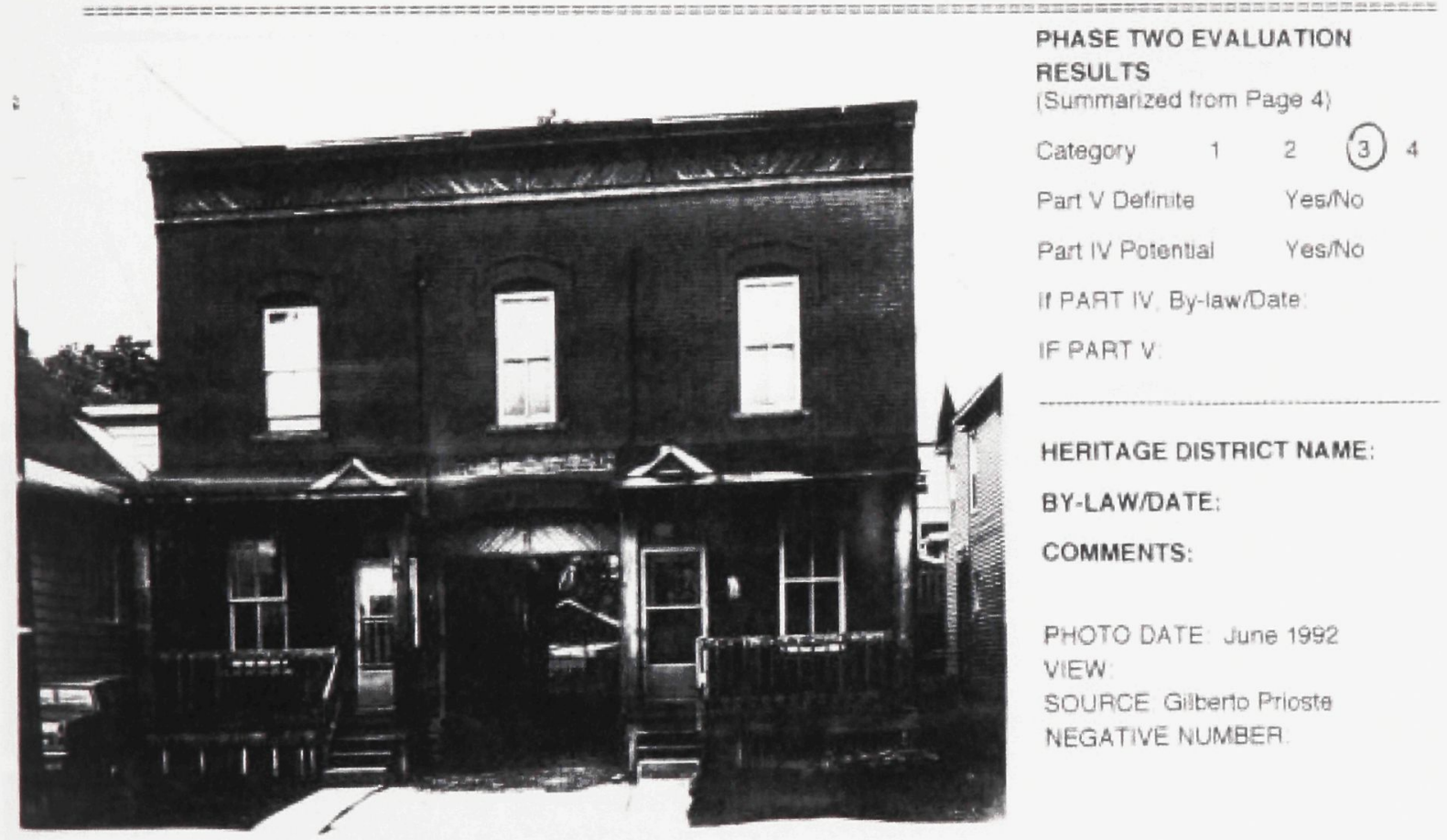

52-54 Bolton St 
CITY OF OTTAWA

DEPARTMENT OF PLANNING \& DEVELOPMENT COMMUNITY PLANNING BRANCH
HERITAGE SURVEY
AND
EVALUATION FORM
BUILDING FILE NO.

PD : 4300 Boltan 78-80

HERITAGE DISTRICT FILE NO $\mathrm{PD}$

Municipal Address: 78-80 Bolton Straet

Building Name

Legal Description:

Date of Construction 1876

Original Use: fesidential - double

Present Use: residential - double

Lot $W 1 / 2\llcorner .7$

Additions:

Original Owner unknown

Present Zoning: $H R=1$

Present Owner

Planning Area: Lowertown West

PHASE ONE SURVEY

Polential Significance Considerable Some $\quad$ Limited None

History

Pre-1878)

$(1878$ :0 1913)

(1914 10 1957)

( 1958 to 1992 )

(Date of Construction)

Architecture

Environment

$\begin{array}{ll}3 & 2 \\ 3 & 2\end{array}$

(Landmark or Design Compatibilty

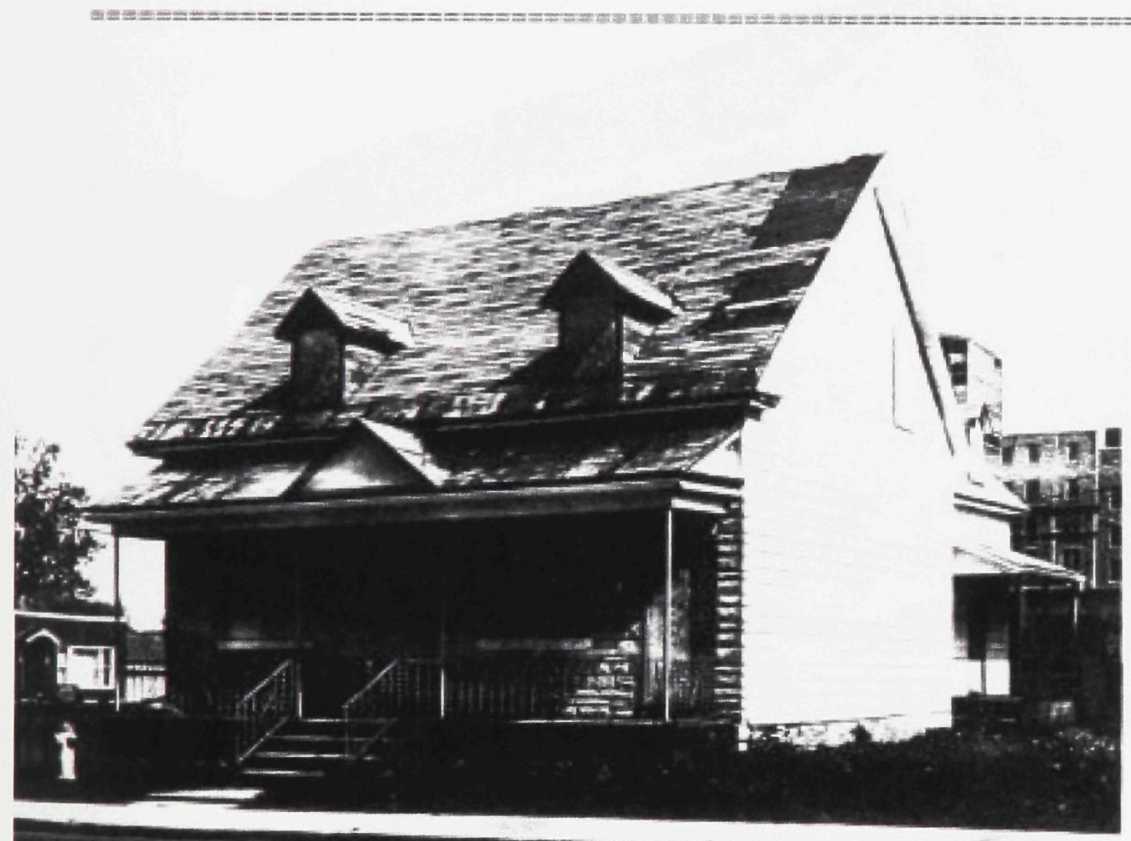

PHASE TWO EVALUATION RESULTS

(Summarized from Page 4)

Category

Part V Definite

(2) 34

YesiNo

Part IV Potential Yesino

If PAPT IV Bv-law Date

IF PART $V$

HERITAGE DISTRICT NAME:

BY-LAW/DATE:

COMMENTS:

PHOTO DATE: JUNE 1992

VIEW:

SOURCE Gilberto Prioste

NEGATIVE NUMBEA- 
CIPY OF OTfEN

DEPARTKEYT OP PLANEING I DERELPHEMT COMGUSITP PLAKREMG BRASCH
HBRIFGGB SURVEP
ANI

BVACUATIOS POAK
BDILDING PLLR 10

Pi 13:

HBNITAGR DISTHET PLLB Ho. PO $1392-5-1$ :

Musicioal dddeas: 2d1-283 untertand

\section{Buildiar Vane}

Legal Description: 352.30 WT!

Date of Cosatruction: $1881=16 ? 2$

Origioal Une: residentigh doplex

Present lat: residentiad

Preneat ZoBing: AH- 121

Plonaing Ares: Centeal Ites $\$$. E

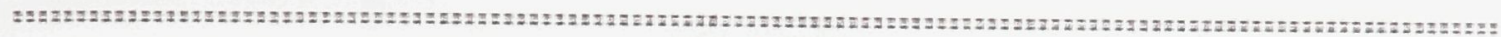
PBABB OHB SURVB!

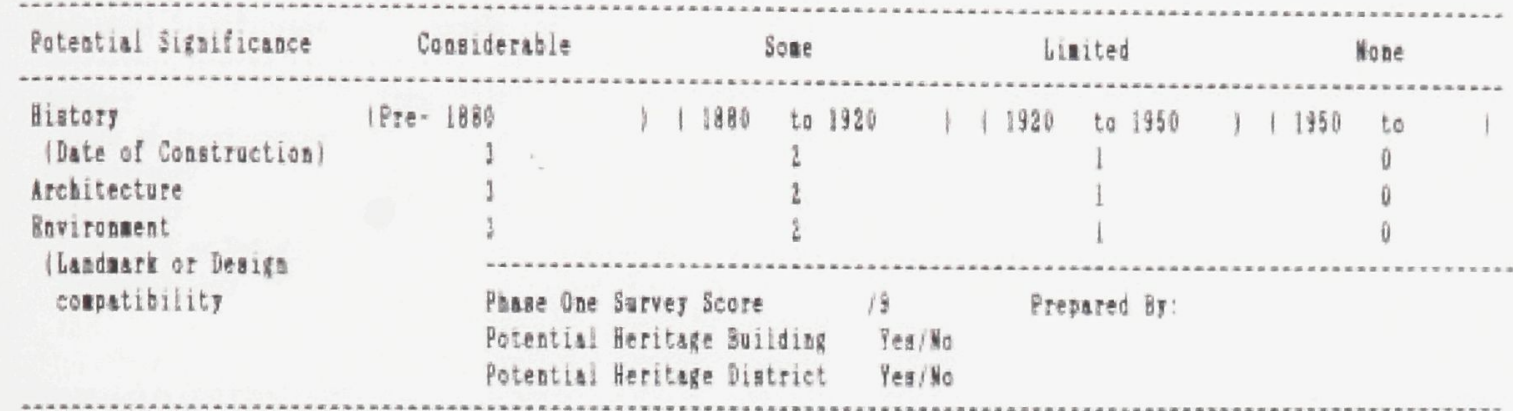

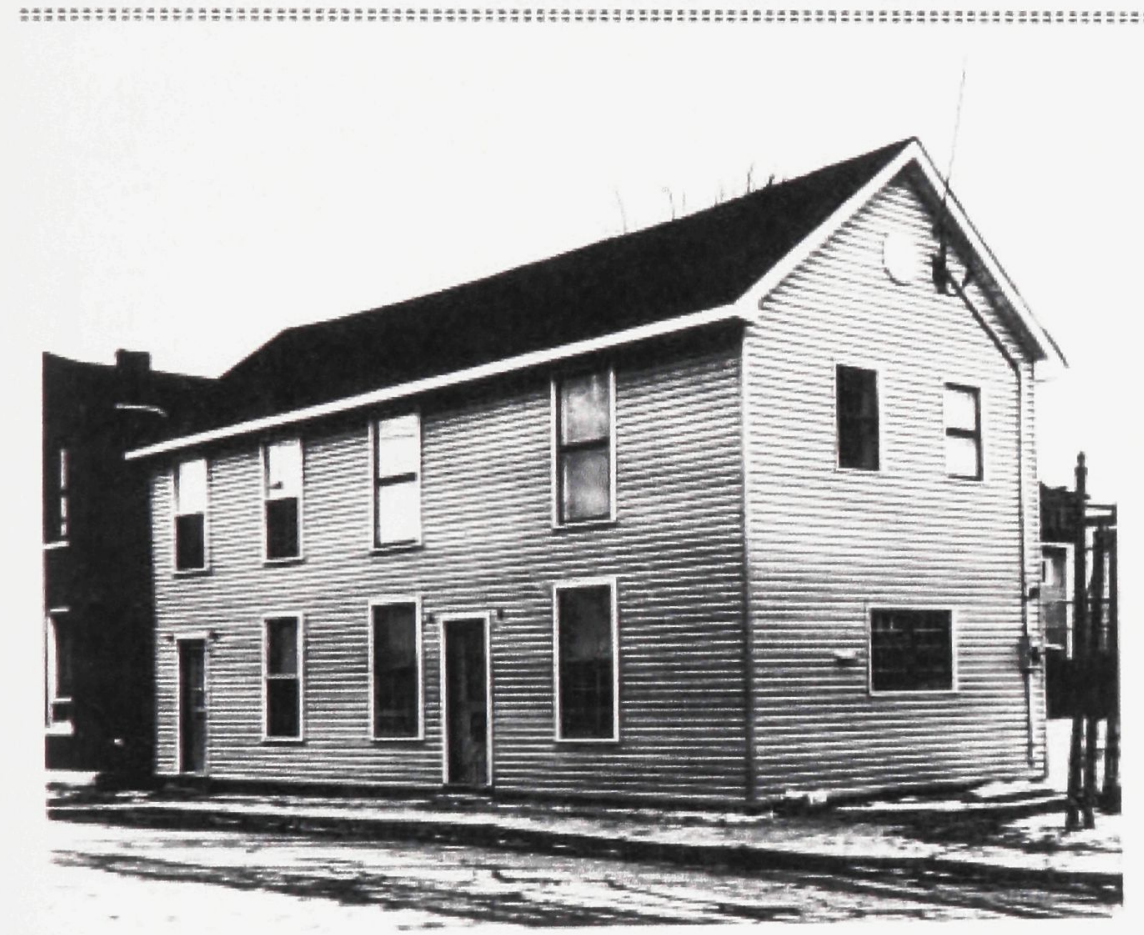

PHASB TWO BVALEATION RESEGTS

[Sunarized frou Pare i]

Category $1^{*} 2$ (J)

Part 7 Definite Tes/lo

Part If Patential les/Ho

If Paxt [V, 8y-1aw/Date:

IF PART $V$.

HBLIFAGE DISTHICP HAKE

Byvard Hareet

BP-LAV/OATE

Domarkis

Atsact buildise ohogog herat

PHOTO DATE: Jat lazO

VIRT

SOLPCB: Hs sease NEGATIYB KUIBSA: $1=-2$ 
Cift og OPfapa

OBPARYKEY OP PLAKEEMG + DERBLOPGEKT

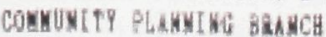

BRITAGB SURV?

anO

BVALATION FOEH

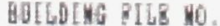

Po 13:

BBRITAGB DISPRICP FIL8 WD.

$904302-5-1:$

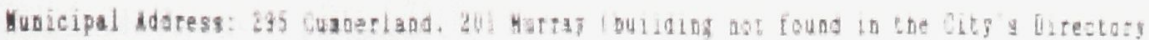
Buildiag Hase: vut badz'a Seocol
Legal Description: Na
Lot: If Block: 49
Plas
Date of Constructios: 1904
Aoditions
Ortgisal Ure: schoo
Origioal Oures: th Sef School Babed
Preseat Jge: vacad
Pregeat orner:

Present Loaing

Planiag Area: Centes Azed $Y, B$.

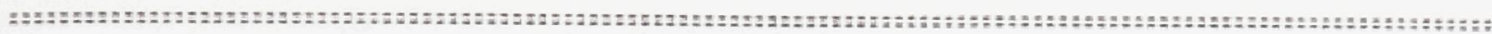

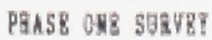

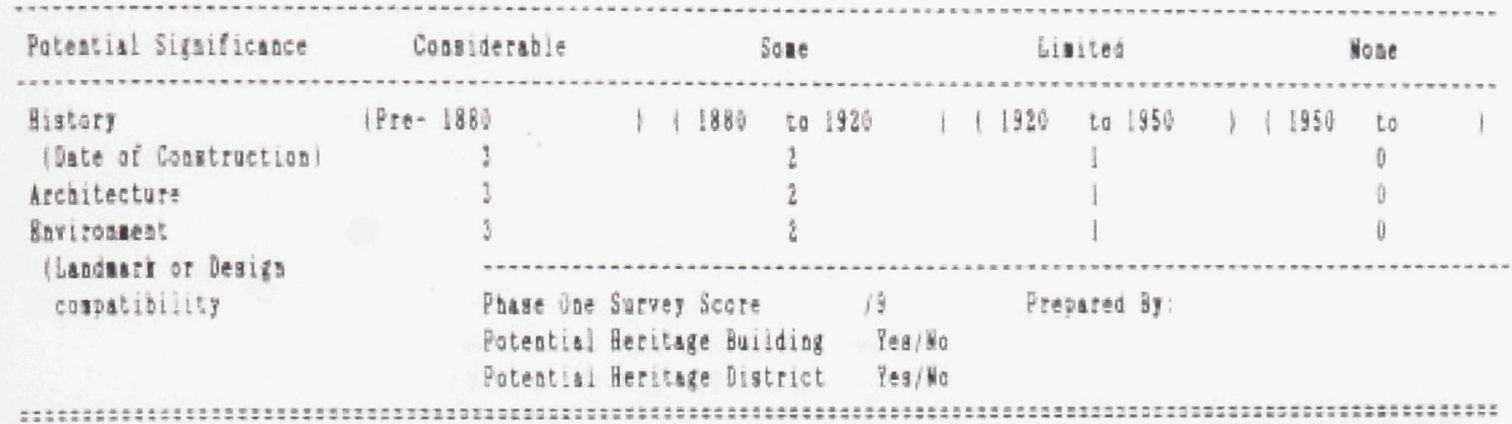

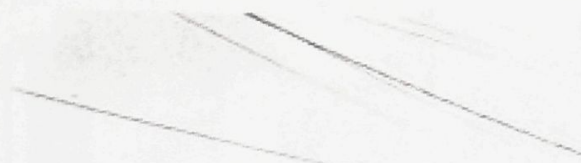

1

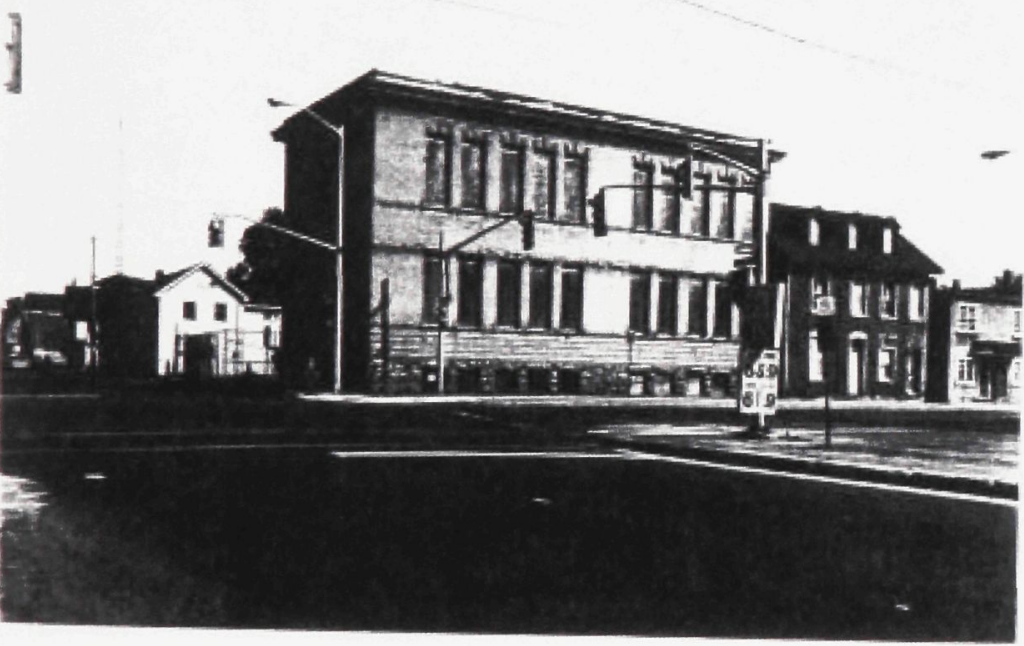

A:tach builotag pho:og hara

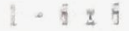

PHASB FNO BVALUATLOK RBSULTS

(Sumarited fror Page i)

Category 1 采 14

Part $Y$ Definite Tesiso

Puet IV Potedis! iegillo

If PRRT IV, By-lawidate:

If Pagi 7

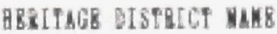

Gyourd hasept

$B T=4$ LN/DATS:

CoMEBST

PHOFO ONPE: JAD 19911

VIgY

800RC8: \# Senade

HBGATIVB NUEBBI: $49-2+$ is 
CIrT op ot?ana

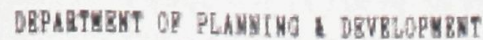

COKGUNITY PLANEIYG BRAKCH
HBaLTAGR SUDEBY

AND

BValuston POEX
BUILDIYG PILB w.

Pil 1):

GBRTAGB DESFRICA PLLB HO.

PQ 1 $1302-5-1$ :

Nubicipal Addregs: 207 - 209 hutray

Buildiag Kase

Lefal Description: W $1 / 2$ WS curza?

bate of Construction: sefore 1812 ar 1878

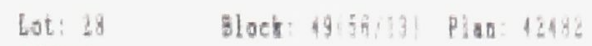

Orizina! Use: dooble regidence

Pegreat lise: double reqidescet

Additions:

Original Graer: 3. Hetrs

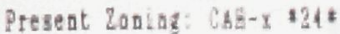

Present ovser

Plasnisg Ates: Cetrol hres Y. B.

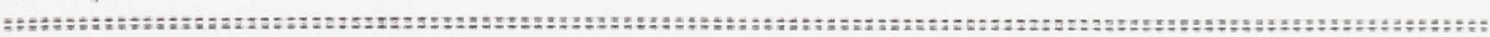

PHASB OKB SURVBY

Potential Sitoificance
Considerable

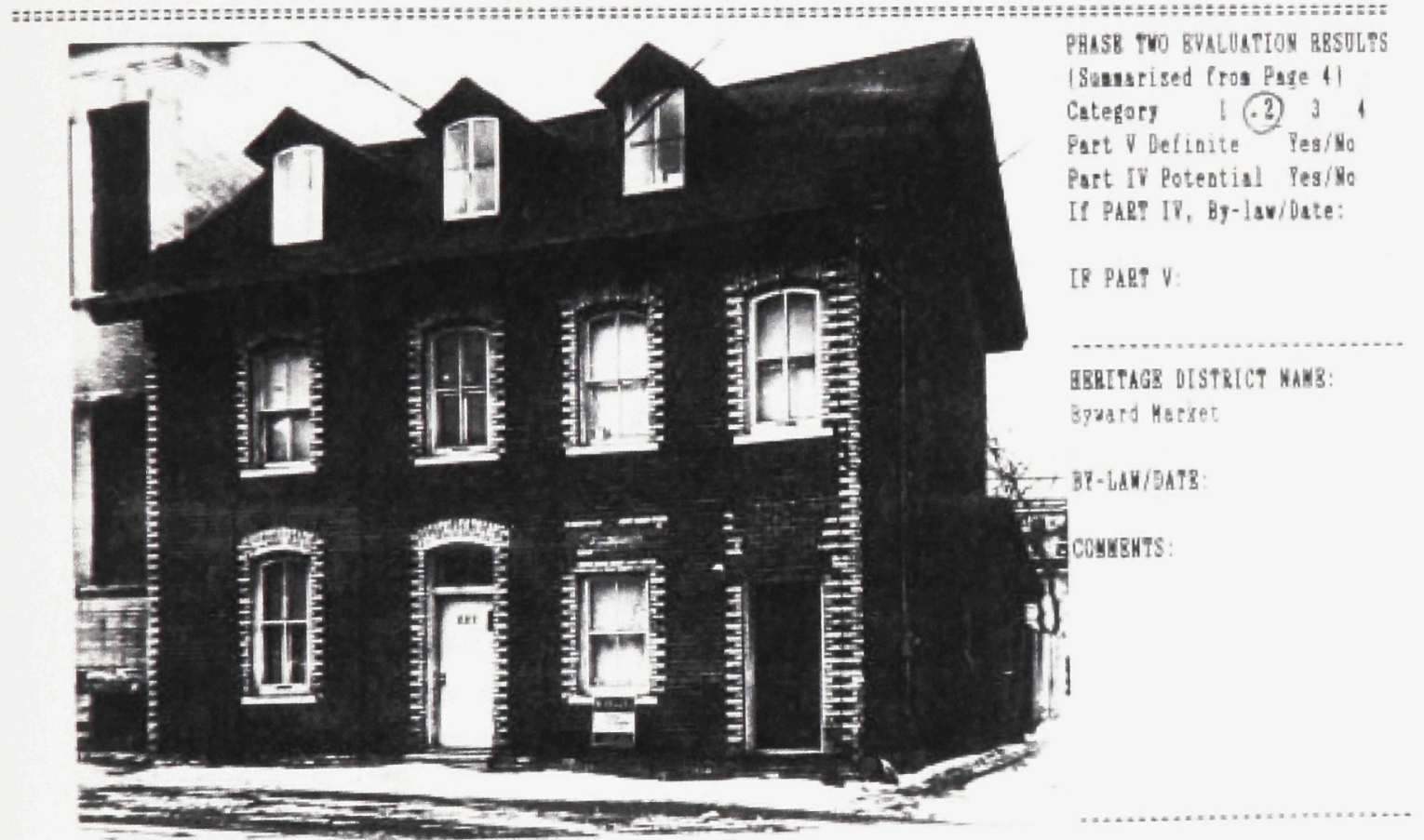

Artach bullataz shoted bete

PHoro DATR: ing 1980

$1-\frac{1}{1}$ मी

VIBV

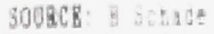

RBSATIVB NUYBSR: $49-4$ 
APPLICATION TO DEMOLISH FIVE BUILDINGS AT 52-54 BOLTON, 78-80 BOLTON, 281-283 CUMBERLAND, 287 CUMBERLAND AND 207-209 MURRAY STREET, DESIGNATED UNDER PART V OF THE ONTARIO HERITAGE ACT, LOCATED IN THE LOWERTOWN WEST HERITAGE CONSERVATION DISTRICT

DEMANDE EN VUE DÉMOLIR CINQ ÉDIFICES AU 52-54, RUE BOLTON, 78-80, RUE BOLTON, 281-283, RUE CUMBERLAND, 287, RUE CUMBERLAND ET 207-209, RUE MURRAY, DÉSIGNÉS EN VERTU DE LA PARTIE V DE LA LOI SUR LE PATRIMOINE DE L'ONTARIO ET SITUÉS DANS LE DISTRICT DE CONSERVATION DU PATRIMOINE DE LA BASSE-VILLE OUEST

ACS2005-DEV-APR-0098

DEFERRED FROM 12 APRIL 05 MEETING

RIDEAU-VANIER (12)

Ned Lathrop, Deputy City Manager, Planning and Growth Management (PGM), John Moser, Director, Planning, Environment \& Infrastructure Policy, and Stuart Lazear, appeared before the Committee with respect to departmental report dated 14 March 2005. Following a comprehensive presentation by Mr. Lazear, Councillor Bédard referred to a request to Committee of Adjustment (COA) to lift the overlay at 78-80 Bolton. Mr. Lazear advised that COA reserved their decision, but once a final decision is made, there is an Appeal period from that date (of 20 days).

The Committee heard from the following delegations:

Brook Burchfiel, Lowertown West Community Association, supported the staff recommendation. Heritage is an integral part of the neighbourhood. Mr. Burchfiel pointed out one of the buildings proposed for demolition is one of only six or seven carriage houses in all of Lowertown, which are quite unique and relate the fact that horse and carriages travelled these roads. These carriage houses cannot be destroyed since horse-drawn carriages currently travel the neighbourhood reliving the area's beauty and history. The building is in bad repair at the rear, but the woodwork can be seen, which is quite amazing since the building is 130 years old. He would prefer to preserve the façade. Almost $1 / 3$ of the block is contemplated for demolition with no replacement plans submitted. That is counteractive to what is intended for the downtown core. Our Lady's School is a grand old building and it was amazing that farther down the street, the Guigues School was remodelled and is now selling one-bedroom apartments for $\$ 274,000$; that is what can happen when these old schools are renovated in a positive manner. The community would like to see the value saved and maintained. The fact there are no replacement buildings does not follow the Heritage Act. His main point was that to allow for demolition of buildings that have been allowed to reach this stage of disrepair seems like a reward system for owners that mistreat the City's heritage and sets a bad set of circumstance. It is contrary to what the average Lowertown resident has accomplished to preserve the City's heritage. All the new buildings advertise potential residents to come down to "historic Lowertown"; then do not destroy historic!

In response to Councillor Bédard on 52-54 Bolton (the Carriage House), Mr. Burchfiel reiterated he would like to see heritage preserved first, but was aware that was not always possible. He did not have a problem with infill and development. Lowertown should be a vital living area, but the area heritage should not be disregarded or torn down, but preserved and maintained in some manner. Similarly with Our Lady's School, he did not have a problem with adding three storeys and at the back, but save the façade for future generations to appreciate. Councillor Bédard received confirmation Mr. Burchfiel's interest was in maintaining as much as possible without demolition.

Barbara Warren, Vice-Chair, Local Architectural Conservation Advisory Committee (LACAC), stated LACAC unequivocally did not support the demotions before PEC. She attended the lengthy presentation by the proponent's architect, structural engineer, lawyer and the proponent himself, at the 24 March LACAC meeting. Ms. Warren is a conservation carpenter living in Ottawa with significant experience working on older homes. Compelling arguments as to the deteriorated state of the buildings 
was neara, but she was not present to address the state of the buildings. LACAC supports the staff recommendation to oppose the demolitions, based on Ontario Heritage Act regulations and the numerous policies and guidelines approved by City Council that relate to heritage districts, as outlined and well laid out in the staff report before PEC. Suffice it to say, it is clearly not in the interest of City Council or PEC to approve the creation of vacant lots in Heritage Conservation districts. She did reiterate that LACAC strongly supports the tenants of the Ontario Heritage Act and specifically Section 42, Part 10, that gives Council the authority to refuse to issue a demolition permit until the owner has applied to Council under this Section and been given a permit to erect a new building on this site. There are huge development pressures in the Lowertown West Conservation District and every applicant that comes forward with a request to demolish a building in the district also comes forward with a plan for a replacement building and applies for a Building Permit according to the Act. There is good reason for the City to follow this procedure; it is the only way to ensure an accountable process is in place for providing appropriate, sympathetic replacement buildings in conservation districts. It also ensures there is a process to address whether demolition is the only option. Approval of these demolitions would effectively side step an important safeguard for the preservation of heritage buildings and districts. She asked why this applicant should be treated any differently than others that have come forward. As a result of this proposal she has learned some unfortunate realities about the inability of the City to require property owners to maintain their properties. Minimum standards only apply to buildings that are occupied. There are no maintenance requirements for vacant buildings, so long as they are secured and the site is kept relatively free of debris; vacant buildings can simply be left to deteriorate. LACAC sees this fact as a huge problem for the preservation of heritage resources in the City. A number of the buildings before PEC today have been owned by the proponent for many years and, as a professional, she questioned how the buildings arrived at this state if proper maintenance had been undertaken. In conclusion, approving these demolitions would be a dangerous precedent. PEC must not set this precedent by supporting the demolition of these buildings.

Meg Hamilton, Council of Heritage Organizations of Ottawa (CHOO/COPO), supported the comments by Ms. Warren and the staff recommendations to refuse the application to demolish the heritage buildings

Arnell Goldberg, Solicitor for the applicant Claude Lauzon, pointed out there are five separate and distinct applications and asked PEC to make its decision based on each separate application. The applicant has been placed in a very difficult position in being asked to obtain a building permit without knowing he will be allowed to demolish the building. Each building, except for one, is in a state of disrepair. The applicant proposes, in each case, to construct a building for rental purposes only (not a condominium) and will comply with existing zoning by-laws, subject to appropriate application to the COA. He is not attempting to overreach in any way and is trying to comply with OP requirements to provide rental housing in the central area. Mr. Lauzon had a Demolition Order on the School Board building some 10 years ago and did not comply with the order; in fact, he sued the City to get a building permit. It was only after he initiated the work that he found it was impossible to do so. At the time, he had intended to build a rental project, which he still wishes to do. Unfortunately, it now has to be a new building in compliance with the directions over the heritage district.

Claude Lauzon, applicant, grew up in Lowertown, on Bolton, in the same block as two of the buildings. In 1960 he moved to New Edinburgh and continues to live in the same home. He enjoys living in the heritage district and understands all that it implies and would like to maintain these districts. But, there are some properties that cannot be renovated and that is why he was before PEC today. He purchased his first building in 1954 in Lowertown and has purchased many since. When he purchased 52-54 Bolton in 1973, it was in disrepair, but he kept the tenants. The tenant in 52 moved out a few years later; whereas the tenant in 54 remained until 1990. As the properties became vacant he did not re-lease them since they were in such disrepair. He would like to reproduce the building with new material build to today's specifications, fire and building codes. He would like to keep the Carriage House, which held sentimental value. 
ne purchased $/ 8-80$ Bolton in 1988, which was a vacant property, also in disrepair. He purchased it because he owned the property next door and for land purposes only. He wanted to construct a four storey rental building, with parking below ground to avoid parking on the street. He purchased the school property in 1981 as a result of a foreclosure. It was a good building and he had high hopes to build six loft apartments, three regular apartments and one bachelor. He applied for a building permit in 1996 and in the winter of 1998/99 the roof caved in under the weight of the snow. In the spring, he hired a roofer to rebuild the roof. In 2002, he was awarded a building permit, but when the building was entered it was found that two floors had collapsed under the weight of the roof and brick. The building was determined to be beyond repair. In 1981/83, he purchased the building next door on Cumberland; it was a well kept, rented building. He asked for demolition to construct a better building on the entire site since the building footprint is $33 \times 50$; it will allow for underground parking and be compatible with the environs. In 2003, he purchased 207-209 (for land value only) after a fire to increase the development potential and allow for parking. Again, all the buildings are not designated heritage although they are located within a heritage area. He owned several properties in Lowertown and New Edinburgh, all of which are in a good state of repair and rented.

Based upon the submissions by Mr. Goldberg and in response to Councillor Bédard, Mr. Lazear explained there was a process for review and approval of replacement or new construction under the Ontario Heritage Act in a Heritage Conservation District. The process does commence with concept plans and evolves to the point where staff is either satisfied or not to come forward to LACAC, PEC and Council with a recommendation to both demolish the building and approve the replacement building. In terms of approving an appropriate replacement or partial replacement building or the retention of a façade of one building and the incorporation of new buildings behind, that is a process for discussion within the context of concept drawings and review by the public by LACAC, PEC and Council. Responding further, Mr. Lazear explained that when a formal action report is presented for review and approval by LACAC, PEC and Council, the design has evolved to a close to final stage. But, concept drawings for applications have also come forward to LACAC for their discussion and review for projects before a formal application has been submitted with final drawings.

Bob Jardine, Cleland Jardine Engineering Ltd., Structural Engineer for the Applicant, provided written submissions that outlined his findings relative to the structural condition of each of the buildings and potential for salvaging the existing buildings. That information was circulated to the Committee and is held on file with the City Clerk.

In response to Councillor Hunter, Mr. Jardine remarked that the building structures will not improve over time and he could negate any further discussion by stating that all of his presentation regarding the four properties will come to the same conclusion, that from a structural perspective, they have all deteriorated to the point where re-construction is not a cost-beneficial or practical alternative on any of the four in question.

Councillor Bédard explained he was intimately familiar with this matter and although the applicant had expended considerable sums in the process to date, he had been advised to approach the heritage planners at the beginning of the process. Having said that, many of the proposals are in fact very much needed in the Ward; in particular, the proposal for Our Lady. That school had considerable historical significance in the area, but unfortunately has deteriorated through the years. That entire block is very interesting since it is located beside the Shepherds of Good Hope, at the corner of Cumberland and Murray, and begs to be re-developed. The proposal at the time was very interesting and it is unfortunate that it fell through. The owner does want to build anew and that is something he would encourage. Mr. Goldberg had suggested the owner would like some assurance that if the owner comes forward with plans, that PEC and Council will permit demolition, but that is not the question today. The question is really one of process. Staff, in his experience, has been excellent in giving advice and making suggestions with considerable discussion at LACAC relative to preliminary plans. In fact, many architects and owners have come forward on many occasions before proceeding or before there 
is tne entertanment of the demolition or revamping of a vacant lot in a heritage area. The process does not allow the City to grant a demolition permit when no plans are presented. He suggested staff work closely with the owner to arrive at some accommodation on the concept plans for each of the properties since he was aware the owner did want to redevelop the properties.

Mr. Lathrop stressed principles and policies in a Heritage Conservation District need to be carefully adhered to and concern given when buildings are proposed to be demolished as to what replaces them. Care must be given to buildings when they can be saved; and, if they cannot be saved, that they be replaced appropriately. It is a process, as the Councillor stated, that is important to be followed and staff is asking that it be followed.

Correspondence from David Flemming, Heritage Ottawa, in strong support of the staff recommendation, was circulated and is held on file with the City Clerk. The Committee approved the recommendation.

That the Planning and Environment Committee recommend Council:

1. refuse the applications to demolish heritage buildings located within the Lowertown West Heritage Conservation District, received on February 27, 2005 for 52-54 Bolton Street, 78-80 Bolton Street, 281-283 Cumberland Street, 287 Cumberland Street, and 207-209 Murray Street

2. refuse to issue a demolition permit for 52-54 Bolton Street, 78-80 Bolton Street, 281-283 Cumberland Street, 287 Cumberland Street and 207-209 Murray Street, until the owner has applied for and been given a permit to erect a new building on the site (Ontario Heritage Act, R.S.O. 1990, Chapter.18, Section 42.10). 